Portland State University

PDXScholar

$1-1-2012$

\title{
Reexamining the Global Cold War in South Africa: Port Usage, Space Tracking and Weapons Sales
}

Rebecca Nicole Eisenberg

Portland State University

Follow this and additional works at: https://pdxscholar.library.pdx.edu/open_access_etds Let us know how access to this document benefits you.

\section{Recommended Citation}

Eisenberg, Rebecca Nicole, "Reexamining the Global Cold War in South Africa: Port Usage, Space Tracking and Weapons Sales" (2012). Dissertations and Theses. Paper 117.

https://doi.org/10.15760/etd.117

This Thesis is brought to you for free and open access. It has been accepted for inclusion in Dissertations and Theses by an authorized administrator of PDXScholar. Please contact us if we can make this document more accessible: pdxscholar@pdx.edu. 
Reexamining the Global Cold War in South Africa:

Port Usage, Space Tracking, and Weapons Sales

by

Rebecca Nicole Eisenberg

A thesis submitted in partial fulfillment of the requirements for the degree of

\author{
Master of Arts \\ in \\ History
}

Thesis Committee:

Friedrich Schuler

Patricia Schechter

Jennifer Tappan

Martha Works

Portland State University

(C)2012 


\begin{abstract}
The global Cold War is used frequently by historians to frame the context of political, economic, social, military, and geographical history of the $20^{\text {th }}$ century. This is often the case in Africa as well. This thesis set out to explore U.S.- South African relations during the 1960s. After conducting research in the State Department Records (Record Group 59) of the National Archives from 1967-1973 three case studies emerged that suggested that reexamination of how historians traditionally view U.S.-South African relations during this time period is necessary. The three case studies include U.S. use of naval ports in South Africa, the strategic geographic location of South Africa and its importance to NASA's satellite and missile tracking stations, and the policy of selling of weapons to South Africa by the U.S. While this is by no means an exhaustive study of this time period due to limited time in the National Archives, it does offer promise for more research involving this topic.
\end{abstract}




\section{Acknowledgements}

The author wishes to express her utmost gratitude to Dr. Friedrich Schuler. His guidance, encouragement, patience, flexibility, and high expectations made this experience invaluable to the author not only as a master's candidate, but as an aspiring historian.

The author also wishes to thank her husband, Cooper Brown, friends, fellow teaching colleagues, and family who offered an immeasurable amount of support during this long journey. An extra thank you deservedly goes to the author's mother and father who challenged and supported her to be better in all things academic and beyond. 
Table of Contents

Abstract....................................................

Acknowledgements.....................................ii

Introduction.............................................

Chapter One: Cold War Context.............................16

Chapter Two: USS Franklin Delano Roosevelt...................43

Chapter Three: Tracking Stations............................77

Chapter Four: Weapons Sales to South Africa...................121

Conclusion............................................. 163

Bibliography........................................... 168

Appendix A: Timeline of South African History.................175

Appendix B: Operation Mayibuye...........................178 
"The story of the defeated is part of the truth and texture of those harried years." Piero Gleijeses

\section{$\underline{\text { Introduction }}$}

The Cold War was permeated with many interactions between the U.S. and the international community, particularly with what was then called the Third World. South Africa would be no different. However, rather than reacting to the direct threat of Soviet or communist influence, the U.S. government saw South Africa an essential launch point for its Navy and for its space program making the United States act sympathetically towards the white apartheid government. During the 1960s and early 1970s there are three episodes that provide for a revealing examination of the U.S. government's foreign policy towards South Africa in the context of the global Cold War. These three episodes include the docking of the USS Franklin Delano Roosevelt in 1967, the use of satellite and missile tracking stations in Johannesburg by NASA from 1960-1973 and the arms embargo as instituted by Kennedy and carried out by Johnson and Nixon from 19631970. These case studies, as examined in the U.S. National Archives, suggest that a reexamination of how the U.S. government made decisions in relation to the South African government, particularly in the context of the global Cold War and in the face of apartheid, is necessary in order to accurately appreciate the dynamic factors shaping how the United States interacted with the international community during this important chapter in World History.

The South African government was not the perfect ally in the global Cold War. Their implementation of apartheid was a risk for the U.S. government because they could be accused of having friendly relations towards a government that employed such an 
abhorrent method of controlling its population. However, largely because of its colonial history and geographical location, South Africa possessed technologically developed ports for space and sea that were of high importance to the U.S. Therefore, the U.S. government, specifically the Executive branch, was repeatedly forced to evaluate what type of relationship they wanted with the South African government and how best to achieve a delicate equilibrium both domestically and internationally.

The global Cold War was a complex and dynamic era for the United States. It was a war of two political and ideological systems. It was an economic war against socialism and communism. It was a political endeavor to keep dominoes from falling. It was a nuclear, military, and scientific development race against the Soviets. It was a geographic race for who could dominate non-aligned states economically and politically. The global Cold War was not always a reaction to the fear of Soviet influence; rather, the U.S. did act on the fear of communism spreading, such as in South East Asia. This is an important distinction to make because in the case of South Africa, the U.S. government was more concerned about communist influence, rather than Soviet influence domestically, and used South Africa as a base to fight Soviet influence in other arenas, such as the space race. For the purposes of this paper, most of these aspects will be looked at, however the space race, intervention geographically and economically of newly independent states, and the fear of the spread of communism, rather than the Soviet influence, will be focused on when proving the thesis that U.S. relations with South Africa were driven by the global Cold War, but not necessarily from fear of immanent Soviet intervention in the area. 
Within the vast scholarship on U.S.-South African relations during the Cold War, the three case studies examined for this thesis are only briefly mentioned. Although far greater attention has been given to apartheid, only a handful of scholars have specifically looked at the implications of apartheid on U.S.-South African relations during the presidencies of John F. Kennedy, Lyndon B. Johnson, and Richard M. Nixon. Thus this thesis fills a significant gap in the historiography on U.S. foreign policy toward South Africa during this period of the global Cold War. Rather than fitting U.S.-South African relations into the mold of a traditional Cold War definition, as previous historians on the subject have done, this thesis examines three significant events in U.S.-South African history that illustrate the complexities of foreign policy decisions the U.S. government, the Executive branch specifically, made in context to South Africa, their government, and the global Cold War. It illuminates the dynamic layers that allowed these decisions by the U.S. Executive branch to happen and permits the influence of geographical, political, and economic considerations, along with media perception and complexities between the different branches of the U.S. government to play a role in understanding the complex relationship between the U.S. and South African governments.

Thomas Borstelmann focused largely on the U.S. government's relationship with apartheid. Borstelmann's early work primarily attended to the early years of the Cold War and the effect of the National Party coming to party in 1948 on U.S. diplomacy towards South Africa. He synthesized the cohesion of economic and strategic interests the U.S. government had towards South Africa with the onslaught of the Cold War and the start of the Civil Rights movement. Borstelmann argued: 
An examination of American support for the white minority government of South Africa and for the colonial rulers of the rest of southern Africa offers a window on the complicated interplay of two major themes of twentieth-century American history: racism and anticommunism. ${ }^{1}$

According to Borstelmann, southern Africa became a testing ground for the U.S. to see if it could create a multiracial alliance with the then-called Third World against the Soviet bloc. Borstelmann stated:

In its pursuit of the preoccupying goals of containing communism and preserving the 'free world,' the Truman administration provided critical assistance to the reassertion of white authority in southern Africa after World War II. The United States acted, in sum, as a reluctant uncle- or godparent- at the baptism of apartheid. $^{2}$

Borstelmann argued that the Truman administration did not trust the black South Africans to maintain a Soviet-free zone in South Africa, which was essential to the U.S. for a variety of reasons, most notably for the amount of raw resources they had. Borstelmann argued that Truman's racism did not help matters, especially when Afrikaner nationalists freely lumped all serious opponents of apartheid together as "communists" because Truman did not think to question the claim seriously. ${ }^{3}$ In sum, Truman felt his options were limited in who to support in South Africa against the spread of Soviet influence and therefore went with the option that he felt was the best for the U.S. at that time.

Borstelmann also confronted the cohesion of U.S. racial politics with its diplomatic relations with a special emphasis on southern Africa; however his later work covered 1945-1990 globally, rather than just the early Cold War in southern Africa.

Borstelmann focused on the effect of racial policies in the U.S. with the concern that

\footnotetext{
${ }^{1}$ Thomas Borstelmann, Apartheid's Reluctant Uncle: The United States and Southern Africa in the Early Cold War (New York: Oxford University Press, 1993), 4.

${ }^{2}$ Ibid, 197.

${ }^{3}$ Ibid, 201.
} 
"Soviet leaders had begun to show greater interest in expanding their influence south of the Mediterranean. The [U.S.] concluded that any encouragement of racial strife 'would enhance Sino-Soviet Bloc opportunity in Africa." ${ }^{, 4}$ Kennedy was of special concern to Borstelmann. He found that Kennedy's policies towards South Africa would remain in place through Johnson and Nixon's presidencies. His main policy consisted of choosing "staunchly anti-Communist white rulers" over the ANC or PAC, despite fears of how the U.S. civil rights movement might react. ${ }^{5}$

Borstelmann was not alone in assuming that U.S.- South African relations during the 1960s and 1970s was largely driven by fear of Soviet influence and communism spreading to a strategic ally in southern Africa. Robert Kinlock Massie approached the U.S.-South African relationship in the context of how apartheid impacted U.S. organizations with ties to South Africa, such as churches, universities, private businesses, civil rights leaders, and various leaders within the U.S. government. For the purposes of this thesis, his research on U.S. government policy was most intriguing. He portrayed the government as one that was divided: U.S. presidents were too concerned with the implication of the importance of South Africa as an ally during the Cold War to make any significant changes of policy towards apartheid. More specifically, he argued:

...the Americans also became convinced that a revolution would open the door for a Communist takeover or a superpower confrontation over the southern sea lanes and the world's largest supply of gold. They read with alarm the CIA reports that Communists had infiltrated the African National Congress.... The lens of the cold war thus altered- and sometimes distorted every intelligence or

\footnotetext{
${ }^{4}$ Thomas Borstelmann, The Cold War and the Color Line: American Race Relations in the Global Arena (Cambridge: Harvard University Press, 2001),136.

${ }^{5}$ Ibid, 170.
} 
policy analysis, casting suspicion on all acts of resistance against colonialism or apartheid. ${ }^{6}$

While Massie's focus is not necessarily on why the U.S. Executive branch conducted governmental relations with South Africa in the manner it did, he does presume that communist expansionism, led by the Soviets, in South Africa was the framework for governmental decisions and therefore acted as a catalyst towards positive change in favor of black South Africans.

Massie is not alone in his assumption that the Cold War was the rationale behind decisions being made in Washington. Christian M. De Vos was a bit more moderate on the influence of the Cold War on U.S. presidents, Kennedy in particular. He argued, “...Kennedy simultaneously affirmed the legitimacy of the apartheid government, not because the Cold War left him no other choice but because that was the only choice his administration was willing to see. ${ }^{7}$ De Vos structured his historical analysis of U.S. decisions being guided by the overblown assumption that the apartheid government was the only choice for an ally in the Cold War among rival South African political parties because they were the safest choice in the ideological war against the spread of communism.

J.E. Spence adjusted the lens and looked at the overall role of South Africa to the west throughout the Cold War arguing their importance to thwarting communism:

Yet ultimately, South Africa's projected image as the 'bastion of the free world' failed to convince Western policy makers. Their skepticism was based on the argument that what the Soviets sought by projecting naval power in distant waters

\footnotetext{
${ }^{6}$ Robert Kinlock Massie, Loosing the Bonds: The United States and South Africa in the Apartheid Years (New York: Doubleday, 1997), 128.

${ }^{7}$ Christian M. De Vos, "Balancing Acts: John Kennedy, The Cold War and The African National Congress," Politikon 32, no. 1 (May 2005), 119.
} 
was political influence rather than the means to provoke military confrontation with the West.... Western governments recognized that in the improbable event of a shoot-out in the southern oceans, the Republic's anti-Communist posture would leave it little choice but to place its ports, harbours, and military facilities at the West's disposal. ${ }^{8}$

Spence's claims approached a much more accurate depiction of the rationale behind maintaining a working relationship with the South African government in stating its importance to the U.S. militarily and geographically. However, he failed to develop a historical narrative that supported his assertions, leaving his rationale open for further investigation.

There was clearly a tendency in the literature dealing with U.S.- South African relations during this time period to emphasize the role of either the communist threat (often embodied in opposition parties to apartheid) or the fear of the spread of Soviet influence. Historians have not devoted much, if any, time on the specifics that created this historical context. Too little investigation has been done on the papers, speeches, and communiques in the Executive branch that would explain why this assumption is correct.

There is a much smaller collection of literature about Soviet- South African relations during the Cold War. Much of the work done on Soviet-South African relations during the Cold War is minimal and speculative due to documentation limitations.

However, Vasili Mitrokhin and Christopher Andrew did a significant amount of historical research using archival materials snuck out of the former Soviet Union by Soviet archivist Mitrokhin. Focusing on the push to engage Sub-Saharan Africa in the Cold War, Andrew and Mitrokhin paint a picture of a cash-strapped Soviet Union attempting to stay ahead of the curve as former African colonies gained independence. A major tool

\footnotetext{
${ }^{8}$ J.E. Spence, "Southern Africa in the Cold War," History Today 49, no. 2 (Feb 1999), 46.
} 
of the Soviet Union was to engage in distributing forged letters to African leaders that were "designed to strengthen their suspicion of the United States and their trust in the Soviet Union."

Andrew and Mitrokhin did look briefly at the Soviet's interaction with the ANC and SACP. More specifically, even though Moscow had "only modest expectations of the prospect of national liberation movements" in South Africa, they did feel that it was important to maintain relations with the groups that opposed apartheid and might ultimately come to power should there be a revolution. Regardless of giving the ANC and SACP modest funding ( $\$ 300,000$ a year to the ANC), Andrew and Mitrokhin argued that "the first fifteen years of Umkhonto operations posed no significant threat to South African apartheid regime." This was largely due to the mass exile and imprisonment of ANC and SACP leadership. ${ }^{10}$

Vladamir Shubin analyzed the causes of armed conflict in Southern Africa during the Cold War. While most of his work focused on Angola, Mozambique, Zimbabwe, and Namibia, he has produced a minimal amount of scholarship on South Africa. His research drew from ANC archives and interviews with both Soviets and South Africans. Shubin offered more depth in the Soviet involvement with the ANC and SACP than Andrew and Mitrokhin. Via interviews with men involved, Shubin retold how 328 Umkohonto fighters were trained by the Soviets in Odessa from 1963-1965. The Soviets attempted to teach them guerilla tactics that might be useful should they rise up against apartheid. Training continued for the next two decades, but was spotty and

\footnotetext{
${ }^{9}$ Christopher Andrew and VasiliMitrokhin, The World Was Going Our Way: The KGB Battle for the Third World (New York: Basic Books), 438.

${ }^{10}$ Ibid, 443.
} 
unsustainable, as the Soviets could not get the ANC supplies needed should an armed uprising happen. They also could not get the fighters back into South Africa. ${ }^{11}$ Much of the rest of the work offered by Shubin focused on post-1976 Soviet-ANC relations. However, his book did offer a much more detailed relationship between the Soviets and the ANC and SACP.

What is concerning about the work conducted on Soviet- South African relations during the time period is that much of the work focuses either on pre-WWII or post-1976 relations between the Soviets and various political parties in the South Africa. What does exist during the time period of this thesis is information that is often contested by scholarship done in the area, as demonstrated by Shubin and Mitrokhin and Andrew's work. Theses authors have similar research stated but drastically different interpretations of events. Scholarship tends to be minimal in this realm because of the limitations on resources available, as stated by both sets of authors in their work.

Soviet involvement in South Africa was further complicated by Cuban interaction with sub-Saharan Africa, thus illustrating that the communist front was not always united during the Cold War. Andrew and Mitrokhin only briefly mentioned Cuba by saying that their government saw that region as "“imperialism's weakest link."” 12 Cuba clearly had an interest in emerging governments after colonialism began collapsing, thus begging the questions of whether or not they were influential in South Africa and if so, to what extent. Piero Gleijeses offered answers to this. While much of his work focused on Algeria, the Congo, and Angola, he did spend some time examining South Africa. While this thesis

\footnotetext{
${ }^{11}$ Vladimir Shubin, The Hot "Cold War": The USSR in Southern Africa (London: Pluto Press, 2008), 244245.

${ }^{12}$ Andrew and Mitrokhin, 433.
} 
does not emphasize Cuba's role in South Africa, they are pertinent to the conversation because they help frame the context to which the Soviets were involved with South African politics. Using a variety of archival work from the U.S., Cuba, Belgium, and the U.K., Gleijses argued that it was Cuba's interest in spreading a revolution throughout Africa that was far more concerning to the U.S. government than Soviet intentions. ${ }^{13}$ Although he offered little insight to U.S.- South African governmental relations prior to 1976, it did offer a different view of the Soviet Union in Africa. There was an attempt to spark a leftist revolution, but it was led by Cuba, not the Soviet Union, and it happened not in South Africa, but in Angola, the Congo, and other former Portuguese and Belgian colonies.

There are a significant amount of scholarship that offers comprehensive histories of the Union of South Africa and South Africa. Leonard interpreted events involving South Africa on the world stage during the time period of this thesis. Drawing from a wide array of South African historiography that embodied post-Cold War and postapartheid perspectives, Thompson set out to reexamine major historical themes in South African history that may be more pertinent and inclusive of voices that were largely quieted by apartheid. ${ }^{14}$ Although his work was largely a domestic history of South Africa, he did contextualize historical events in relation to the Cold War. Thompson argued that South Africa was never a high priority for the Soviets. Proof for Thompson was that top leaders of the ANC- Nelson Mandela and Oliver Tambo- were not

\footnotetext{
${ }^{13}$ Piero Gleijeses, Conflicting Missions: Havana, Washington, and Africa, 1959-1976 (Chapel Hill: The University of North Carolina Press, 2002), 8-9.

${ }^{14}$ Leonard Thompson, A History of South Africa, Revised Edition (New Haven: Yale University, 1995), xiixiii.
} 
communists and therefore were never seriously courted by the Soviets. For Thompson, a more important relationship was that of the U.S. and Great Britain with the South African government because they wanted to invest in mineral resources and open trade.

Thompson did not connect this interest to the Cold War context. ${ }^{15}$

Sue Onslow and John Daniel made strong arguments about U.S.- South African relations during the Cold War that resonate throughout this thesis. Onslow edited a collection of works by various authors, including Shubin, Onslow, and Daniel. Onslow's intent was to allow for a more complex and holistic picture of South Africa during the Cold War to emerge via recent studies conducted. She argued that the Cold War was not a bipolar contest between the U.S. and the USSR. Rather:

The region therefore must be seen as an integral part of the 'international civil war' of the twentieth century, as the battle between 'centre-right and left' interacted with the politics and militarization of the struggle in Southern African region, as the discourse of liberalism and arguments for evolutionary, socioeconomic change were effectively sidelined. ${ }^{16}$

Onslow argued that South African politics during the Cold War cannot be oversimplified by fitting it into a traditional definition of the Cold War. By incorporating chapters on U.S. nuclear aspirations and Soviet military involvement, Onslow established the importance of South Africa and its government to the U.S. and, to a lesser degree, the Soviet Union during the Cold War.

John Daniel, who was featured in Onslow's work, had a similar argument to Onslow. He argued:

\footnotetext{
${ }^{15}$ Ibid, 216-217.

${ }^{16}$ Sue Onslow, "Introduction," Cold War in Southern Africa: White Power, Black Liberation, ed. Sue Onslow (New York: Routledge, 2009), 1-2.
} 
Similarly misguided was the enveloping of apartheid's mission in the Cold War cloak. At the end of the day, the Cold War paradigm was a myth. This is not to suggest that its arch-advocates like Botha and Malan did not sincerely believe in it and that they were fighting the West's good fight. They did. However, wrapped up as they were in this profound misconception, it blinkered them from the realities of the South African struggle. For the apartheid regime, the Soviet Union was never the real problem. ${ }^{17}$

There is proof in documents and press clippings that showed they fully believed that they were essential to the west's military and political strategies against the threat of Soviet aggression. Much like Spence, Onslow and Daniel do not spend a significant amount of time in their work developing the actual history that guided their arguments about U.S.South African relations during the Cold War during the time period reflected in this thesis. This thesis seeks to fill that hole in the scholarship.

The scholarship available on U.S.-South African relations from Kennedy to Nixon is often minimal and presumptuous, frequently used to paint a larger picture of the Cold War in Africa. To my knowledge, there is no literature that hones in on smaller events that shape a more detailed understanding of U.S. relations with the South African government in an effort to define how South African history fits into the global Cold War particularly during the 1960s and early 1970s. Rather, specified history embodying South African- U.S. governmental relations during the Cold War tend to emphasize historical chapters such as mineral security and the proliferation of nuclear knowledge. The history of port usage for ships, space stations, and weapons sales begs us to admit to the historiographical account another means of inquiry that will further clarify South Africa's position in the global Cold War.

\footnotetext{
${ }^{17}$ John Daniel, "Racism, the Cold War and South Africa's Regional Security Strategies 1948-1990," Cold War in Southern Africa: White Power, Black Liberation, 51.
} 
This thesis is based on previously unavailable and unconsidered primary sources from the U.S. National Archives Record Group 59, records of the State Department. This record group was selected because of its preeminence in secondary literature consulted prior to a visit to the U.S. Archives in Maryland. More specifically, files from the broad categories of Communism, Defense, and Political Affairs and Relations from 1967-1969 and 1970-1973 were consulted. In addition to these materials, the primary source series Foreign Relations of the United States, the analyst papers of the CIA, and the Congressional Record were all consulted for further information. From these collections, the three case studies emerged as the pre-eminent issues concerning the U.S. Executive branch as they appeared often in the document collections for both the Executive and Legislative branches. They also drew a significant amount of attention from the media when searched in the New York Times and London Times historical databases.

Presidential policy between the 1960s and the 1970s was largely favorable to the South African government. Kennedy, Johnson, and Nixon all dealt with various crises that challenged their international image thanks to allying themselves economically and politically with South Africa. Despite the potential for bad press and backlash from the Civil Rights community in the United States, they all felt it necessary, if not vital, to stay aligned with the South African government, as they were invested deeply economically, scientifically, and militarily. Arms embargoes were put into place and broken with conventional weapons continuing to be sold thanks to loop holes in the embargoes. Port policies were established, scrutinized, and ultimately disregarded in an effort to maintain access to air and naval ports. Even NASA was brought under the microscope because their policies upheld apartheid policy in order to keep access to satellite and missile 
tracking stations essential to landing men on the moon. Kennedy, Johnson, and Nixon all legitimized their actions by claiming that keeping South Africa close politically would allow for some sort of influence on their apartheid policy. Whether or not they actually believed this is debatable.

There is no doubt that global Cold War politics did heavily influence major foreign policy decisions for Kennedy, Johnson, and Nixon. But, to what extent did it influence policy choices towards South Africa? This paper will argue that the global Cold War did provide a back drop to decisions made, although it was not to fight the direct threat of the Soviet influence within South Africa's borders. Access to minerals, ports, and tracking stations were vital to global Cold War efforts. Also, selling weapons to beef up the South African Defense Force's capabilities can be contextualized in the global Cold War framework. However, the U.S. did not decide upon such actions to keep the Soviets at bay in South Africa. Also, the U.S. did not base their policies towards South Africa on the fear of South Africa becoming communist via banned groups such as the ANC and PAC, as was argued at the time.

Onslow and Daniel both suggested in their work that the way in which historians look at relations during this time period should be re-examined, but then do not offer specifics to support this idea. The three case studies that emerged from doing research in Record Group 59 allow for the actual re-examination to occur. These case studies are broken up and examined within the pages of this thesis. Chapter one, while serving largely to contextualize South Africa in the global Cold War context, will introduce the importance of South Africa on the stage of the larger global Cold War. This chapter will focus on Cuban- African relations during the 1960s and spread of communist influence 
within domestic South African opposition parties, such as the ANC. Chapter two looks at the first case study involving port usage by U.S. naval ships in South Africa and the difficulty the various branches of the U.S. government had in making a cohesive port policy in the face of the global Cold War and apartheid. Chapter three discusses the impact of the port policies that emerged during the 1960s on NASA's use of bases in South Africa to support a man landing on the moon. Chapter four analyzes the decisionmaking process and the importance surrounding the sale of U.S. weapons to South Africa in the face of growing aggressive apartheid policies. It is through these three case studies that a common theme of apprehension and lack of clarity emerges, thus bringing to question the manner in which historians have previously looked at U.S.-South African relations via the global Cold War lens.

Because U.S. policy was often contested between Congress and the White House, it is historically significant to separate the decisions, statements, and opinions of the various branches of government. Even within branches, such as the Executive branch, there is discussion and disagreement about the way in which to proceed when making policy. This illustrates the curious advance of a dynamic policy between major government players within branches and between the branches. 


\section{Chapter One: Cold War Context}

There is deeper historical context that must be explored when looking at South Africa and the U.S. during the global Cold War. Decisions made by the Executive branch of the U.S. government were undoubtedly influenced by the global Cold War pertaining to South Africa, but South African policy was more complex than the simplistic east versus west struggle. This chapter will look at the traditional view of South Africa being a territory where the U.S. battled the Soviet Union economically and politically and expand the view to that of the global Cold War. South Africa was a naval region with ports to fight the global war elsewhere, such as in Vietnam but also in outer space.

There are three major historical camps concerning communism in South Africa. The first camp argues that communism did not exist in South Africa or if it did that it was irrelevant. The second argues that communism did it exist and its importance is of relevance when studying domestic and international South African history. The third argues that communism's presence is of great importance and overshadows much of how South African domestic and international interactions are viewed. I am of the second camp. While communism did exist and was definitely of concern for the apartheid

government, especially communism's connections to major opposition parties such as the ANC, it should not overshadow how all South African history is viewed from 1958-1973.

\section{U.S. and the Global Arena:}


In Europe in the post- World War II setting, Greece and Turkey both threatened to become communist and possibly under the guise of the Soviets during their civil wars. ${ }^{18}$ This resulted in the U.S Executive and Legislative branches declaring and passing the Truman Doctrine and Marshall Plan. For that purpose they promised diplomatic and economic aid to countries that could potentially fall to communist governments, not necessarily to Soviet influence.

In 1950, there were major revolutions in Guatemala and Cuba. The CIA and Executive branch, reacted with intensity using assassination attempts and attempted coups. In 1954, Guatemala endured "Operation Success": the U.S. army deployed propaganda such as strategically placed pamphlets, along with diplomatic pressure, that forced Jacobo Arbénz Guzmán out of power. His policy of reclaiming unused land by the United Fruit Company, a U.S. corporation, and giving it to the landless population was not tolerated. After a successful revolution in Cuba, the Soviet Union placed and activated nuclear weapons on Cuba and pointed them at the U.S., resulting in the Cuban Missile Crisis. After the removal of the missiles, the U.S. Executive branch made it a priority to eliminate Fidel Castro from power, but ultimately failed to do so.

Within this context, it is necessary to mention the Bandung Conference and the challenge of nationalist rejection of an emerging bi-polar world order. To simplify the global Cold War as such would be to ignore the split that happened in April 1955 at the Bandung Conference. This meeting was the first time that the decolonizing world, namely those in Africa and Asia, came together to attempt an establishment of a unified

\footnotetext{
${ }^{18}$ William R. Keylor, The Twentieth Century World and Beyond, $5^{\text {th }}$ ed. (New York: Oxford University Press, 2006), 239-240.
} 
voice that would transcend nationalistic categorizations. ${ }^{19}$ Its purpose was to confront anticolonialism, disarmament, and development despite Cold War developments in Southeast Asia. ${ }^{20}$ This acted almost as a tertiary element that complicated the idea of east-west relations because, despite China's attendance (the Soviet Union did not attend), there is a veritable split between what the U.S. viewed as allied states in the global Cold War. The Bandung Conference is significant because not all perceived eastern states were aligned in the context of the global Cold War; rather they made their own political attempts at creating a unity for themselves despite China and the Soviet Union.

Most notably, the U.S. then expanded activity to with the former French colony Vietnam, after it earned independence in 1954. Vietnam's independence coincided with the Chinese communist revolution and the Korean War. Upon Vietnam's independence and the popularity of socialist- oriented Ho Chi Minh, the U.S. became increasingly concerned that the conversion of governments to communism was a trend, rather than isolated incidents; thus, the domino theory was born. All branches of the U.S. government vehemently opposed the spreading of communism in Southeast Asia and began investing itself politically, economically, and militarily as early as Truman's administration. It joined British and French efforts as global Cold War allies.

Kennedy and Johnson's military intervention in Vietnam no doubt cast a shadow on major international decisions elsewhere in the world, including those made towards South Africa. In that global strategic concept port availability in South Africa was crucial for troop and material movement to and from Vietnam. It is in that context that

\footnotetext{
${ }^{19}$ Jason Parker, "Cold War II: The Eisenhower Administration, the Bandung Conference, and the Periodization of the Postwar Era," Diplomatic History 30, no. 7 (November 2006), 870.

${ }^{20} \mathrm{Ibid}, 872$.
} 
troops aboard the USS Franking Delano Roosevelt returned from Vietnam in February 1967 and needed to refuel and allow the troops leave time for their sound mind. The policy originated out of a naval policy context, not a political context. There was little concern in the Executive branch that the South African government, or Africa in general, was going to fall like dominoes to communist or socialist governments as it was feared in Asia. Also, the number of countries gaining independence in the 1960s from colonial rule in Africa was not a motivating factor.

The Middle East was also an area of concern for the U.S. and the Soviets. In relation to the thesis of this paper, the Suez Canal crisis would be cause for concern by the U.S., particularly in relation to their ability to ship goods and move military should they need to do so. The leader of Egypt, Gamal Abdel Nasser, envisioned a Pan-Arab empire from the Atlantic to the Persian Gulf under his leadership. In pursuit of this goal, Nasser understood the importance of working within the confines of the global Cold War. Therefore, he took to playing the U.S. and Soviet Union off of one another to create a more viable economic and political empire in the Middle East. In 1955, he secured a pledge of military supplies from the Communist bloc to help equip the Egyptian army. From the U.S. and Great Britain, he received financial assistance amounting to $\$ 70$ million for his construction of a new dam at Aswan which would allow for land cultivation and the production of hydro-electric power. $^{21}$

On July 20, the U.S. government, who had becoming increasingly agitated with the reliance of Nasser on military aid from the Soviet bloc and their anti-Israeli sentiments towards the recently formed state, withdrew their offer to help build the

\footnotetext{
${ }^{21}$ Keylor, 274.
} 
Aswan Dam. This ultimately led to the nationalization of the Suez Canal, which had just recently come under their full military control with the relinquishing of British military protection on June $13,1956 .^{22}$

The Soviets were not very active with the region until the 1970s; however, they did interact in the context of the various Arab-Israeli wars. Egypt, while not communist, courted the Soviet influence heavily for arms, particularly during the 1967 and 1973 wars with Israel. The scramble for what was then called the Third World was in full effect by the U.S. and, to not as intense of a degree, the Soviets and Chinese. Africa was no different.

\section{U.S.-South African Relations 1949-1960:}

In a CIA political assessment written on January 31,1949 , it is evident that the U.S. regarded relations with South Africa to be vital, but not because of the global Cold War. In fact, both the U.S. and the Soviet Union had a strong dislike for apartheid as established by Jan Smuts and expanded by Daniel F. Malan. "In the wider field of international affairs South African intransigence on the racial issue and on the control of colonial areas has provoked criticism from non-Soviet as well as from Soviet sources, and has made the country something of a propaganda liability to the US and the Western bloc." 23 The reality was that South Africa was vital to the U.S. because of its geographical position and it possession of key minerals vital to the Cold War effort. The CIA felt that supporting the South African government was important because it

\footnotetext{
${ }^{22}$ Ibid, 276-277.

${ }^{23}$ Central Intelligence Agency, “The Political Situation in the Union of South Africa,” 31 January $1949,1$.
} 
contributed to "order and stability in the whole of Africa." In addition, it had a naval base that was strategic for travel to Asia, as proven by use of the Cape Route during WWII. It also had an untold amount of industrial potential that could be beneficial to U.S. private industry. ${ }^{24}$

Maintaining access and positive political relations with the South African government, in theory, should not have been a problem for the U.S. As the CIA noted, "Politically, the Union's orientation is unquestionably toward the West." 25 Competition from the USSR should have been minimal to non-existent. The white-dominated government was fully on the West's side. However, the nine million "non-Europeans" who were repressed by apartheid served as a possible inroad for communists:

The genuineness of many of the native grievances provides an excellent opportunity for Communist agitation.... Though the failure of the natives up to now to develop any effective indigenous leadership or to come together in trade unions indicates that the political danger point is still some distance off, continued Communist failure to acquire significant influence can by no means be assumed. ${ }^{26}$ In a thirteen page report addressing the concerns, assumptions, and predictions about the future of South Africa, only one paragraph is spent on the threat of communist expansion into the country. This is an important indicator as to the concern for communist expansionism, as 1949 was the start of the red threat with over bloated McCarthyism and the discovery of the Venona Cables in the U.S. with realpolitik guiding many policy decision made by Truman and Eisenhower in the early years of the Cold War.

In November 1950, the CIA published another report on South Africa. In this report, the CIA was more concerned with the implications of apartheid on the image of

\footnotetext{
${ }^{24} \mathrm{Ibid}, 3$.

${ }^{25}$ Ibid, 3.

${ }^{26} \mathrm{Ibid}, 13$.
} 
the U.S., being their economic and political ally. Image was, of course, very important in the global Cold War, as propaganda and perception were as much a major part of the Cold War as the space and arms races. "The Malan Government's foreign policy is... a serious embarrassment both to the US and the UK." More specifically, "International resentment directed against the Union is greatly intensified by the harshness with which Malan's Government has preached and practiced its racial program of apartheid...."27 The CIA's report was hypercritical of apartheid, but recognized the strategic importance of South Africa.

The 1950 report repeated and expanded on the same points as the 1949 report. It too noted the economic, geographic, and military importance of South Africa to the U.S. Conditions were favorable for the west to maintain a Soviet-free situation for foreign policy decisions, saying, "It is an intensely anti-Communist government, but one also permeated with certain strongly anti-democratic tendencies." 28 Apartheid was the biggest liability with concern to possible Soviet penetration into the political system. "Apartheid is also a ready-made invitation for propaganda from the Communist bloc directed against both the Union and the countries associated with it." Regardless of the possibility of a Soviet threat in the form of being an anti-apartheid force for the racial majority, the U.S. found itself unable to "disavow a country so firmly within the Western camp as South Africa is." 29 The U.S. did recognize the possibility of a ready-made communist revolution in the form of anti-apartheid groups representing the non-white population, but

\footnotetext{
${ }^{27}$ Central Intelligence Agency, "South Africa Politics and US Security," 17 November 1950, 1.

${ }^{28}$ Ibid, 3 .

${ }^{29}$ Ibid, 8-9.
} 
it was not so imminent that it should trump the positives that came from maintaining a relationship with the South African government.

The 1950 report is one of the earliest reports to comment on the size of the military, which would balloon throughout the 1960s and 1970s thanks to the U.S., France, and U.K. selling them massive amounts of conventional weapons. Should governments in the west choose to do so, weapons sales and industrial development "would make it more useful to the US and UK in its time of war." More specifically:

In military matters the government has been favorably disposed towards cooperation with the US and UK as part of its efforts to modernize the obsolescent South African defense forces. The usefulness of this cooperation is limited, however, by the Union's small military budget, its preoccupation with internal security, and by political meddling with the armed services aimed at making Afrikaner elements dominant. ${ }^{30}$

The South African government started their weapons sales requests as early as 1950, asking the U.S. to sell them B-29 bombers for the intended purpose of defending Africa from the Indian Navy. The U.S. looked favorable on this because they were helping as much as they could, given they had a miniscule defense force, in the Korean crisis. The South African government also pled with the British government to help build up their navy to help defend the Cape Route and to build up naval yards that would be helpful in wartime for the U.S. and U.K. should they need it. ${ }^{31}$ These sales would be difficult for the U.S. to deny because of its strategic location.

It is important to expand on why the South Africans were concerned about the Indian Navy. Throughout the 1950s and 1960s, KGB operations did increase in India. ${ }^{32}$

\footnotetext{
${ }^{30} \mathrm{Ibid}, 2$.

${ }^{31}$ Ibid, 7.

${ }^{32}$ Andrew and Mitrokhin, 313.
} 
The Indians did have a regional alliance with the Soviet Union, not as partners in the Soviet revolution, but as two states that had mutual interests, such as being opposed to the new Chinese government after the revolution. ${ }^{33}$ India also acted as a natural alliance with the Soviet Union because the U.S. relied on Pakistan as a "strategic counterweight to Soviet influence in Asia," thus encouraging the Indian government to look elsewhere. ${ }^{34}$ The KGB did consider their relationship with India a success because of their continued alliance throughout the global Cold War against the U.S. and her allies in Asia. By the 1970s, the KGB had its largest presence outside of the Kremlin in India and felt that they were successfully influencing elections via putting in officials that remained sympathetic to the Kremlin, not because of the spread of communism. ${ }^{35}$

The Indian Ocean itself was an important zone to control in global war because it was essential to trade, served as a geographically important alternative to using the Suez Canal, and allowed ease of access to Eastern Africa, which saw colonial powers withdrawing throughout the $1950 \mathrm{~s}$ and $1960 \mathrm{~s}^{36}$ If one were to look at a map of states bordering the Indian Ocean, they would see U.S. and Soviet bases along the coast line, with the U.S. having bases in Mogadishu, Mombasa, Diego Garcia, and Berbera, among other areas. The Soviets held bases in Mauritius, Seychelles, Socotra, and Aden. ${ }^{37}$ Regardless, the Indian Ocean was seen as being a "zone of peace" probably because the threat of actual war was too great to conceive by the superpowers.

\footnotetext{
${ }^{33}$ Vojtech Mastny, “The Soviet Union’s Partnership with India,” MIT Press Journals, 13 June 2011, www.mitpressjournals.org.

${ }^{34}$ Andrew and Mitrokhin, 314.

${ }^{35}$ Ibid, 320-321.

${ }^{36}$ Raymond W. Copson, "East Africa and the Indian Ocean- A Zone of Peace?," African Affairs 76, no. 304 (Jul. 1977), 341-342.

${ }^{37}$ Oyo Ogunbadejo, “Diego Garcia and Africa’s Security,” Third World Quarterly, 4, no.1 (Jan 1982), 105.
} 
By 1952, the CIA added an additional importance to South Africa- access to strategic minerals, which was essential not only in the arms race sector of the global Cold War, but the economy as well. South Africa had the potential to produce a substantial amount of chromite, manganese, and uranium, all vital elements for the U.S.'s Cold War machine. ${ }^{38}$ In fact, $1 / 4$ of the west's total manganese and chromite supply came from South Africa at the time, along with its entire supply of amosite asbestos. In addition, South Africa provided large quantities of corundum, antimony, gold and industrial diamonds to the west. ${ }^{39}$

Despite its economic potential, its military was still considerably small and needed to be built up. It was "undermanned, poorly trained, and inadequately equipped." The military budget only constituted $2 \%$ of the nation's total budget for 1952 . CIA analysts were concerned about this because, despite their weakness, they had “considerable military potential." They had proved themselves worthy of Western support during WWII and continued to be helpful to the West by sending what they could to the Middle East to support the British in their affairs there and to Korea to support the war. The CIA saw enormous potential in their naval, air, and port facilities, which would "be of considerable value in event of general war, as in World War II, especially if the Suez Canal were denied the West." The bases could be utilized for ship and aircraft maintenance in route to conflict. In addition, the staging and deployment of submarines from South Africa could be crucial during wartime. ${ }^{40}$

\footnotetext{
${ }^{38}$ Central Intelligence Agency, "Probable Developments in the Union of South Africa," 20 October 1952, 1. ${ }^{39}$ Ibid, 2 .

${ }^{40}$ Ibid, 2.
} 
The 1952 CIA report did discuss the potential for a communist invasion via antiapartheid forces. It puts a little bit more urgency on the threat of communism in the form of non-white leadership, but it did not feel that it was an imminent threat. "Though Communist progress will not be swift among the mass of the Natives, the Communists may have greater success in acquiring positions of leadership among the Native organizations." The reason for its slow encroachment was that there was a lack of organizers, distrust of communist leaders by the masses, and an absence of organized tactics by the international community for successful intervention. ${ }^{41}$

All three CIA reports mentioned have two things in common. They all mention the strategic importance of South Africa in the context of war, should there be another World War, which has already been demonstrated. They also all mention the concern for potential embarrassment against the U.S. given the growth of apartheid and their reliance on the government at the same time. The blooming nature of apartheid did happen to correspond to the gradual reliance of the west on South Africa for military and economic needs.

The 1948 elections in South Africa were pivotal. With the election of Malan, the National Party took control and kept its tight grip on it until 1994. The National Party was the major proponent of the installation of apartheid for economic and political control by the white minority population. ${ }^{42}$ With the National Party came swift and fierce implementation of apartheid. In 1949, they passed the Prohibition of Mixed Marriages Act of 1949, which is self-explanatory. In 1950, they passed the Group Areas

\footnotetext{
${ }^{41}$ Ibid, 6 .

${ }^{42}$ Iris Berger, South Africa in World History (New York: Oxford Press, 2009), 114.
} 
Act, which confined people of different races to segregated areas and would act as the predecessor to the Bantustans. This law saw the increase in humiliation of the non-white population by enforcing such acts as the "pencil in the hair" test which deemed how African an individual was and consequently where they should live. ${ }^{43}$ In 1953 , the Bantu Education Act was passed, which brought school education and teacher training under control of the Department of Native Affairs. Prior to this, schools had been run by church and mission programs. Now, the state controlled education, which meant that the non-white population saw their level of education plummet. By 1970, 34.8\% of urban Africans and $63.4 \%$ of rural Africans had no education. ${ }^{44}$

The racial policies of apartheid came to head via the Sharpeville Massacre on March 21, 1960. By 1960, the white population owned $88 \%$ of the land, despite only constituting $15 \%$ of the population. ${ }^{45}$ Sharpeville was essentially a peaceful protest against stringent pass laws that kept the non-white population confined to certain types of jobs for limited wages based on the Bantustan they lived in. Essentially, they could not get a job without a pass. They could not get a pass without living in a Bantustan. They could not live in a Bantustan without permission from the government. They were forced to move onto Bantustans in order to get jobs. At the protest, the South African police opened fired and killed 69 people. The government also responded by banning the ANC and PAC. The West was disturbed by the media images that came out of this incident and responded. In April 1960, the U.S. Executive branch moved to put apartheid

\footnotetext{
${ }^{43}$ Robert Kinlock Massie, Loosing the Bonds: The United States and South Africa in the Apartheid Years (New York: Doubleday, 1997), 21.

${ }^{44}$ Charles H. Feinstein, An Economic History of South Africa: Conquest, Discrimination and Development (New York: Cambridge University Press, 2005), 158-159, 161.

${ }^{45}$ Christopher Coker, The United States and South Africa, 1968-1985: Constructive Engagement and its Critics (Durham: Duke University Press, 1986), 1.
} 
permanently on the Security Council's agenda. They also set up a selective arms embargo. ${ }^{46}$ Despite the arms embargo and being under constant scrutiny for its domestic policies, the National Party continued its brutal enforcement of apartheid. Between 19601980, the black population living on Bantustans grew from $39.8 \%$ to $53.1 \%$.

Consequently, there was also a sharp increase in the number of black South Africans living in shanytowns, an equivalent to Hoovervilles during the Depression. ${ }^{47}$

It is questionable as to why the U.S. was motivated to implement an arms embargo, which would then by followed by a UN-wide embargo. In 1960 a rash of new African states joined the UN. ${ }^{48}$ Did the U.S. support an arms embargo because it morally opposed the massacre of 69 people at Sharpeville? Or, did they want to appeal to the newly formed/ future independent states of Africa? J.E. Spence argues that the U.S. supported an arms embargo to keep the Soviets from capitalizing on its anti-colonial image in the UN and prevent the advancement of a Soviet- Third World alliance within the General Assembly. ${ }^{49}$ This may be true, but the reality was that South Africa carried a significant amount of importance economically and militarily and could potentially overpower any of the newly formed states in southern Africa. This could explain why South Africa recovered very quickly economically and politically from Sharpeville. In the 1960s, it saw a 6\% growth economically thanks for foreign investment largely from the west. $^{50}$

\footnotetext{
${ }^{46}$ Ibid, 5-6.

${ }^{47}$ Berger, 132.

${ }^{48}$ J.E. Spence, "Southern Africa in the Cold War," History Today 49, no. 2 (Feb 1999), 44.

${ }^{49}$ Ibid, 44.

${ }^{50} \mathrm{Ibid}, 45$.
} 


\section{Cuba in Africa:}

In 1960, sixteen European colonies- French, British, and Belgian- all gained independence in Africa. The U.S. State Department's and Executive branch's response, according to Piero Gliejeses, was to see Africa as the next "battleground." More specifically, it feared the new countries' immaturity and resentment towards the west, which would then offer opportunities for political, economic, and military penetration by the east. ${ }^{51}$ But, the reality was that the U.S. could, and did, offer a significant amount of reliable economic aid. Little did they know that the most direct challenge to their authority in sub-Saharan Africa would come not from the Soviets or the Chinese, but Cuba.

In 1961, Khrushchev and the KGB approved a new and aggressive campaign to revamp their global strategy pertaining to the so-called Third World. Rather than focusing on the newly independent African states, they chose to focus on Latin America. The Cubans configured their own revolutionary policy targeting Africa. Che Guevara was "convinced that sub-Saharan Africa was 'imperialism's weakest link." ",52 Whereas the Soviet relationships with new African leaders in places such as Algeria and Ghana remained weak, the Cubans sought to create a sustainable relationship. ${ }^{53}$ For example, in 1963, Castro sent a group of 29 doctors, three dentists, fifteen nurses, and eight medical technicians to Algeria. ${ }^{54}$ This would be the first of multiple trips that happened

\footnotetext{
${ }^{51}$ Gleijeses, 5-6.

${ }^{52}$ Andrew and Mitrokhin, 433.

${ }^{53}$ Ibid, 434.

${ }^{54}$ Gleijeses, 36.
} 
throughout the 1960s. ${ }^{55}$ In addition to medical aid, the Cubans also gave Algeria military aid, which would be repeated in other countries throughout Africa. Congo and GuineaBissau would also benefit from this aid. ${ }^{56}$

One of the biggest areas of concern for the U.S. was Zanzibar. In 1962, Cuba paid for eleven Zanzibaris to travel and train in Cuba. They returned in 1963 to Zanzibar. The U.S. was very fearful that Cubans were trying to turn Zanzibar into a communist state. Being that they had little intelligence available from the country, the U.S. feared the worst, which included that they could serve as a base for insurgency operations from Kenya to the Cape, all of which was friendly towards to the U.S. It would also serve as a propagated example of what a successful African socialist state could look like. If the Cubans were successful there, there was no telling how far the ripples of success would travel in Africa. However, the reality was that Cuba was never able to spark any sort of a revolution and the State Department concluded that there was no Cuban influence in Zanzibar. In fact, by February 1963, Zanzibar joined with Tanganyika, a non-communist state, to create Tanzania. ${ }^{57}$

The Congo (formerly known as Zaire) would be the next unstable country that was cause for concern by the U.S. State Department. The Congo had been of high interest to the U.S. for material reasons- namely that the Congo had uranium for nuclear bombs and the U.S. wanted it. ${ }^{58}$ Belgium, the Congo's former colonial power, lost their control of the Congo when a referendum was held in June 1960 for independence. The

\footnotetext{
55 Ibid, 38.

${ }^{56}$ Ibid, 53-54.

${ }^{57}$ Ibid, 59-60.

${ }^{58}$ Jonathan E. Helmreich, United States relations with Belgium and the Congo, 1940-1960 (Cranbury: Associated University Presses, 1998), 46.
} 
Belgians tried to maintain their control over the armed forces and mineral resources, much to the dismay of the new government of Patrice Lumumba. Lumumba wanted the wealth to benefit the Congolese. U.S., British, and Belgian investors were all very worried. Thus, the Belgian government created a crisis in the Katanga region of the Congo. Lumumba asked the UN for help to keep the Katanga region from deteriorating into warfare. The UN relented, possibly because of U.S. interests being at stake. The U.S. then became intertwined by supporting Joseph Mobutu in an effort to "stabilize" the country and thus, played a significant role in the downfall and assassination of Lumumba. ${ }^{59}$ Che watched the U.S.'s reaction and decided that they should intervene militarily. He assembled a squadron of 113 black Cubans to fight in the Congo. ${ }^{60}$ After seven months of fighting and training in the Congo, Che finally realized that they could not make significant progress toward a general revolution and they withdrew, but not before causing alarm to the U.S. about the spreading Cuban influence in sub-Saharan Africa. $^{61}$

The Cubans were not finished after their failure in the Congo. Cuba found relative success in Guinea-Bissau, a Portuguese colony that was fighting for independence. While the country had hostility among its ethnic groups, they remained united in fighting against the 20,000 Portuguese soldiers. They called the Castro government for assistance and it answered. ${ }^{62}$ By 1967, Cuba had inserted nearly 60 doctors and military advisers. They also provided military aid. Guinea-Bissau benefitted

\footnotetext{
${ }^{59}$ King Leopold's Ghost, Linden Productions, Inc., 2006.

${ }^{60}$ Ibid, 89.

${ }^{61}$ Ibid $142-143$.

${ }^{62}$ Ibid, 185-186.
} 
greatly from the strategic disbursement of aid, knowledge, and medical care. ${ }^{63}$ By 1973 , Portugal had left Guinea-Bissau and independence had been declared. However, there is evidence that from 1966-1972, the Soviets had also given Guinea-Bissau aid in the fight against the Portugal empire. The question is, to what extent did Cuba act independently or did they spark fires that the Soviets needed to tend to. While there is little evidence that directly speaks to it, it was probably a joint effort begun by the Cubans and completed by the Soviets, not to be outdone by their revolutionary brethren. ${ }^{64}$

The longest Cuban intervention would take place in Angola; however this happened in the mid- to late- 1970s, outside the immediate scope of this thesis. With that being said, the U.S. did know about Cuban intervention, albeit on a relatively small scale, throughout Africa. Castro's pattern of intervention did start in north Africa and ultimately would work its way down to southern Africa, which was concerning to the U.S. The South African government, a steady ally of the U.S., became that much more likely because of such interventions that were largely driven by the Cubans, but partially aided, in some instances, by the Soviets.

\section{The Global Cold War in South Africa:}

The 1960s was a volatile decade for South Africa. To contextualize, Britain began to transfer power to African nationalists in Ghana, Sierra Leone, Nigeria, and Gambia in 1957. In 1960, France gave up control over their colonies in west and central

\footnotetext{
${ }^{63}$ Ibid, 191.

${ }^{64}$ Ibid, 211-212.
} 
Africa. Also, Belgium withdrew from Congo (Zaire). ${ }^{65}$ In South Africa, the decade opened with the Sharpeville Massacre on March 21, 1960 in which 69 people were killed in a peaceful protest against pass books. This stemmed from the harsh pass laws that were passed by Hendrik Verwoerd's National Party. He resumed the 1930s pro-racist reconstruction world view and intensified racist policy by moving the black majority onto Bantustans and regulate them using pass books, a major source of insult and contention for black South Africans. ${ }^{66}$

In addition to passing even more pass laws and Bantustan regulations, the whiteminority South African government banned the African Nationalist Congress (ANC) and Pan-African Congress (PAC). The Executive and Legislative branches reacted to this with some level of shock, agreeing to place apartheid permanently on the UN Security Council's agenda. Kennedy also set up a highly selective arms embargo one full year prior to the UN. ${ }^{67}$ By 1961, the ANC, PAC, and South African Communist Party (SACP) all began to use violence when attacking apartheid which diverted dramatically from the highly encouraged use of non-violent acts by these groups to fight pass laws. ${ }^{68}$ This uptick in violence of course resulted in even more laws passed by the South African government, including allowing for repetitive detentions of up to 90 days without trial (General Law Amendment of No. 76 of 1962). By 1967, laws were passed that allowed detention without trial for indefinite amounts of time. ${ }^{69}$

\footnotetext{
${ }^{65}$ Thompson, 214.

${ }^{66}$ Iris Berger, South African in World History (New York: Oxford University Press, 2009), 122-123, 127.

${ }^{67}$ Christopher Coker, The United States and South Africa, 1968-1985: Constructive Engagement and Its Critics (Durham: Duke University Press, 1986), 5-6.

${ }^{68}$ Annette Seegers, The Military in the Making of Modern South Africa (New York: Tauris Academic Studies, 1996), 122, 124.

${ }^{69}$ Ibid, 126-127.
} 
To keep the U.S. and western Europe off their proverbial backs, the South African government chalked up the violence used by the ANC, PAC, and SACP to the influence of the Soviets. The South African government took steps to portray itself as a stable, civilized, and indispensable member of the west and that tolerance needed to be afforded towards them for taking preventative steps to maintain control particularly among the population that was heavily influenced by such groups. ${ }^{70}$ How influential were the Soviets in South Africa?

Many historians feel that the reality of the threat was minimal at best. John Daniel argued that they had very little influence in the region, stating that even though the "Cold War paradigm was a myth," this did not mean that National Party leaders like Botha and Malan did not sincerely believe that they were fighting on behalf of western countries' interests. ${ }^{71}$ This is not to say that the South African government did not have a legitimate fear of the Soviets filling in a void that was left by the crumbling colonial system, especially with Portugal losing their African footing in 1974, thus completely eliminating the geographical buffer the South African government felt between themselves and African states not associated with a western colonial power of some sort. Leonard Thompson agrees with Damiel, arguing that even though the Soviets did dabble in Africa, giving them weapons through East Germany to the resistance movements in Angola, Mozambique, and Rhodesia, the Soviets were far less menacing then the

\footnotetext{
${ }^{70}$ Thompson, 215.

${ }^{71}$ Sue Onslow, ed., Cold War in Southern Africa: White Power, Black Liberation (New York: Routledge, 2009), 51.
} 
possibility of a black majority deciding to openly revolt against a very small white minority in South Africa. ${ }^{72}$

This is not to say that there was no connection between the Soviets and the ANC, PAC, and SACP. There was definitely a connection between the two, but it was not nearly as extensive as the South African government would have had the U.S. government believe. There were a few connections between sub-Saharan Africa and the early Soviet Union as far back as 1921 when the Communist Party of South Africa (CPSA) had representation in Cominterm, later replaced by Cominform after WWII. ${ }^{73}$ In the 1960s, with African nations beginning to claim independence and newly formed political contingencies voicing their desire to build their societies around socialist ideals, Khrushchev responded with enthusiasm. ${ }^{74}$ Khrushchev in general was far more interested than his predecessors in Africa. In the summer of 1960, Khrushchev attended the UN to welcome the sixteen newly admitted African states. He liked the idea of the anti-imperialist fire of the first generation of African leaders and wanted to capitalize on it. $^{75}$

Depending on the historian studied, there are a variety of views on the level of importance and aid the ANC and SACP received from the Soviets. Vladimir Shubin, author of The Hot "Cold War": The USSR in Southern Africa, argued that Moscow heavily influenced the ANC and ultimately were responsible for aiding their struggle and

\footnotetext{
${ }^{72}$ Thompson, 216.

${ }^{73}$ Apollon Davidson and Irina Filatova, "African History: A View From Behind the Kremlin Wall," in Africa in Russia, Russia in Africa: Three Centuries of Encounters, ed. Maxim Mtusevich (Trenton: Africa World Press, Inc., 2007), 112-116.

${ }^{74}$ Ibid, 117.

${ }^{75}$ Christopher Andrew and VasiliMitrokhin, The World Was Going Our Way: The KGB and the Battle for the Third World (New York: Basic Books, 2005), 426.
} 
keeping the groups afloat, particularly after the Sharpeville Massacre. He wrote that the ANC and SACP got a significant amount of guerilla training from Moscow and that the training was conducted in Minsk and Belarus. In addition, they requested weapons and received them via Dar es Salaam and Maputo drop points. ${ }^{76}$ Christopher Andrew and Vasili Mitrokhin, authors of The World Was Going Our Way: The KGB and the Battle For the Third World argued a different point. They said that South Africa was the only KGB success story in sub-Saharan Africa but only because of the connections the SACP kept open with the ANC and PAC. In addition, although Shubin leaned this way, Andrew and Mitrokhin argued that the ANC was "never really a full Communist puppet, but it was heavily sustained by the Soviet support and KGB back channels."77

What did aid from the USSR look like? In the 1960s, the USSR did begin to give assistance to the ANC and SACP. Much of the aid was awarded to the Umkhonto we Sizwe (Spear of the Nation), or the armed wing of the ANC and SACP. In 1963, the ANC got $\$ 300,000$ in aid from Moscow, while the SACP got an addition $\$ 56,000$. $^{78}$ One of the reasons for this discrepancy in dollar amount between the groups is because the SACP at this point operated out of London, whereas the ANC had just moved to neighboring countries around South Africa and launched raids from outside borders. As for the guerilla training that the ANC and SACP granted, it was reported that the Soviets had been sent to ANC camps in Tanzania and Zambia in 1964; however, there is little information to support this, according to Shubin. He argued that it was not until 1979

\footnotetext{
${ }^{76}$ Shubin, 242-243.

${ }^{77}$ Andrew and Mitrokhin, 430.

${ }^{78}$ Vladimir Shubin, "Beyond the Fairy Tales: The Reality of Soviet Involvement in the Liberation of Southern Africa," in Africa in Russia, Russia in Africa: Three Centuries of Encounters, ed. Maxim Matusevich (Trenton: Africa World Press, Inc., 2007), 340.
} 
that the Soviet instructors began to show up in ANC camps. ${ }^{79}$ However, from 1963 1991, over 1500 ANC activists did get trained in Soviet military institutions. ${ }^{80}$

\section{Operation Mayibuye:}

The early 1960s saw a shift in the ANC from violence to non-violence. Of particular concern to the ANC was the Sharpeville Massacre. After the massacre, there was a conscience decision among the leadership of the ANC to begin using underground subversive tactics to make violent in-roads on the fight against apartheid. Thus, the Umkhonto we Sizwe (commonly referred to as MK) was formed on December 16, 1961. Between 1961-1963, the MK undertook over 200 operations designed to damage public facilities. $^{81}$

The most ambitious plans laid out by the MK was Operation Mayibuye (see Appendix B for the full text of Operation Mayibuye). This was a six-page detailed plan that described how the MK might spark a mass armed uprising against the apartheid government. The plan was discovered during a raid of Arthur Goldreich's farm, known as Lilliesleaf. During the raid on July 11, 1963, South African authorities found a hundreds of ANC documents, along with 16 major ANC leaders such as Goldreich, Walter Sisulu, and Govan Mbeki. ${ }^{82}$ These arrests ultimately led to the infamous Rivonia

\footnotetext{
${ }^{79}$ Vladimir Shubin, "Unsung heroes: The Soviet military and the liberation of Southern Africa," in Cold War in Southern Africa: White Power, Black Liberation, ed. Sue Onlsow (New York: Routledge, 2009), 155.

${ }^{80}$ Ibid, 158.

81 “The Rivonia Trial and Lilliesleaf Farm," South Africa History Online, 3 May 2011, www. sahistory.org.za.

${ }^{82}$ Ibid.
} 
Trials where the ANC's top leaders were tried and placed in jail for several decades prior to the crumbling of apartheid in the 1990s.

Operation Mayibuye, while allegedly never adopted by the ANC and the MK, laid out detailed plans for how to spark a mass uprising. Nelson Mandela, who was arrested prior to the Lilliesleaf raid, said that the plan was "entirely unrealistic in its goals and plans." The plan specifically declared areas that would be targeted, such as Port Elizabeth, Port Sephstone, North Western Transvaal, and North Western Cape. It called for coordinated landings of four groups of 30 by ship and air to the designated areas. These groups would then work methodically to arm local populations that would become the core of future guerilla units. After arming the people, they would pre-select targets that, if they were attacked, would create mass chaos and confusion, thus hoping to incite more people to join the rebellion. ${ }^{83}$

In addition to the military plans of Operation Mayibuye, a massive propaganda campaign would be launched domestically and internationally to garner more support for the operation. Their means of communication would be via radio transmission to reach "the world and to the people of South Africa." The MK felt that once the rebellion was in full swing, they would need coordination of international support to deal the final blow to the fastidious apartheid regime. ${ }^{84}$

In looking at the document, there were clearly holes in their plan, or at least elements that were not addressed on paper. For example, there was no mention of where they would get weapons from. It could be inferred from Goldreich's history that they

\footnotetext{
83 “Operation Mayibuye," The Rivonia Trial, 3 May 2011, law2.umkc.edu/faculty/projects/ftrials/mandela/mandelahome.html. ${ }^{84}$ Ibid.
} 
may have received weapons from China, East Germany, and the Soviet Union, as he traveled to these places prior to the raid. But, it is unclear if he got weapons or a significant amount of aid from any of these countries. ${ }^{85}$ In addition, they never specifically named outside countries that would have provided aid to them in the larger forums, such as the United Nations. In fact, the only other country that was named specifically was Castro's Cuba, but only as an example of a successful uprising. ${ }^{86}$

Glenn Frankel, author of Rivonia's Children: Three Families and the Cost of Conscience in White South Africa, stated the obvious about how overwhelming and unrealistic the plan was. The plan called for 210,000 hand grenades, 48,000 antipersonnel mines, 144 tons of ammonium nitrate, 21.6 tons of aluminum powder, 15 tons of black powder, 1,500 bomb timing devices, 48,000 batteries, 260,000 detonators, and numerous types of machine tools with a knowledgeable workforce of 200 men to work with the machines and the materials. ${ }^{87}$ In addition to the sheer impossibility of the tactical side, there was a rift among the ANC and MK leadership about how realistic the plan was, with men like Goldreich and Joe Slovo arguing that it was possible, while Walter Sisulu and others liked the plan but felt it was impossible given the current political climate. ${ }^{88}$

Whether or not Operation Mayibuye was on the U.S.'s radar screen while they were making foreign policy and economic decisions concerning South Africa is unclear. It does not appear in any documents that were available to my research, such as the

\footnotetext{
${ }^{85}$ Douglas Martin, “Arthur Goldreich, a Leader of the Armed Fight to End Apartheid, Dies at 82," New York Times, 27 May 2011, www. nytimes.com.

86 "Operation Mayibuye."

${ }^{87}$ Glenn Frankel, Rivonia's Children: Three Families and the Cost of Conscience in White South Africa, (New York: Farrar, Straus, and Giroux, 1999), 107-108.

${ }^{88}$ Ibid, 109.
} 
Foreign Relations collection. However, they must have known about it because it was a topic for discussion at the Rivonia Trials and weighed heavily in determining how the ANC leaders captured in the Lilliesleaf raid should be punished. ${ }^{89}$ The operation must not have been enough of a threat to garner an immediate reaction from the U.S. in the form of recanting the arms embargo or retracting negative statements made about apartheid on the record.

Communism, South Africa, and the U.S.:

There was some level of concern in both the State Department and Joint Chiefs of Staff that communism was a legitimate threat. In 1964, National Security Action Memorandum No. 295 was drafted, in which the United States proposed to take a tougher stance on the National Party's racial policies by threatening to pull the satellite and missile tracking stations, suspending loans and monetary aid, and reviewing the selling of weapons and submarines to the South African government. The Joint Chiefs of Staff were largely unhappy with these recommendations by the State Department. Max Taylor of the Joint Chiefs of Staff expressed his concerns to Secretary of Defense Robert McNamara, saying:

For these reasons, the Joint Chiefs of Staff reiterate their views that the objectives of the United States toward South Africa should include its alignment with the Western Powers and the continuance of existing deep-space and tracking facilities in South Africa. As long as communist penetration and racial discord in Africa remain an active threat to Free World interests, stability in South Africa is desirable and the United States should do everything that its political and moral position permits to contribute to this. ${ }^{90}$

\footnotetext{
${ }^{89}$ Ibid, 244-245.

${ }^{90}$ Memorandum From the Joint Chiefs of Staff to Secretary of Defense McNamara, 22 May 1964, FRUS 1964-1968, XXIV [data base online].
} 
Clearly, not everyone was on board in believing that communism was not a threat and therefore that the relationship with the South African government was far more valuable than the fall out of associating with apartheid openly.

It should be noted that shortly after the Independence incident, South African industrialist Harry Oppenheimer, a liberal South African whose views starkly contrasted Verwoerd's racial policy, came to visit the United States in an effort to maintain U.S.South African relations, particularly when it came to private business. In a memorandum for the President's Special Assistant McGeorge Bundy and Ulric Haynes of the NSC to Johnson, Bundy and Haynes specifically stressed how concerned they were by the increasing mandates the South African government were taking in restricting racially integrated actions, such as inter-racial Embassy gatherings or inter-racial crews from the U.S. working at bases in South Africa. It was this type of attitude that was deemed more risky by Bundy and Haynes to pave an avenue for Soviet penetration than anything else:

We are in turn deeply concerned about the accelerating trend toward Governmentsanctioned racial discrimination ("apartheid") and extreme political repression in South Africa. "Apartheid" in particular is a major handicap to the Free World in its efforts to stabilize the political situation in Africa and keep the Chicoms and Soviets out... The gut problem in our relations with South Africa is that the policies of the Verwoerd government are driving the rest of the world into a kind of opposition which in turn will probably only make the South Africans more bitter and determined. ${ }^{91}$

The government could have been more concerned with the connections between the ANC, PAC, and SACP with the Soviets, but the alienation afforded by the National Party was far more of a threat in this department.

\footnotetext{
${ }^{91}$ Memorandum From the President's Special Assistant for National Security Affairs (Bundy) and Ulric Haynes of the National Security Council Staff to President Johnson, 10 June 1965, FRUS 1964-1968, XXIV [data base online].
} 
It would be presumptuous to assume the global Cold War cast a distinct shadow on U.S.-South African relations during the 1960s and early 1970s. However, while there were ties between groups like the ANC, PAC, and SACP with the Soviet Union, China, and East Germany, it was not enough of a threat for the U.S. to react as strongly as they did in such circumstances as Greece, Turkey, Cuba, and Guatemala. Thus, when looking at the decisions made by the Executive branch and military leaders of the U.S. during this era, historians must explore the issues that challenged U.S.- South African relations during the global Cold War, such as the NASA tracking stations, port usage, and arms embargoes, beyond traditional ideological parameters. U.S. foreign policy towards South Africa was more complex than keeping the Soviets at bay within that country and region.

The following three events illustrate the argument calling for greater differentiation made on the previous pages. They are ship docking procedure, satellite tracking stations, and the rivalry with Charles de Gaulle in the South African arms market. 


\section{Chapter Two: USS Franklin Delano Roosevelt}

A string of incidents that involved United States naval fleet docking at various ports in South Africa illustrates the cross-roads of civil rights, national policy making, and the global Cold War in South Africa. It is significant not because it illustrates another example of east battling west; rather, it suggests a vacancy of the concern of the Soviets by the U.S. More importantly, it establishes the significance of the availability to ports technologically advanced enough that the U.S. could use during the global Cold War to house and fix ships that were passing through.

The context of this time period is important to note, particularly before looking at the particulars of the USS Franklin D. Roosevelt incident. The 1960s ushered in major conflict on the domestic U.S. scene, namely that of the black civil rights movement and the Vietnam War. Executive and Legislative branch decisions became increasingly scrutinized by the U.S. public throughout the 1960s with relation to the civil rights movement and the Vietnam War. Relations with the South African government were unique in that respect because it tied together two major issues that dominated the media, particularly in the late- 1960s.

Political decisions about apartheid South Africa were being made in a country that was in the throes of racist Jim Crow laws. Washington D.C. itself had a strong Jim Crow tradition. In fact, African officials of newly independent African countries were very concerned to be posted as ambassadors in the U.S. and much preferred to be located in 
Europe. Washington was surrounded by segregationist states, such as Delaware, Maryland, and Virginia. ${ }^{92}$

President John F. Kennedy was motivated to encourage the passing of a Civil Rights bill for a multitude of reasons. One of the major benefits of passing such a law was that he knew he would improve relations with African delegates if he could show his commitment to decreasing segregation within the U.S. ${ }^{93}$ Thomas Borstelmann argued the significance of improving race relations within U.S. borders:

In the southern parts of North America and Africa, racial polarization threatened to destroy the multiracial unity that the Kennedy administration believed crucial for its own political success at home and for American victory in the anti-Soviet struggle abroad. ${ }^{94}$

The reality was that the Kennedy administration became more sympathetic towards with apartheid rule in South Africa, despite the arms embargo that will be discussed in chapter four, while getting tougher on segregationist governors in states like Alabama and Mississippi. $^{95}$

It would not be until President Lyndon B. Johnson was in power that the Civil Rights Acts of 1964 and the Voting Rights Act 1965 were passed, leading the way to more integration and rights for the black community in the United States. Between 19641968, the height of the death rattle of Jim Crow laws directly collided with the Vietnam War, where military recruits were proportionally higher among black than whites. Civil rights leaders like Martin Luther King, Jr. saw major contradictions in demanding the

\footnotetext{
92 Thomas Borstelmann, The Cold War and the Color Line (Cambridge: Harvard University Press, 2001), 165.

${ }^{93}$ Ibid, 167.

${ }^{94}$ Ibid, 169.

${ }^{95}$ Ibid, 170-171.
} 
U.S. government for black Americans to fight for the preservation of U.S. freedoms at home, despite not being allowed those freedoms themselves. While there was major rioting in response to the Civil Rights Acts in 175 U.S. cities in 1967, black American soldiers were immersed in guerilla warfare thousands of miles away in Vietnam. In the words of one anonymous solider, "'How is it possible that all these people could be so ungrateful to me after I had given them so much?",96

When the USS Franklin Delano Roosevelt went to dock in South Africa, a trifecta of issues that had largely been buried by the media's coverage of the Vietnam War consolidated. U.S. policy towards South Africa became front-page news in February 1967 because of a ship carrying black soldiers during a politically contested war. Unwanted exposure about U.S. relations with South Africa was revealed for all to see.

\section{The Incident:}

On February 2, 1967, the New York Times began to carry headlines featuring the possibility of the USS Franklin Delano Roosevelt docking in South Africa. On board, there were an estimated 100-300 black servicemen among the 3,500 total enlisted men. They were returning from Vietnam and expected to get leave in South Africa upon docking. As reported, civil rights leaders were immediately concerned about the implication of leave for the black soldiers. The NAACP sent a telegram to Washington urging them to reconsider docking the ship in Cape Town. The ship was due into the port February 4, 1967. ${ }^{97}$ However, this issue did not begin on February 2, 1967; rather, it

\footnotetext{
${ }^{96}$ Ibid, 173.

${ }^{97}$ Thomas A. Johnson, “Call At Capetown By Ship Opposed,” New York Times, 2 February 1967, pg. 12.
} 
started with the issue of the docking of the USS Independence in 1965 when there was a brief diplomatic skirmish between the U.S. and the South African government about leave rights for black servicemen who were docking in South Africa.

In May 1965, the USS Independence asked permission for planes from the carrier to land at South African airports, a rather routine request. In an unusual twist, the South African government, led by Hendrik F. Verwoerd, agreed, but there were stipulations: the planes' crews had to be white. In the past, black crewmen had been seen landing and docking both at airports and naval ports. The U.S. inquired further- was this a suggestion or a condition? The Verwoerd government did not clarify. In June 1965, Verwoerd took this request a step further and demanded that no black U.S. workers were to be permitted to work on NASA satellite tracking stations in South Africa (this issue will be addressed in chapter three). ${ }^{98}$ Verwoerd clearly took a tough line against the U.S. nonsegregationist policy by banning (officially or unofficially) mixed race crews from using ports or working within the borders of South Africa. In addition, Verwoerd scolded U.S. embassies for holding multi-racial functions within South Africa, something that would obviously be unacceptable in an apartheid state. In a memorandum from the NSC to Johnson, they said:

Your accomplishments in race relations and civil rights here at home make it essential that our position on similar issues abroad be consistent with domestic policy. Failure to do so if this issue becomes widely publicized would alienate members of Congress, American Negroes, civil rights groups, labor, church groups, and liberals in general. ${ }^{99}$

\footnotetext{
98 Joseph Lelyveld, "Verwoerd Race Bar Challenges U.S. at Space Tracking Stations," New York Times, 28 June 1965, pgs. 1, 8.

${ }^{99}$ Memorandum from Charles E. Johnson and Ulric Haynes of the National Security Staff to President Johnson, 13 July 1965, FRUS 1964-1968, XXIV: 1030-1031.
} 
The NSC essentially warned Johnson of the dangers of making decisions that, while internationally may have made sense, would have been destructive to his image domestically.

The Independence incident set a precedent of caution by the U.S. Executive branch in the use of South African ports because Johnson feared a backlash from the U.S. public by being viewed as condoning the policies of apartheid, while a race war was raging inside U.S.'s borders. Essentially, it became frowned upon for the U.S. military to use South African ports, but that is not to say that ports were not being used between 1965 and 1967. There were at least four visits made by major U.S. ships, including the Valdez in Cape Town from December 13, 1966- January 2, 1967, the Coastal Crusader in Durban from October 25- November 29, 1967, the Sword Knot at various dates in 1966-1967 in Cape Town, and the Twin Falls during various dates in 1966-1967 at Cape Town and Port Elizabeth. Granted, most of these ships were contracted out and/or had few military personnel on board, but they still used the ports, despite the Independence "policy."100

The Independence policy set a precedent for the U.S. Executive branch and military to follow when determining whether or not it was appropriate for the aircraft carrier USS Franklin Delano Roosevelt to dock in Cape Town, and if it were to dock, if they would allow leave for their soldiers, despite having black servicemen on board. The State Department knew that the landing of the Roosevelt at Cape Town would be an issue. In June 1967, there was a choice to permit the Roosevelt to dock in Cape Town or

\footnotetext{
${ }^{100}$ National Archives, General Records of the Department of State, RG 59, "U.S. Naval Calls at South African Ports,"Def 7 SAFR-US, 24 February 1967.
} 
to fuel it from an oiler in the sea and have shore leave at Rio de Janeiro. A third option was to refuel in Malagasy, but this would cost an additional \$100,000- 200,000. Johnson preferred to go via Rio, but Secretary of the Navy Paul H. Nitze said that Cape Town was the preferable route. ${ }^{101}$ They went with Nitze's recommendations.

It is not clear when the civil rights community discovered or were told that the Roosevelt would dock in Cape Town, but the reaction was simple, strong, and united. On January 30, 1967, Roy Wilkins, A. Philip Randolph, and Theodore E. Brown, leaders in the civil rights community, wrote to Secretary of State Dean Rusk and stated, in addition to the violation of the precedent set by the Independence incident and past policies towards apartheid, "Such a visit will [be] an insult to American Negroes, to the black people of Africa and to democratic [men] through the world dedicated to the elimination of apartheid." ${ }^{\prime 102}$ The initial response by the Secretary's office was that of acceptance of the Roosevelt docking at Cape Town. They claimed that the Independence incident was isolated and that since then, the U.S. had used South African ports routinely and even allowed leave for mixed racial crews. In addition, to deny the crew of the Roosevelt leave would be inhumane: "We deplore apartheid policy but cannot ignore the importance of shore leave for humanitarian and morale purposes."103 The Secretary of State surprisingly admitted the use of ports since the Independence incident and went on to support the need for leave for the ship's crew. This view would change very quickly over the next few days prior to February 4, 1967, when the ship was scheduled to dock.

\footnotetext{
${ }^{101}$ Memorandum from the President's Special Assistant (Rostow) to President Johnson, 22 June 1966, FRUS 1964-1968, XXIV: 1050-1052.

${ }^{102}$ National Archives, General Records of the Department of State, RG 59, “The Secretary of State,"Def 7 SAFR-US, 30 January 1967.

${ }^{103}$ National Archives, General Records of the Department of State, RG 59, "Letter to Roy Wilkins," Def 7 SAFR-US.
} 
When the news broke in the newspapers on February 2, 1967, naval authorities stuck to their rationale of allowing shore leave for morale and operational reasons. The men aboard the ship were coming home from Vietnam after having 95 days without any sort of a break. Cape Town was exactly halfway from Subic Bay in the Philippines to Mayport, near Jackson, Florida. Thus, the port served as a great place for leave and an important spot for refueling prior to embarking on the last 7,000 miles. The ports were equipped with the capability to fix ships should they need any repairs. They also denied that allowing the leave and port visit was violating some sort of Navy policy that required, or strongly urged, ships to avoid South African ports. ${ }^{104}$

Despite this rationale, many members of Congress protested the decision. The New York Times reported that 40 members of Congress complained to Johnson that, "a visit would condone South Africa's policy of apartheid." They also pointed out that the Independence incident did not merely produce a loose policy to abide by when possible, but that in 1965, G. Mennen Williams, the Assistant Secretary of State for African Affairs, made it clear that all future naval stops at South African ports should be canceled. More moderate Congressmen suggested that the State Department should still allow leave, but make it clear that the U.S. still heavily condoned the use of apartheid. The result of such Congressional discussions was that Deputy Defense Secretary Cyrus

\footnotetext{
${ }^{104}$ Benjamin Welles, "Navy Stands Firm on Capetown Visit: Javits and Percy Are Among Congressional Critics," New York Times, 3 February 1967, pg. 10.
} 
R. Vance and Secretary of the Navy Nitze announced that sailors would be granted "“modified shore leave in connection with integrated activity only.",105

The U.S. State and Defense Departments were not only being pressured by civil rights leaders and moderate and liberal Congressmen, but they were receiving a fair amount of criticism from South African press. The incident was portrayed in a variety of ways in the press prior to the ship landing at the port. The most alarming to the State Department was the message in pro-Nationalist paper Die Burger, which stated in columns and editorials that this was an attempt by the U.S. to isolate South Africa from the international community, and that the South African government must not succumb to pressure to respond to the taunting by the American Naval and State Departments. ${ }^{106}$ The ports in South Africa were clearly important to the U.S. Navy; thus, bad press by the South Africans would not help enable open access to them.

By February 4, the State Department issued a declaration suspending the leave of any soldiers from the Roosevelt. The Ambassador of South Africa, William M. Rountree, reported to the Secretary of State's office in Washington that:

As result painstaking review alternatives with Captain [William G.] O'Neill and Executive Officer FDR and senior members my staff, we have reached reluctant conclusion that only adjustment in fairness to all concerned which can be made to comply with instructions REFTEL is cancel all liberty....

\footnotetext{
105“Shore Leave Curb Set at Capetown: U.S. Sailors Are Restricted to Integrated Activities," 3 February 1967, pg. 11. Also, National Archives, General Records of the State Department, RG 59, "FDR Call," Def 7 SAFR-US, 3 February 1967.

${ }^{106}$ National Archives, General Records of the State Department, RG 59, "REF: Capetown's 707," Def 7 SAFR-US, 3 February 1967.
} 
It is unclear if this decision was made by Rountree and the captain of the Roosevelt or by the State Department. Furthermore, Rountree reported on press release alerting the international community of the decision:

The American Ambassador, Mr. William M. Rountree and Captain William G. O'Neill, Commanding Officer of the U.S.S. Franklin Delano Roosevelt, wish to thank the South African authorities and public for their great generosity in offering hospitality to the personnel of the carrier visiting Cape Town. Because of difficulties in organizing leave arrangements, it will not be possible for these kind offers to be accepted. The carrier will remain in Cape Town for refueling and provisioning as scheduled. The public is cordially invited to visit the ship during the scheduled hours.

Ultimately, it was decided that integrated visits aboard the ship would be allowed, in addition to trying to salvage as many of the off-shore activities so long as they could be accommodated on board. Rountree stated that the Captain was very persuasive in arguing against shore leave when he said that the impact of off-shore leave and being exposed to apartheid on the $10 \%$ non-white soldiers would not be worth the negative press that would most likely come with canceling activities planned by South African hosts. ${ }^{107}$ The press release was a polite decline designed to keep the U.S. Executive branch in favor with the South African government and to lessen the blow that could be delivered by the South African government. But, it also took as step towards merting the needs of civil rights leaders and the vocal Congressmen upset by the docking of the Roosevelt in Cape Town.

The details of the leave were not released to the public, though if it had been, it would have cut down on some of the criticism that was delivered by domestic and international press. The Navy did not solicit offers for shore leave activities, rather they

\footnotetext{
${ }^{107}$ National Archives, General Records of the Department of State, RG 59, “Cape Town 737,"Def 7 SAFRUS, 4 February 1967.
} 
were deluged with numerous offers from the South African government and private individuals and groups. The program for leave was planned on the eve of the visit and consisted of mostly integrated activities, such as church services, shopping, cable car rides, and bus tours. However, there were a few segregated events, including offers of home stays and private dances. On February 3, Captain O’Neill received the Naval order that ALL activities must be integrated. Given that they were to dock in only a matter of hours, the Captain at that point decided that no leave should be granted because it would be impossible to sort through all of the activities and keep only the integrated ones available to soldiers. Also, logistical concerns, such as the use of segregated bathrooms during bus tours and shipping, would have broken the official orders given by the Navy. Thus, according to the State Department, the Captain made the best call he could, given his extremely limited time constraints. ${ }^{108}$

Prime Minister John Vorster, who replaced Verwoerd after he was assassinated in 1966 by a mentally ill person with no political motivations, did not wait long to make a reply to the seemingly diplomatic move by the U.S. Navy and State Department. ${ }^{109} \mathrm{He}$ thanked South Africans that offered their homes and hospitality to the soldiers for their good will. He apologized to them for putting in the time, money, and planning to provide a welcoming stay in their communities and homes. In addition, he clarified that at no time did the South African government ever put stipulations on the leave of the interracial crew. Furthermore, Vorster expressed his surprise at the sudden decision of the

\footnotetext{
${ }^{108}$ National Archives, General Records of the Department of State, RG 59, "Background Summary- FDR," Def 7 SAFR-US, 7 February 1967.

${ }^{109}$ Robert Kinloch Massie, Loosing the Bonds: The United States and South Africa in Apartheid Years (New York: Double Day, 1997), 208.
} 
U.S. Navy to cancel the leave after plans and discussions had been made and agreed upon by both South African and U.S. parties. ${ }^{110}$ Vorster may have been more upset about being notified of the cancelation of the leave through a general press statement, rather than personally, than by the actual cancelation of the leave.

The cancelation of leave and Vorster's response made for sensational press in South Africa on February 5, 1967, with South African papers claiming that upset citizens went on board demanding answers from the ship's crew and captain and that the ship's crew was visibly grumpy at not having leave. The Nationalist Die Beeld reported that all of South Africa had hoped this visit would usher in a new era of more amicable relations between the two countries. Despite these headlines, the embassy in Cape Town reported, "Despite sharply critical nature of much of official and press reaction, public interest and goodwill remain high as evidence of tremendous turnout for public visiting today."111

U.S. papers, including the New York Times and Washington Post, also looked at this event critically. ${ }^{112}$ On February 5, the New York Times published a "carefully worded" editorial, as the U.S. embassy in Cape Town would say, that looked at the impact of the docking of the ship domestically and internationally. The first paragraph stated:

With the carrier Franklin D. Roosevelt in Capetown, many South Africans, black and white, will conclude that they need not take seriously the official United States opposition to their Government's racial policies and its defiance of the United Nations on South West Africa.

\footnotetext{
${ }^{110}$ National Archives, General Records of the Department of State, RG 59, "Prime Minister's Statement on FDR,’'Def 7 SAFR-US, 4 February 1967.

${ }^{111}$ National Archives, General Records of the Department of State, RG 59, "FDR Call,"Def 7 SAFR-US, 5 February 1967.

${ }^{112}$ National Archives, General Records of the Department of State, RG 59, "FDR Call,"Def 7 SAFR-US, 6 February 1967.
} 
In addition, it claimed that the Department of Defense had "managed once again to interfere in the conduct of American diplomacy and create the impression that one branch of government is ignorant of or indifferent to the policies of another." The editorial lobbed the idea that the Navy should have known better than to even risk exposing the 3,800 person crew to the ugliness of apartheid, despite promises of fully integrated activities, especially with Nitze at the helm of the Navy, considering that he was once chief of the State Department policy planning and should have been able to recognize potential policy pitfalls. $^{113}$

The London Times was very critical of the events surrounding the cancelation of leave, more so than the New York Times, pointing out anomalies that U.S. papers missed in assessing the situation. Why did the carrier need to go past the Cape? The article suggested that sailing past the Cape of Good Hope was hardly routine upon returning from Vietnam to North America. Also, why did the Navy potentially plan to subject a large amount of servicemen to the realities of apartheid by attempting to plan integrated and equal activities for all crew in Cape Town? The article then turned to the significance of the event, specifically pointing out that the U.S. diplomatic attitude towards South Africa was unsteady and unpredictable at best. In relation to England's policy towards South African, the article suggested strongly that the decision to use South African ports undermined their own attempt to oppose the Nationalist regime and its use of apartheid through diplomatic means. ${ }^{114}$ This newspaper article raised questions that major papers in the U.S. failed to consider, such as why the route past the Cape was

\footnotetext{
113،"Was This Call Necessary?” New York Times, 5 February 1967, pg. E8.

114،“Fumbling at Cape Town,” The Times, 6 February 1967, pg. 11.
} 
selected. However, this article's coverage is subject to similar shortfalls as the New York Times because they failed to mention key glitches in their criticisms, such as the fact that England was selling the government of South Africa serious weapons.

To further this negative depiction of the incident, The Times reported that the picture on board the ship was not as civil and pleasant as Rountree would like to have reported. "While nearly 4,000 angry members of the crew are confined to their ship in one the world's most hospitable ports... a bitter quarrel has broken out between the South Africans and American governments over what it had been hoped would be a good-will visit." ${ }^{115}$ In addition, The Times reported that signs posted by the servicemen indicated that they heavily regretted not being able to disembark and spend time in the South African communities which suggested "that they disagreed with Washington orders that made leave impossible." $" 116$

This was somewhat of a different picture than what the New York Times reported. The New York Times did highlight the disgruntled nature of soldiers, even pointing out that black servicemen wanted to see what apartheid was like for themselves; however, short of the editorial on February 5, they hardly delved into the larger implications of this event on South African-U.S. relations. They depicted a mutual disgruntlement of soldiers and visitors alike that was not directed specifically at either of the two governments, but rather at "politics in general." However, they did ponder what this meant on South African-U.S. relations, especially given headlines from South African newspapers such as Die Beeld, which stated, "South Africa's hand of friendship, which was given to the

\footnotetext{
115،"U.S. Carrier Expected to Leave S. Africa Today: Bitter Quarrel over Colour Bar,” The Times, 6 February 1967, pgs 1, 11.

116“'S. African M.P.s Boycott U.S. Carrier,” The Times, 7 February 1967, pg. 8.
} 
United States this weekend... has been suddenly and rudely knocked aside." ${ }^{117}$ Given that embassy records show significant concerns about media coverage of the event, the U.S. government was concerned about the image being created of them by this incident.

On February 9, 1967, a particularly lengthy Department of State airgram from the Cape Town Embassy to the State Department was sent depicting a news story from February 6. Whereas other airgrams and telegrams being exchanged between the two State Department groups were short summaries of news stories from around the world, this one focused at length on a South African Broadcasting Company (SABC) story that criticized U.S. policy choices. On SABC's "Current Affairs," it was alleged that because the visit was originally orchestrated by the Department of Defense and canceled so abruptly by the State Department, one could have concluded that "liberals" like UN Ambassador Arthur Goldberg and Senator Robert Kennedy (D-NY) were behind the change of plans. More significantly, the SABC imposed the idea that apartheid was a "mutually accepted fact" and that people like Goldberg, who visited South Africa in 1966 and appealed to U.S. businesses to uproot themselves from South Africa in a show of solidarity against apartheid, were turning the U.S. government into hypocrites who could not be trusted or relied upon. The reversed decision of allowing leave was a sign of the times- U.S. policy was surely changing towards South Africa, said the SABC.

Furthermore, the "Current Affairs" piece depicted the Department of Defense and private U.S. business as the good guys, whereas the State Department was clearly painted as the

117“"U.S. Carrier Cuts Visit to Capetown,” New York Times, 6 February 1967, pg. 10. 
"villain" in this situation. ${ }^{118}$ This negative press may have been cause for concern among the State Department that there was clearly a depiction of them as being disjointed from the other departments in government and that their move was unilateral, despite evidence to the contrary.

Ultimately, on February 7, 1967, the Roosevelt left for Florida, leaving in its wake more questions than answers about its impact on foreign policy, the potential fall-out between South African- U.S. relations, particularly among the Executive branch and military co-operation, and the future use of South African ports, airports, and satellite tracking stations by the United States. Essentially what could have been a minor bump for U.S. diplomacy among the Executive branch and the Joint Chiefs of Staff turned into a jumble of national civil rights issues crossed with global Cold War concerns and mixed with economic questions.

\section{Implications of the Roosevelt Visit:}

After the Roosevelt docking, months were spent in the State Department, Congress, and the Department of Defense discussing what to do. Before looking at their reactions, it is important to contextually frame this incident internationally and look at the strategic significance of the ports. A natural place to look then would be at why the United States military wanted to use these ports, which leads the issue back to the Middle East and the Suez Canal Crisis.

\footnotetext{
${ }^{118}$ National Archives, General Records of the Department of State, RG 59, "SABC Lambasts US State Department for FDR Incident,'Def 7 SAFR-US, 9 February 1967.
} 
Nasser's nationalization of the Suez Canal on July 26, 1956, was much to the dismay of the West. ${ }^{119}$ The U.S. Executive branch and Joint Chiefs of Staff were surprised and concerned, particularly of the fate of U.S. ships- for both private enterprise and public military ships alike. The canal was a key avenue for U.S. ships going East, particularly ships related to the military. Thus, Suez was critical for ships going east for the Vietnam War, for access to India and the Indian Ocean, and, more obviously, to the Middle East. Should the Suez have had another crisis, like the one in 1956, the United States needed an alternative route. The best alternative, or what was being argued as the best alternative in 1967, was around the Cape of South Africa. As early as January 4, 1967, when discussing whether or not to allow the Roosevelt to go through Cape Town, the State Department took the following stance: "Department would like to use occasion of operationally desirably refueling visit of FDR to Capetown Feb 1-4 to establish principle that related flights from carrier would be permitted without racial conditions..." More specifically, they knew Cape Town was an advantageous spot to refuel and they wanted to maintain the precedent that the U.S. Navy could use the ports to refuel if need be despite racial considerations. ${ }^{120}$

The Legislative branch took up this debate as well. On July 12, 1967, Joe D. Waggonner, Jr. (D- LA), a critic of the denial of leave for U.S. soldiers and apparent supporter of the Nationalist government in South Africa, said:

South Africa has proved herself to be a valuable ally in the wake of the Middle East war by her cooperation in allowing American and British shipping to visit her ports while the Suez Canal remains closed.

\footnotetext{
${ }^{119}$ Charles D. Smith, Palestine and the Arab-Israeli Conflict, $5^{\text {th }}$ ed. (Boston: Bedford/ St.Martins, 2004). ${ }^{120}$ Telegram from the Department of State to the Embassy in South Africa, 4 January 1967, FRUS 19641968, XXIV: 1065-1067.
} 
He argued that the Cape Town route was vital to American shipping because 1500 ships used the Suez route and should that route's access to U.S. ships be tampered with again, a viable alternative needed to be in place. In addition, he claimed that South Africa had the only major dry dock in all of Africa able to accommodate cruisers and aircraft carriers, which were critical to immediate ship repair and maintenance during wartime. He was dismayed by the "liberals" and UN for criticizing such an important ally. He goes on to say:

One is reminded of the incredibly foolish and offensive decision by the White House not to allow crewmen of the aircraft carrier Franklin D. Roosevelt, returning from the Vietnam War, to enjoy liberty in Cape Town. Clearly, it is time that the Johnson administration make a public statement, repudiating the antiSouth African policy which endangers the vital interests of the United States and other friendly maritime nationals. Control of the Cape must remain in the hands of a stable, European-type government which will stand by the West in a time of crisis. $^{121}$

Waggoner was clearly frustrated because he saw a need to maintain access to the ports, apartheid or not. The reality was that the U.S. was at war with Vietnam and had other adversaries located on the east side of Africa in the Middle East, Asia, and the USSR. Should they need a central location to repair war torn ships, and especially if the Suez becomes inaccessible to the U.S. again, South Africa was a logical option for transit and ships repairs.

The importance of the strategic location of South Africa for the U.S. military, especially in lieu of the use of Suez, was of high importance to the Navy. Secretary of the Navy Nitze said that South African ports were extremely useful but not indispensable in relation to NASA and NSA mission requirements at the satellite and missile tracking

${ }^{121}$ Congressional Record, $90^{\text {th }}$ Cong., $1^{\text {st }}$ sess., 1967, 113, pt. 14: 18601-18602. 
stations. But, the use of those ports allowed for an efficiency that could not be substituted if they were to use Kenya's ports again. South Africa had the best ship repair facilities in sub-Saharan Africa; better than that of Kenya. Also, in relation to refueling stops, particularly in the route between the Pacific and Indian Oceans, the ports in South Africa were very beneficial for the U.S. to use, but not irreplaceable with at-sea refueling or the use of other ports in the area. However, the strategic importance of the South African ports during wartime was irreplaceable. They had five major ports, ten major airfields, technical competence in their ports and airfields, and allowed for control of access to vital sea lanes should they need them to the Indian Ocean and Far East, especially in the event that the Suez Canal was closed to U.S. access. ${ }^{122}$ Even though there were alternatives, there were many reasons to want to uphold access to these ports and airfields, despite pressure at home. This sentiment would be echoed in further memos from the Joint Chiefs of Staff to McNamara in that they too wanted access to these ports and airfields, despite the heavy objections from the home front in the U.S. ${ }^{123}$

Political idealism surfaced during the Congressional debates following the docking of the Roosevelt. There were more Congressmen concerned by the use of South African ports than those who thought it was perfectly fine to maintain access to the ports. Representative Don Edwards (D-CA) called the Roosevelt situation an "unfortunate episode." He said:

\footnotetext{
${ }^{122}$ Memorandum From the Secretary of the Navy (Nitze) to the Under Secretary of Defense (Vance), 4 March 1967, FRUS 1964-1968, XXIV [data base online].

${ }^{123}$ Memorandum From the Joint Chiefs of Staff to Secretary of Defense McNamara, 5 April 1967, FRUS 1964-1968, XXIV [data base online].
} 
We simply cannot do business with apartheid. The administration apparently appreciated this when it refused to dock the U.S.S. Independence in 1965, rather than accept the application of South Africa's racial policies.

He did not want the U.S. Navy to make any more calls to South Africa and that the State Department "should not seek to make private accommodations with the South African Government in direct opposition to precedent and previous policy." Use of the ports and showing support for apartheid went hand-in-hand for Edwards. ${ }^{124}$

Representative Donald M. Fraser (D-MN) agreed with Edwards and furthered the statement saying that the U.S. needed to have a strong, consistent, and clear policy that showed its commitment to racial justice in South Africa:

The incident dramatizes all the weaknesses of American policy in Africa. Consultation between the Departments of State and Defense seems to have been negligible. Precedent was ignored. African sentiment was disdained. And logistical needs were permitted to outweigh the clear demands for diplomacy. ${ }^{125}$

The Congressional Record reflects a divide among those who were okay with the status quo of not challenging apartheid so that they could maintain access to ports and those who felt this showed too much support for apartheid, but it is unclear just how many Congressmen would have settled on either side of the debate. Regardless, those who opposed the use of the ports must have asserted themselves strongly enough to the State Department because a need for a clear policy towards South African port usage became a topic of conversation after the Roosevelt visit.

Aside from the newspapers previously mentioned, several South African newspapers looked to the future implications of this visit and offered insight into the incident that deviated from Nationalist newspapers. The Eastern Province Hearld, a Port

\footnotetext{
${ }^{124}$ Congressional Record, $90^{\text {th }}$ Cong., $1^{\text {st }}$ Sess., 1967, 113, pt. 2: 2560-2561.

${ }^{125}$ Ibid., 2560.
} 
Elizabeth newspaper, spent a significant amount of time in the days following the Roosevelt visit looking at what this meant for them. Whereas some of their fellow countrymen's newspapers attacked U.S. hypocrisy, the Eastern Province Herald took a fairly moderate stance. In relation to the Independence incident, the newspaper stated on February 6:

South Africans are fully aware that in the eyes of the world American policy in this respect is considered to be right and their policy wrong. But within the ambit of their laws they had opened their hearts to the American sailors and airmen now marooned in the Duncan Docks and they are rightly resentful of the fact that their proferred hospitality is spurned. They had hoped to eradicate once and for all the memory of the ill-fated Independence incident....

Furthermore, on February 8, the Eastern Province Herald somewhat criticized their government for speaking out against the change of heart by the U.S., saying that they could have proved their "bigness in heart" had they turned the other cheek. Had the South African government gone aboard the ship in an act of goodwill, they would have helped improve the relations between the two countries, rather than strain it further.

The Evening Post of Port Elizabeth furthered this sentiment. While they did tend to blame the U.S. for this incident, they seemed to understand the U.S. State Department's rationale for not allowing leave in saying, “... the U.S. government is not prepared to allow men who are willing to die for the freedom guaranteed by their Constitution to be exposed to the indignities and restriction of apartheid; it would make a mockery of the struggle for freedom." They also pointed out that this incident should have taught South Africans that if they were to continue supporting apartheid, there would undoubtedly be international consequences, namely that of increased isolation from the "strongest military power in the West, the United States." An additional note is 
what the Daily Dispatch of Port Elizabeth said, which is that despite earning the reputation for being the most hospitable people "in the world," they had ultimately become "an embarrassment to her friends."126 These are perspectives that did not necessarily forgive the U.S. State Department for their decision, but it looked at the issue from that of growth rather than condemnation in relations between the two governments.

It is unclear if the State Department was responding to pressure from the media, Congress, or civil rights leaders, but they did begin to take a much harder look at what their policy should be for use of South African ports and installations. In a confidential memorandum sent on February 9, 1967 from Undersecretary of State Nicholas Katzenbach to Joseph Palmer II, the Assistant Secretary of State for African Affairs, Katzenbach stated that the Roosevelt incident called for a review of U.S. policy in regard to South African ports by the U.S. Navy. The old policy, or that which came from the Independence precedent, was to permit U.S. Naval vessels into South African ports if there was a need for provisioning and servicing, so long as there were not racial restrictions put upon crew. Would this type of policy still hold or should a more hardline policy be put in place? And if a more hard-line policy is put into place, how would that impact ships with mostly civilian crews or ships servicing the tracking stations located in South Africa? How would this impact American planes? More importantly, would all use of South African ports, airfields, and tracking stations need to be suspended because of a potentially more hard-line precedent set by the Roosevelt incident?

\footnotetext{
${ }^{126}$ National Archives, General Records of the Department of State, RG 59, "FDR Visit: Further Eastern Province Press Reaction,"Def 7 SAFR-US, 17 February 1967. Actual newspaper clippings from mentioned newspaper are included in this State Department Airgram.
} 
Katzenbach suggested that large warships should bypass South Africa all together, as it was unfair to expose large numbers of servicemen to apartheid. Also, this would help "demonstrate our abhorrence to apartheid." Small ships, on the other hand, would still be permitted to use ports, especially since these tended to carry scientific equipment that was needed in the tracking stations. In addition, ships with pre-approved clearance at the time of the memo, ships with repair contracts already made, and ships with majority civilian crews would be allowed, in addition to ships of all sizes if it were an emergency situation. Katzenbach speculated that the continued use of the ports would help ease tensions between the South African government and the U.S. government in the post- Roosevelt era. $^{127}$

The State Department and Navy needed to make a decision because the Sword Knot, a Navy Military Sea Transportation Service (MSTS) Trading Vessel, was scheduled to make a stop at Durban on February 12, 1967 for two months' worth of work. As mentioned previously, the Sword Knot had visited South African ports prior to the Roosevelt incident. However, on February 13, carrying electronic equipment, the Sword Knot had been left for four days with no word as to whether or not they could dock in Durban. On board were 67 crewmen, eleven of whom were black. ${ }^{128}$ The Sword Knot was being watched by the international community to see what the U.S. would do and how the South African government would react.

Behind the scenes, there were talks between the South African government and the U.S. State Department. South Africa was interested in keeping the U.S.'s shipping

\footnotetext{
${ }^{127}$ National Archives, General Records of the Department of State, RG 59, "Future Use of South African Ports,'Def 7 SAFR-US, 9 February 1967.

128“Navy Ship Awaits U.S. Assent for Visit to Durban,” New York Times, 14 February 1967, pg. 5.
} 
industry. There were discussions being held between the two parties on the lessening of racial law enforcement on visiting black U.S. soldiers. By direction of Prime Minister Vorster, local authorities and citizens were instructed to allow the crew to use any restaurant or bar as they pleased. Also, there would be no arrests or trouble whatsoever under "immorality or race laws." In fact, it was thought in some circles in South Africa that the Roosevelt incident may have started to pave the way towards lessening restrictions on non-whites in South Africa:

But I believe the Department will find interesting the fact that not only DFA officials but key moderate leaders like Anton Rupert, have advised that the Prime Minister had counted on certain liberalizing impact of FDR call to help him move gradually in direction improving lot of coloureds and reducing extremes of apartheid. They claim that FDR affair deeply regretted set-back to plans of PM and factor strengthening position of Afrikaner die-hards. Rupert said to [embassy officer] that he had been "waiting for twenty-five years for kind of forward movement now emerging under Vorster and which will continue despite set-back of [FDR] incident.'

Based on this assessment, the State Department highly recommended that the Sword Knot be permitted to use the Durban port. ${ }^{129}$

On February 13, Palmer made a recommendation to Katzenabach for the Sword

Knot. At this point, the South African government had already given the ship clearance "provided the crew is not restricted to the ship," a lesson learned from the Roosevelt docking. Palmer recommended three courses of action to be considered. The first was to permit the Sword Knot to enter Durban and for the crew to be given liberty with the caveat that they avoid any organized segregated activities. The second was to send the Sword Knot to a different port altogether. The third possibility, though Palmer did not

\footnotetext{
${ }^{129}$ National Archives, General Records of the Department of State, RG 59, "State 135679 and Cape Town 785,” Def 7 SAFR-US, 13 February 1967.
} 
recommend it, was to allow the work to be done on the Durban, but to not allow the crew any sort of leave. Palmer did not like this third option because it was expected that the ship would be there for two months.

There were many reasons to allow a visit to Durban, according to Palmer. The Sword Knot did have a crew of 65, ten of whom were black, but it was a civilian ship, repairs parts had been sent to Durban already and were waiting installation, the South African government had already given clearance and there was presumably a contract already in place, and any alternative was thought to have been expensive and inconvenient and may have affected their "space capabilities," of the satellite tracking stations run by NASA. In addition, it would be fairly easy to spin positive publicity in domestic media. Finally, and most importantly, Palmer recognized the fact that they needed to have South African cooperation for some time with their tracking stations, use of airfields for a variety of reasons, scientific relationships, and commercial relations. The cons for allowing the ship to dock in Durban included that there would be protesting at home, the repairs were not of an emergency situation, there may be other repair facilities that are easy access, and the South Africans would have a feeling of “indispensability." Palmer clearly leaned towards allowing the Sword Knot to dock in Durban because it had a civilian crew, it would keep South African relations positive for the time being, and the expectation of the crew avoiding segregated activities was feasible. $^{130}$

\footnotetext{
${ }^{130}$ National Archives, General Records of the Department of State, RG 59, "Use of South African Ports," Def 7 SAFR-US, 13 February 1967.
} 
By February 14, the State Department clearly took the stance that it did not want the Sword Knot to dock in Durban. Although it was not confirmed on February 14, the State Department did communicate to the Cape Town Embassy that they were wary of "feeding the fire" of the anti-apartheid feeling that was created by the Roosevelt stop. But, they did specify that diverting the Sword Knot did not necessarily mean that they wanted to discontinue the use of other ports and facilities in South Africa. ${ }^{131}$ Defense Minister of South Africa P.W. Botha made the following statement, as reported by Katzenbach to the Cape Town Embassy:

Acting Secretary in regretting unpleasantness surrounding incident said press attention and hospitality arrangements, no matter how well intended, ballooned event which he had hoped could have occurred in low key. This focused attention here on issue over which most Americans feel very strongly. Fact that Congressional and public opinion came to head at last moment before ship arrived Cape Town made it impossible take any other action than we did. To Mr. Katzenbach's observation that both sides and everyone concerned shared some responsibility for problem, Taswell asserted that SAG had done nothing wrong and had received no complaints from Embassy.

To which Katzenbach replied:

A combat crew has worked together, fought together, taken recreation together. To give them leave in a place where distinctions are made is ipso facto to men themselves, Congress, and others a humiliation. The nub of the problem is South Africa's racial policy itself. ${ }^{132}$

This demonstrates that South Africa continued to play the role of victim in the Roosevelt incident and the policy decisions that followed. This sentiment was preceded by a letter from South African Foreign Minister Muller that reaffirmed the idea that the U.S. approached the South African government with hopes of an integrated visit, with which

\footnotetext{
${ }^{131}$ National Archives, General Records of the Department of State, RG 59, "Sword Knot," Def 7 SAFR-US, 14 February 1967.

${ }^{132}$ National Archives, General Records of the Department of State, RG 59, “FDR Call," Def 7 SAFR-US, 16 February 1967.
} 
South Africa provided and were harshly rejected with such short notice after spending a significant amount of time and resources on providing a good visit. ${ }^{133}$ Whether or not the U.S. was concerned about their feelings of victimhood is unclear, but what is clear is that the U.S. wanted to preserve the use of ports.

The U.S. State Department was stuck in a no-win situation when it came to deciding what to do with the Sword Knot. They were dealing with the fall-out of the Roosevelt stop and the wave of anti-apartheid "hysteria" that followed and they were trying to coddle the South African government, whose cooperation they needed for future port and facility use, despite the fact that they could not connect the U.S. actions to their own misdeeds with apartheid and the past Independence incident.

On February 15, after eight days of waiting in the waters by Durban, a decision was made that the Sword Knot would be rerouted to Mombasa, Kenya. ${ }^{134}$ The South African press immediately reacted to this cancelation. On February 16, the Johannesburg Star reported that the cancelation of the Sword Knot's visit would surely worsen relations between the two countries and would possibly threaten the access of the U.S.'s use of other ports and tracking stations within the country. ${ }^{135}$

An editorial in the Cape Times suggested that the indecision by the U.S. State Department and the lengthy decision-making process showed a weakness not previously seen in the U.S. government. ${ }^{136}$ Not all articles in the South African newspapers were

\footnotetext{
${ }^{133}$ National Archives, General Records of the Department of State, RG 59, "FDR Call," Def 7 SAFR-US, 14 February 1967.

134،"Ship Crew Deplores Incident at Durban,” New York Times, 20 February 1967, pg. 21.

${ }^{135}$ National Archives, General Records of the Department of State, RG 59, "Sword Knot," Def 7 SAFR-US, 16 February 1967.

${ }^{136}$ National Archives, General Records of the Department of State, RG 59, "Sword Knot," Def 7 SAFR-US, 16 February 1967.
} 
negative. The Rand Daily Mail took an anti-apartheid stance on the issue and suggested that rather than pointing fingers, that the South African government look at its policies and truly understand the full impact it was having on international policies of other countries. $^{137}$

Kenya's reception of the Sword Knot was not as warm as the U.S. State Department would have liked, especially given the conflict around their preferred use of, but highly debated, South African ports. Ambassador Glenn W. Ferguson, of the Nairobi Embassy, warned the State Department that the United States should not play up the hospitality of the Kenyans opening their port to the Sword Knot. Ferguson warned, "Reason is that Kenya, as independent African nation, is sensitive to allegations of being partial to West and US." More specifically, because the ship was carrying material for the tracking stations in South Africa, they did not want to be seen as harboring the U.S. during the Cold War. ${ }^{138}$ Kenya did not want to get embroiled in the Cold War or be known as a western-friendly country, which potentially could have been a problem should the U.S.'s space program or military need their ports again in the future. Which sub-Saharan country could they rely upon with dry docks that could handle warships and aircraft carriers of their capacity? This must have made the U.S. nervous about future ships needing to dock in the region.

Furthermore, Katzenbach said that Kenyans were very concerned by how serious the U.S. Executive branch was in fighting apartheid. They did not trust the level of

\footnotetext{
${ }^{137}$ National Archives, General Records of the Department of State, RG 59, "Sword Knot," Def 7 SAFR-US, 17 February 1967.

${ }^{138}$ National Archives, General Records of the Department of State, RG 59, "Swordknot," Def 7 SAFR-US, 17 February 1967.
} 
association the U.S. had with South Africa and felt that they themselves had sacrificed more than the U.S. to fight apartheid, such as ceasing sales of soda ash to them. ${ }^{139}$ The U.S. found themselves potentially losing an ally that could help them with docking and repair needs of large ships and aircraft carriers because of their association with apartheid.

The Roosevelt stop forced the State Department, military, and Congress to establish their stances on the future of South African-U.S. relations, as was already previously seen in Congress when Representatives used the incident as a temperature gauge of how they felt towards the South African government and specifically being connected to a country that openly touted their use apartheid. Shortly thereafter, Arthur Goldberg, the lightening rod of much of the negative press around the incident, spoke out about what the U.S. policy should be. In a letter to Secretary Rusk, Goldberg laid out his rationale for his desire for the U.S. to break their ties to South Africa. Allowing the Roosevelt to even dock in Cape Town showed a relaxation of the U.S.'s stance on apartheid in the direction of acceptance. If the U.S. really wanted to exert influence over South Africa, they should have exploited South Africa's fear of isolation, which was so clearly expressed in the incidents with the ships. This would be much more effective than trying to tempt them into submission by offering them tokens of friendship if they made the right political choices. Thus, Goldberg proposed an immediate disengagement

\footnotetext{
${ }^{139}$ National Archives, General Records of the Department of State, RG 59, "Sword Knot," Def 7 SAFR-US, 21 February 1967.
} 
from South Africa militarily and scientifically, namely in the tracking stations used by NASA and the military. ${ }^{140}$

Goldberg was not alone in asking for a clarification in policy and gladly giving his own interpretation of what should happen. On February 15, Representative Julian Bond of Georgia, wrote to President Johnson. In his letter he asked the President to open up an inquiry into why the visit was allowed to happen in the first place. In addition, he berated the State Department for not only showing "indifference" towards South Africa's use of apartheid, but he was appalled by Rountree and Katzenbach's apologies to the citizens of Cape Town who opened their homes and communities to them, despite the fact that these private functions were allegedly segregated. Ultimately, he asked that the use of ports be reviewed and rejected, as he felt that the U.S. should not show military allegiance to countries that do not uphold the basic idea of human rights for all of its citizens. On February 25, Bond got an answer from Palmer on behalf of the President. In the letter, Palmer restated why South African ports were used, which was that there were "strong operational reasons" for refueling at that particular port and that they only stopped because integrated activities and leave were guaranteed by the South African government. However, with that being said, on February 21, it was decided that South African ports would not be used by U.S. Naval warships, barring any sort of emergency and that further use of the ports was being reviewed. ${ }^{141}$

\footnotetext{
${ }^{140}$ National Archives, General Records of the Department of State, RG 59, "Letter to Rusk" Def 7 SAFRUS, 17 February 1967.

${ }^{141}$ National Archives, General Records of the Department of State, RG 59, "Letter to the President from Julian Bond," Def 7 SAFR-US, 25 February 1967.
} 
It should be noted that this was a form letter sent out to other members of Congress or government that expressed their concern about the use of the ports, thus indicating an official State Department position. For example, Representative Lester L. Wolff (D-NY) wrote to the President and received a letter that had parts of the letter sent to Bond stated verbatim, however it was signed by Douglas MacArthur II, the Assistant Secretary for Congressional Relations. ${ }^{142}$

\section{The Roosevelt in the Global Cold War:}

There is an absence in this issue, which is that of the concern of the direct threat of the Soviets in the region. Granted, South Africa was looked upon favorably for the fact that it offered highly technical ports and was a great alternative to the Suez Canal should there be another situation involving the closure of the canal. However, the Soviet threat is not apparent in the documents available, thus making it is easy to forget that their presence existed in the first place. While it may seem irrelevant to raise the issue of the global Cold War in relation to the Roosevelt and Sword Knot stops, it is actually very relevant as it is easy to jump to the conclusion that most U.S. decisions, if not all international decisions, were made with the threat of the Soviets spreading their influence to particularly volatile countries during this time period.

A side note that offers a brief moment of closure and clarity involved private aircraft. In a memo from the President Johnson's Special Assistant Walt Rostow to Johnson himself dated April 19, 1968, Rostow raises the issue of whether or not civilian

\footnotetext{
${ }^{142}$ National Archives, General Records of the Department of State, RG 59, "Letter to the Dean Rusk from Lester Wolff," Def 7 SAFR-US, 27 February 1967.
} 
aircraft should fly into or through South Africa. Katzenbach suggested that an addendum be added to the 1947 U.S.-South African Air Transport Agreement. Essentially, the amendment would enable South African airlines to fly to the U.S. for the first time, probably to New York, by the end of the year. In addition, the U.S. could fly to South Africa. TWA and Pan American both agreed to the plan because it was a "very good economic bargain for the U.S.”

However, there was a political hurdle. The UN General Assembly passed a resolution in 1962 without U.S. support that requested that all member nations refused landing and passage facilities to South African aircraft. Thus, Rostow predicted that there would probably be some backlash from the UN community, in particular from the African states. However, South Africa did fly its airline through UK, France, German, Italy, Switzerland, Australia, and other industrial countries at the time of this memo. In addition, Rostow checked to see if there would be a huge objection from the Legislative branch and he found that there would be little to no domestic opposition. He asked Johnson to determine if he agreed with the amendment. Johnson checked off that he did agree with the amendment, thus opening up air traffic between the U.S. and South Africa. $^{143}$

To further substantiate the claim that the Soviet threat was minimal at best, the National Intelligence Estimate of 1967 makes no mention of fear of Soviet expansionism in South Africa. Instead of worrying about the threat of spreading Soviet influence, the U.S. government was concerned about racial policy and what that would amount to

\footnotetext{
${ }^{143}$ Memorandum From the President's Special Assistant (Rostow) to President Johnson,19 April 1968, FRUS 1964-1968, XXIV [data base online].
} 
domestically over the next five years in relation to economic development of the black African population and the access to living amenities. It appears that South Africa did want to improve relations with the U.S. State Department particularly after the rocky few months following the U.S.S. Roosevelt incident, thus further illustrating that the South African government had no intention of allowing any sort of communist influence into their country, especially if it meant jeopardizing the remains of their relationship with the U.S. government. ${ }^{144}$

Allowing the docking of the USS Independence, Franklin Delano Roosevelt, and Sword Knot was reliant more on future use of ports and bad press, rather than of concern for U.S. soldiers potentially being subjected to apartheid. With the inauguration of Hendrik F. Verwoerd, an archetypal apartheid advocate, came an attempt to restrict black U.S. crews from using South African ports. In May 1965, the U.S. was scolded publicly by Verwoerd for not only allowing planes with black crews to use airbases, but also because the U.S. Embassy held mixed-race functions, a clear violation of apartheid policy. Rather than taking a stand, the U.S. continued to dock ships and land planes in South Africa until it became an issue when a mixed race American crew returning from Vietnam requested ship leave in February 1967.

The docking of the Roosevelt prompted anti-apartheid advocates in the U.S. to question what the U.S. was going to do from there on out. What would U.S. diplomatic and military policy be for using naval and air bases in South Africa? After restricting the crew from leaving the ship, the State Department, Congress, and Department of Defense

\footnotetext{
${ }^{144}$ National Intelligence Estimate, 4 May 1967, FRUS 1964-1968, XXIV [data base online].
} 
took to discussing future policy. Access to the ports was a far higher of priority to the U.S. for a variety of reasons. South Africa's ports were capable of serious maintenance should the U.S. need it on any of its ships or planes. Also, access to the Cape Route was important to maintain should the Suez Canal become restrictive to the west again in the future. Only Congress reflected any serious concern for the friendly relations with apartheid the U.S. essentially maintained in allowing ships and planes to dock in South Africa. Serious questioning from the Civil Rights community prompted form letters to be sent out on behalf of the State Department insisting they were working on the problem.

Was the decision to maintain access to ports and the Cape Route based on the global Cold War? Yes, but not in the traditional sense of keeping communism from penetrating the borders via black opposition groups, such as the ANC and its armed wing the Umkhonto. South Africa was strategically placed and had technological advancements that allowed them to be a good ally for geographical and strategic reasons, rather than preventing the spread of communist influence. When the U.S. government received criticism domestically and internationally it was for its heavy reliance on the South African government, who had been denounced by the international community for its domestic policies. Little is mentioned in the documentation to contextualize the situation into the global Cold War, unless one looks at the South African perspective. From their perspective, they were fearful they would lose the U.S.'s ship and plane business. When they discussed future relations with the U.S. they liked to promote themselves as being vital to the effort against the Soviets in the global Cold War, particularly in preventing the spread of communism into South Africa. Yet, the reality 
was that Washington was not primarily concerned with this, rather they wanted to maintain port access without international flack. 


\section{Chapter Three: Tracking Stations}

A second case study that highlights the complexity of U.S.- South African relations was the use and employment of the tracking stations in South Africa. This was a contentious issue because of the implications of a potential airfield and ship docking ban by the U.S. government after the Roosevelt incident, but also because at installations that represented U.S. interests for military and scientific realms apartheid was used to its fullest application.

Between 1949 and 1957, the Soviet Union had managed to create and maintain an impressive space program, one that clearly threatened the U.S for valid reasons. In 1949, the Soviets successfully created their own atomic bomb. In the early 1950s, they produced long-range bombers. By 1954, they had successfully tested a hydrogen bomb. By 1957, they had fired a long-range missile over 5,000 miles. However, the real shock that was concerning for the U.S., from the Executive branch to the common citizen, was the launching of Sputknik into space in October 1957. The Soviets could now launch a nuclear missile anywhere in the world, albeit with minimal accuracy. The U.S. had yet to even launch their first missile into space. ${ }^{145}$

On January 31, 1958, the chief of staff of the Air Force, Thomas Dresser White, delivered a new policy in response to the launching of Sputnik. He stated that for the first time in U.S. history, the homeland was in "mortal danger." The launching of Sputnik eliminated the safety of the Atlantic and Pacific Oceans that helped largely thwart any all-out assaults on the U.S. since the civil war. He said, "AAmerica's answer to the Soviet

\footnotetext{
${ }^{145}$ Rita G. Koman, "Man on the Moon: The U.S. Space Program as a Cold War Maneuver," $O A H$ Magazine of History 8, no. 2 (Winter 1994): 42.
} 
challenge would require the military use of space." "146 Thus, space became vital to the efforts in fighting the domestic and global Cold War with the Soviet Union.

In July 1958, Eisenhower, via Congress's approval, signed a bill that established the National Aeronautics and Space Administration, or NASA. In addition to the establishment of NASA, there was also an overall restructuring of scientific education through the National Defense Education Act in the U.S. in the face of vulnerability that Sputnik brought with it. ${ }^{147}$ NASA essentially acted as a consolidating effort of all the diverse programs and interests in space exploration within the U.S. NASA's importance was heightened even further when in April 1961 Russian cosmonaut Yuri Gargarin was launched into space and orbited around the Earth. Newly inaugurated President Kennedy was threatened by this major development and successfully lobbied Congress to double the space budget and vowed to place a man on the moon before the Soviets could do it. ${ }^{148}$

The German V-2 rocket, most notable for reigning terror on the British during WWII, was key to space exploration, along with the scientists that developed them. A major spoil of the war was German rocket technology for both the U.S. and the British. At a Bavarian ski resort, Garmisch-Partenkirhcen, Werner von Braun and his fellow scientists who were responsible for the procurement of the guided missile system were interrogated at length by the U.S. and British. It was at this locale that "Project Overcast" was launched by the U.S. Joint Chiefs of Staff in which 350 German specialists were hired to help develop a more advanced U.S. missile system. Von Braun worked with the

\footnotetext{
${ }^{146}$ Helen Caldicott and Craig Eisendrath, War in Heaven: The Arms Race in Outer Space (New York: The New Press, 2007), 3-4.

${ }^{147}$ Gene Kranz, Failure Is Not an Option, (New York: Berkley Books, 2000), 15-16.

${ }^{148}$ Komen, 42-43.
} 
U.S. to come up with a list of no fewer than 115 scientists that could help develop the U.S. program for the following 6-months. When the Soviets learned of this, they were disappointed to not have gotten von Braun for themselves. ${ }^{149}$

Von Braun and his group of scientists started work immediately in April 1946 in White Sands Proving Ground, New Mexico, with the launching of V-2 test missiles. The Germans were surprised and frustrated with the lack of advancement the U.S. had in their development facilities. The group of scientists were kept in this location not only to work on the V-2 missiles, but to also keep them away from the Nazi war crime trials that were unraveling at Dachau in $1947 .^{150}$

The scientists were moved to Huntsville, Alabama in 1950 by the Army where they would become the preeminent rocket development group in the U.S. It was here under von Braun's leadership that the group developed the nuclear-tipped Redstone and Jupiter missiles of the 1950s. The Redstone became the vehicle to help propel the first satellite and first U.S. citizen into space. They also developed the Saturn vehicles that helped launch Apollo spacecraft into orbit and put U.S. astronauts onto the moon. ${ }^{151}$

This is not to say that the Soviets who actually occupied the region that the V-2 development program in Germany was located, Mittlewerk, did not benefit from rounding up and exploiting German scientist as well. Between 1951-1954, the Soviets went back to Germany to round up as many scientists as they could and used their knowledge to develop ballistic missile development. The result was the launch of

\footnotetext{
${ }^{149}$ Michael J. Neufeld, The Rocket and the Reich: Peenemünde and the Coming of the Ballistic Missile Era (New York: The Free Press, 1995), 267-268.

${ }^{150}$ Ibid, 270.

${ }^{151}$ Ibid, 271.
} 
Sputnik in October 1957, which rested largely on the use of German technological advancements. $^{152}$

The U.S. saw substantial growth in its space program as it was connected to the military. By 1959, ICBMs had been developed and were being tested under the guidance of von Braun. Also, between 1958-1962, the U.S. developed and tested its ability to knock out spy satellites using nuclear explosions in space. The testing for this became so enormous that the U.S. actually caused considerable damage to the earth's electromagnetic field. For example, in 1962, the U.S. exploded the 1.4 megaton nuclear bomb the Starfish in space. The test was so powerful, 100 times more powerful than Hiroshima, that it knocked out the power grid in Hawaii and disabled three satellites in low-earth orbit. ${ }^{153}$

The development of rockets that could deliver satellites into space was one step. Designing effective satellites was the next. Satellites could serve as spies, targeters, and monitors of arms control agreements. ${ }^{154}$ Satellites also served as a way to maintain peace in that they could monitory the launching of missiles and give the other side ample warning of launches that could harm millions of people. They also provided the means to establish a communication link between the U.S. and Soviet Union via the "hot line" that was put into place $1971 .{ }^{155}$

In the early 1960s, the U.S. launched a system of spacecraft called the Vela Hotel program, whose purpose was to detect nuclear explosions in the atmosphere. This system

\footnotetext{
${ }^{152}$ Ibid, 272.

${ }^{153}$ Calidocott and Eisendrath, 9.

${ }^{154}$ Ibid, 8-9.

${ }^{155}$ Ibid, 11.
} 
was highly reliable and durable. It helped the U.S. track what weapons were being tested, how strong they were getting, and, ultimately, who had the ability to detonate a nuclear bomb. ${ }^{156}$

\section{South Africa and the Space Program:}

International cooperation would play a vital role in enabling the growth of NASA. More specifically, NASA worked with the Committee on Space Research (COSPAR) of the International Council of Scientific Unions to achieve military prowess in outer space. COSPAR was created in 1958 to provide "an apolitical venue for cooperation in outer space." Its main purpose was to allow scientists from across the globe to work with one another despite military or political rivalries that existed among various states. ${ }^{157}$ South Africa was a member of COSPAR.

South Africa would play a noteworthy role in this lofty goal. Even prior to the creation of NASA, the U.S. State Department looked to South Africa for land and support in the form of Minitrack radio tracking stations in Esselen Park, agreed upon on October 11, 1957 (the agreement was made by the United States Naval Research Laboratory) and the Baker-Nunn camera optical tracking station located at Olifantsfontein, established in February $1958 .^{158}$

South Africa had nearly a decade of importance in the U.S. science community prior to the Roosevelt incident, thus they were rooted in their success, at least marginally.

\footnotetext{
${ }^{156}$ Paul B. Stares, Space and National Security (Washington, D.C.: The Brookings Institute, 1987), 27. ${ }^{157}$ Ibid, 5.

${ }^{158}$ National Archives, General Records of the Department of State, RG 59, "The American Ambassador to the South African Secretary for External Affairs,"Def 7 SAFR-US, 13 September 1960, 1-2.
} 
In Pretoria on September 13, 1960, six months after the Sharpeville Massacre, the U.S. and South African governments sat down and signed an agreement about tracking stations to be located in South Africa. The U.S., represented by the NASA, and South Africa, represented by the Council for Scientific and Industrial Research (CSIR), agreed to work together to advance their "mutual scientific knowledge" of space and the development of space vehicles, including manned vehicles. ${ }^{159}$

The 1960 agreement ensured U.S. access to key tracking stations. Essentially, the South African government gave the U.S. access to various facilities for NASA and the military at no cost to the U.S. government in exchange for scientific collaboration. Rules pertaining to the admission of U.S. citizens into South Africa to work on the sites were established. The agreement stated:

The Government of the Union of South Africa will, subject to its immigration laws and regulations, take the necessary steps to facilitate the admission into the territory of the Union of South Africa of such United States personnel... to visit or participate in the cooperative activities provided for under this agreement.

This obviously became an issue with the Independence incident in 1965 in which the South African government clearly stated that the U.S. must follow all laws established under apartheid. The program was intended to last for up to fifteen years and had the possibility of extension based on the agreement of both parties. ${ }^{160}$

South Africa became a key spot geographically for NASA, particularly during the Apollo and Mercury missions. Cape Canaveral was the central point for which other stations were established, as it was often used as a launch point. Originally,

\footnotetext{
${ }^{159}$ National Archives, General Records of the Department of State, RG 59, "The American Ambassador to the South African Secretary for External Affairs,’Def 7 SAFR-US, 13 September 1960, 1.

${ }^{160} \mathrm{Ibid}, 3$.
} 
Johannesburg was picked by NASA as a third-tier tracking station because it allowed for the determining of the initial orbit of satellites. Other stations in this tier (the first and second tiers formed direct "picket lines" north, south, east and west of Cape Canaveral) included San Diego and Woomera, South Australia. All of the stations were staffed by military personnel from the Army and Air Force except for the one in Johannesburg, which was staffed by the CSIR and NASA personnel. ${ }^{161}$

In 1957, a Minitrack station was opened in Johannesburg, a less sophisticated site to track satellites in that it required a satellite to submit some sort of signal source or transmitter beacon, so that radio signals could be sent out and picked up by the Minitrack stations, thus allowing for an accurate tracking of location. ${ }^{162}$ However, in 1960, work began on a much more sophisticated Satellite Tracking and Data Acquisition Network (STADAN), which allowed for tracking to evolve from the use of radio frequency for tracking to the use of optics. As NASA shifted from Minitrack to STADAN, their location of stations shifted. Tiers mentioned previously were no longer relevant, but South Africa was largely untouched and remained in existence until $1975 .{ }^{163}$

In addition to Minitracking and STADAN capabilities, Johannesburg also had Deep Space Network (DSN) and Satellite Automatic Tracking Antennae (SATAN) capabilities as well. ${ }^{164}$ DSN was a program created as early as 1958 and allowed for the exploration of unmanned planetary missions and radio and radar astronomy in the exploration of the solar system and the universe through the use of telecommunications

\footnotetext{
${ }^{161}$ SunnTsiao, "Read You Loud and Clear!": The Story of NASA's Spaceflight Tracking and Data Network, (Washington D.C.: NASA History Division, 2008), 18-19.

${ }^{162}$ Ibid, 9,11 .

${ }^{163} \mathrm{Ibid}, 39-40$.

${ }^{164}$ Ibid, 55-56.
} 
and radio navigation networks routed around the world. ${ }^{165}$ SATAN replaced Minitrack units with more efficient and cheaper large dish antennas that were used to make satellite tracking possible. ${ }^{166}$ The Johannesburg station was critical not only because it was one of the few stations to have DSN and STADAN, but also because it was essential to the success of the DSN because it allowed NASA to maintain continuous coverage of space probes as they departed the planet and rotated the earth. ${ }^{167}$

Even prior to the Independence incident in May 1965 when Prime Minister Verwoerd began putting stipulations on crews to follow apartheid and not to allow black crewmembers onto racially segregated bases, there was discussion about the importance of the Johannesburg station. The Director of the Office of International Scientific Affairs, Ragnar Rollefson, told the State Department that Southern Africa was very critical to the success of NASA, in combination with launch sites in California and Florida. Southern Africa was on the same parallel, which was essential for support. South Africa and Madagascar at the time both had tracking stations, but South Africa was clearly more essential to the efforts as it was located on the same parallel. The facilities were used for long-range missile testing, tracking earth orbiting unmanned satellites and lunar and planetary probes, and tracking earth orbiting and lunar manned flights in the Apollo program. Rollefson warned about getting rid of the facility that would help ensure its existence until 1975:

This office had concluded that this continued use and extensions of ground facilities (tracking, data acquisition and command stations) under U.S. control in the area of Southern Africa over the next five years is a critical requirement, if the

\footnotetext{
${ }^{165}$ Ibid, xiii.

${ }^{166}$ Ibid, 39.

${ }^{167}$ Ibid, 207-208.
} 
United States is to carry through the space program to which it is committed within this decade... there is no satisfactory alternative. Failure to meet this requirement will be costly in time and money. More important, it will jeopardize the success of key space missions and may, in the long run, damage the image of the U.S. technological and scientific achievement which we seek to foster abroad through a successful space program.

Essentially, South Africa was the only viable option to help run a successful space program. $^{168}$

This recommendation came on the heels of turbulence involving access to other African stations that could have been useful in tracking. Johannesburg was not the only station in Southern Africa. Zanzibar also had a station that was essential to STADAN and the Mercury missions. However, in 1960, Zanzibar became politically unstable. By 1963, Zanzibar was facing pre-civil war tensions. There were elections in 1963 and Zanzibar gained independence. It ultimately merged with Tanganyika and formed Tanzania, but the transition was not as peaceful as NASA would have like. NASA feared that political tension could turn into hostility in a moment's notice and put into place an evacuation plan should it come to that. In 1964, the station was ordered to be evacuated, thus one of the alternatives for tracking was eliminated. ${ }^{169}$

Johannesburg was also protected by Rollefson because it was assigned to provide support for the Apollo mission in a backup or standby capacity. ${ }^{170}$ President Kennedy had given NASA a significant goal in putting an American on the moon by 1970 and NASA was determined to meet this goal. The Gemini missions significantly helped get

\footnotetext{
${ }^{168}$ Memorandum From the Director of the Office of International Scientific Affairs (Rollefson) to the Assistant Secretary of the State for African Affairs (Williams), 9 March 1964, FRUS 1964-1968, XXIV: 971-972.

${ }^{169}$ Tsiao, 124-125.

${ }^{170}$ Ibid, 149.
} 
the U.S. within a stone's throw of achieving this goal. Gemini saw a series of firsts- the first two-man flight, the first spacewalk, the first docking, and the highest orbit to date (850 miles above Earth). ${ }^{171}$ Thus, Apollo became the central element to the goal of walking on the Moon.

The goal with Apollo was not only to land on the Moon and have a successful exploration of its surface, but to have the ships reenter Earth's atmosphere successfully and safely. This would require the best tracking possible with no possibility of interruptions or failures from the Earth's bases. ${ }^{172}$ Thus, in 1964, Johannesburg received a $\$ 5$ million expansion to make it ready for the Apollo mission. ${ }^{173}$ So, it is no wonder that Rollefson was urging the U.S. State Department and Congress not to give up on the South African station, particularly in the next five years when it was projected that a man would land successfully on the Moon.

The renewal of the tracking stations, which were originally set to expire on March 31, 1962, was tied indirectly into the sale of weapons to South Africa. (The reason for the sale of weapons to South Africa will be addressed in depth in the next chapter.) In a secret memo sent from the embassy in Cape Town to the State Department on June 15, 1962, it was revealed that part of the deal for allowing NASA's and the U.S. military's access to the tracking stations was tied into the South African government's desire to buy weapons:

In the latter the view of the South African government was expressed that an arrangement in connection with the military tracking station operations be "accompanied by an understanding that the United States would give more

\footnotetext{
${ }^{171}$ Ibid, 141.

${ }^{172}$ Ibid, 143-144.

${ }^{173}$ Ibid, 208.
} 
prompt and sympathetic consideration to reasonable requests for the purchase of such military equipment as may be required for South Africa's defence."

In the memo, it specifically stated that while the U.S. was "prepared to give an assurance on military procurement, it would prefer that this question not be included in the proposed exchange of letters covering the tracking station." Weapons were clearly tied in at some level with access to the tracking stations- to what degree is unclear, but the connection is undeniably present. The Ambassador was therefore allowed to make the following official statement to the South African government during negotiations:

The United States Government has in the past indicated its willingness to cooperate with the South African Government in defense against international communist aggression and to sell military equipment for this purpose. Taking into account, of course, technical questions of availability, security, and engineering compatibility, the United States Government can assure the South African Government that it will give prompt and sympathetic attention to reasonable requests for the purchase of military equipment required for defense against external aggression. ${ }^{174}$

Keeping access to the tracking stations on behalf of NASA and the military was of clear importance to the State Department. It was important enough to risk public ridicule for selling weapons to South Africa, despite the embargoes that were put into place by the U.S. and U.N. to prevent weapons from going to South Africa. South Africa was geographically too important of an ally in fighting the larger global Cold War against the USSR.

On April 26, 1964, National Security Action Memorandum No. 295 was handed down on behalf of the request the State Department made on March 10, which asked for a policy paper on South Africa. In NSAM No. 295 stipulations were set for U.S. policy

\footnotetext{
${ }^{174}$ National Archives, General Records of the Department of State, RG 59, “Memo from Cape Town,”Def 7 SAFR-US, 15 June 1962.
} 
toward South Africa. This included the need to develop a comprehensive program of diplomatic activity, continue sales to South Africa (except submarines), discontinue loan applications by South Africans from U.S. government lending agencies, and to continue the use of tracking stations in South Africa by NASA and the Department of Defense but should prepare alternative stand-by stations should they need to leave South Africa. With this last stipulation, an interesting and telling stance was taken towards continuing the relationship with their tracking stations:

This program shall be carried out in such a manner as to avoid its coming to public notice as long as feasible, and in close consultation with the Department of State particularly so that the public aspects and the diplomatic aspects of our relations with South Africa may be coordinated. ${ }^{175}$

Again, there was a foreshadowing of the political pitfalls that could follow the revealing of the nature of this program within the South African government due to the precarious nature of having any sort of important alliance with South Africa.

This same memo looks at the reality of possibly giving up the South African station and shifting the tracking burden to the Tananarive (Madagascar) station in case there was a need to walk away from Johannesburg. Based on geographical location, workload, communications capabilities, U.S. and foreign staffing needs and cost, Johannesburg was by far the more desirable station. Johannesburg provided the first major land mass that would be encountered by ships leaving Cape Canaveral (in the memo it is referred to as Cape Kennedy), whereas Tananarive was much further away. Cape Canaveral is located at $28^{\circ} \mathrm{N}$, Johannesburg is located at $26^{\circ} \mathrm{S}$, which was deemed a very "compatible" latitude of Cape Canaveral; however, Tananarive is located at $19^{\circ} \mathrm{S}$,

\footnotetext{
${ }^{175}$ National Archives, General Records of the Department of State, RG 59, "National Security Action Memorandum,'Def 7 SAFR-US, 26 April 1964.
} 
which did not have nearly as much satellite traffic overhead as Johannesburg. This was clearly very crucial to the STADAN requisites.

Johannesburg was also more reliable in the communications department because of improvements made by the South African government's installation of a submarine cable, which would have allowed for a $99.8 \%$ reliability for communications. Johannesburg did not require a large number of U.S. staffing, as the CSIR provided a highly competent staff, whereas Tananarive required a much larger number of U.S. personnel, which would cost three times as much as the Johannesburg station. The Johannesburg station was financially and technically more sound of a choice for a sustainable STADAN station. More importantly was that Johannesburg also had DSN capabilities, which was irreplaceable at the Tananarive station. In fact, NSAM No. 295 clearly states, "Loss of the Deep Space Station in South Africa would significantly injure the space program." Thus, despite the political pressures that existed with being reliant on South Africa for anything, it was recommended for technical reasons that the Johannesburg station be kept open and operational. ${ }^{176}$

There was a concern that if the South African government caught wind of the NSAM No. 295 recommendations to be able to move out of Johannesburg with sixmonths' notice, that there would be an undesirable downfall for relations with the U.S. In a status report on NSAM No. 295, the Department of State was happy to see that alternative space tracking facilities in Tananarive, Spain, and Ascension Island were being prepared, but they were worried that the South African government would figure out why they were building alternative sites. They wondered if they should inform South

${ }^{176}$ National Archives, "National Security Action Memorandum." 
Africa about the other sites' existence. ${ }^{177}$ But, the reality was the State Department, Department of Defense, and NASA did need alternatives to Johannesburg because there was a clear worsening of racial relations in South Africa that could potentially isolate the U.S.'s international position and pose major problems for U.S. foreign policy. ${ }^{178}$ This was of course about to be tested with the Independence and Roosevelt incidents, which clearly brought U.S. relations with South Africa into the spot light for an uncomfortable amount of time.

\section{Independence and Roosevelt:}

The Independence incident has already been discussed at length in terms of its impact on naval ports and airfield use by the U.S., but what impact did it have on the tracking stations? On July 4, 1965, the New York Times reported at length about a speech given by Prime Minister Verwoerd in which he said that integration was not a problem in the U.S. where black men were outnumbered ten to one, but it was in South Africa where white men were outnumbered five to one. Integration would have meant the end of South Africa as a nation. "The result would be black rule and the result of black rule would be Communism." This was a common statement made by various government officials in South Africa when discussing their importance to the U.S. They often used the idea of a communist take-over in the same breath when discussing the end of white apartheid rule. This same New York Times article dissected what this meant for the critical tracking

\footnotetext{
${ }^{177}$ Status Report on NSAM No. 295 of April 24, 1964- South Africa, 30 July 1964, FRUS 1964-1968, XXIV: 997.

${ }^{178}$ National Policy Paper- South Africa. Part One- US Policy, 18 January 1965, FRUS 1964-1968, XXIV: 1007.
} 
stations located in South Africa. Verwoerd specifically said that no black U.S. citizens would be permitted to work on the tracking stations at any time. NASA and the Department of Defense had never assigned black citizens to work there and never had intended to do so. The New York Times put more emphasis on the tracking stations than the port call by the Independence:

But the tracking stations were far more important than a single port of call. There can be no doubt that their removal would have had a tremendous impact here, shaking the confidence of investors and bringing the two Governments to the point of outright mutual hostility. This was what neither side wanted. ${ }^{179}$

It is unlikely that this sparked any sort of U.S. public outrage towards the tracking stations, as very little was known about them at this point by the public.

There is no doubt that urgency was added to the NSAM No. 295 with the Independence incident. Having other stations that STADAN and DSN could use "just in case" were no longer just in case. A real threat was the possibility of South Africa terminating its space-tracking agreements with the United States, which was very stressful to NASA in particular because of the progress of Apollo and the need for South Africa as a tracking station. The State Department was clearly concerned for how they were perceived in the international arena:

In addition to their concentrated efforts to persuade the United States and others to institute economic and military sanctions against South Africa, the Afro-Asians have sought the termination of all agreements with South Africa, specifically citing our space facilities, which might in some way encourage South Africa's pursuit of its present racial policies.

But, there was a minor voice that was beginning to be heard in that the tracking stations could potentially be an important card to play at a later point with South Africa should

179،"South Africa Asks White Guests Only,” New York Times, 4 July 1965, pg. E8. 
the need arise. The U.S. would be ready with alternative situations should the attempt at vis-à-vis diplomacy fail. ${ }^{180}$

NASA was clearly very concerned about the situation the Independence presented. But they were very frank with the State Department during the midst of this crisis. NASA stated very clearly that the State Department had a choice: either they could move the stations to Spain and Tananarive, where other tracking stations already existed, and put the space race on hold or they could leave the stations as is and stay on track for a lunar landing by 1970 and hope for the best politically. Also, there was some delay in getting the Spanish tracking station established to be operational within the next six months, which made the South African station more critical for DSN. ${ }^{181}$

Several weeks later the Administrator of NASA, James E. Webb, made it very clear to Secretary of State Dean Rusk that closing down access to Johannesburg was not ideal, not because of geography, but because of the capabilities of the different stations. The Madrid facility could only handle one mission at a time, which would severely slow progress down on Surveyor missions and Orbiter mapping missions. In addition several unmanned missions needed to be launched to ensure the success of Apollo and the closing of Johannesburg would severely delay this process and make it impossible to land a lunar mission on the moon by the end of the decade. More importantly, Webb issued a warning hard to ignore:

\footnotetext{
${ }^{180}$ Comments on Status Report on NSAM No. 295 of April 24, 1964, No Date, FRUS 1964-1968, XXIV: 1043.

${ }^{181}$ Memorandum From the Assistant Administrator for International Affairs, National Aeronautics and Space Administration (Arnold W. Frutkin to the Assistant Secretary of State for African Affairs (Williams), 14 December 1965, FRUS 1964-1968, XXIV: 1045.
} 
... the USSR has already launched four spacecraft in a vigorous effort to achieve a successful unmanned lunar soft landing. Further delays in the Surveyor schedules would strongly reinforce their chances of being the first to accomplish this important mission, which would attract a great deal of attention.

The earliest the Madrid facility would be ready would be in February 1967, thus South African facilities would have to be maintained at least until early 1967 when Madrid would be ready. ${ }^{182}$

In addition, NASA found South Africa to be the most favorable spot for a variety of reasons and did not want to give it up. In addition to all the previously mentioned reasons, they favored the Johannesburg station because "it was actually the most democratic and most stable government [emphasis author's own] accessible to the United States on the continent at the time." ${ }^{183}$ NASA pointed out the inevitable scenario that presented itself- the U.S. State Department found itself between a rock and a hard place. Should they risk their international reputation by continuing to do political and scientific business with South Africa or should they take actions that would delay a goal stated by the late President Kennedy to land a man on the moon by the end of the decade (and before the Soviets in the highly politicized space race)?

The Roosevelt docking in February 1967 posed the second major challenge to NASA's attempts to hang onto Johannesburg. With this much-publicized event came cries from the public, the civil rights movement, and other government officials to establish some kind of clear policy towards South Africa and the use of ports, airfields, and bases. The conversation began immediately in the State Department and Department

\footnotetext{
${ }^{182}$ Memorandum From the Administrator of the National Aeronautics and Space Administration (James E. Webb) to Secretary of State Dean Rusk, 15 January 1965, FRUS 1964-1968, XXIV: 1046-1047.

${ }^{183}$ Tsiao, 208-209.
} 
of Defense. On February 21, 1967, Deputy Secretary of State Cyrus Vance requested a prioritization of Department of Defense requirements for use of South African ports, yards, airfields, and real estate to the Joint Chiefs of Staff. He specifically wanted to know how essential South African ports and yards were for U.S. Naval war ships and any other ships or vessels essential to Defense operations or under contractual obligation to satisfy Defense and NASA requirements and how essential land-based tracking facilities were. He also requested that they come up with alternative plans to satisfy all Defense requirements should South African ports, airfields, and tracking stations become unavailable. ${ }^{184}$ As was discussed in the previous chapter, the Joint Chiefs of Staff all felt very strongly about retaining the right to use South African ports, especially if the Suez Canal was unavailable for use.

On February 7, 1967, Rountree made the implications of the Roosevelt decision to keep soldiers from engaging in leave clear to the State Department. He stated the tough political position the U.S. found themselves in quite nicely:

In terms of our concrete defense interests in SA, we are concerned that the FDR decision may render it extremely difficult for us to justify or permit other naval visits which have taken place on more or less routine basis.... Further cases in point are our project magnet flights and MAC flights in support of space tracking stations. Obviously, tracking stations themselves present important policy question.

This highlights the immediate importance and concern there was for the space tracking stations. In the face of blanket diplomacy, the U.S. had a lot to lose in South Africa.

\footnotetext{
${ }^{184}$ DoD Requirements for Facilities and Contractual Support in the Republic of South Africa, 21 February 1967, FRUS 1964-1968, XXIV: 1070.
} 
Furthermore, Rountree did offer his assistance as he knew that the U.S. was facing some immediately tough consequential decisions as handed down by the Roosevelt ruling. ${ }^{185}$

The Sword Knot issue, which arose immediately after the Roosevelt, was also very concerning to the U.S. State Department because it not only called for an immediate policy decision, but it also called for the government to actually enforce it and face the real reaction by the South African government to a more stringent policy regarding the ships. On February 12, 1967 the Cape Town Embassy communicated with the State Department that the implications of the Roosevelt decision were about to become very evident. In regards to the Sword Knot and the possibility of diverting it to another port, the U.S. State Department feared how the South African government would react. They feared that their action might be interpreted as the "beginning of end to all Naval calls." The Embassy said that diversion at this point could potentially be more costly than dealing with the domestic fall-out of the racial implications. They stressed that if the South African government felt this was a beginning to an end that the South Africans would "be far less cooperative than heretofore with respect other U.S. military and space projects in connection with which we have in past had very few problems."186 This was a warning that the State Department was surely not to take lightly, especially given the pressure of the space race and the importance that NASA afforded that particular space station in the years' past.

\footnotetext{
${ }^{185}$ National Archives, General Records of the Department of State, RG 59, “Cape Town's 759,"Def 7 SAFR-US, 7 February 1967.

${ }^{186}$ National Archives, General Records of the Department of State, RG 59, Department of State Telegram, Def 7 SAFR-US, 12 February 1967.
} 
Being that it was 1967, this was a legitimate fear. The Vietnam War's peak of U.S. troop and political commitment began in 1967 and would last several years thereafter. While it is unclear how often ships going to and from Southeast Asia were traveling by the Cape, it is clear that it had been used by the U.S. Navy for troops and supplies heading to and from the war in Vietnam. Thus, losing such a vital port for its geography and ship repair and docking capabilities could be an issue for troop and supply movement to and from Southeast Asia.

South Africa also sought a clarification in U.S. policy. In a rather harsh message from South African Foreign Minister Bernardus G. Fourie to the Secretary of State sent via the South African Ambassador in D.C. on February 14, 1967, it is apparent that the U.S. concern about the impact of the Roosevelt and future Sword Knot decisions was not unfounded. Fourie said that he was upset and confused by the decision to keep the Roosevelt from docking, especially given the fact that the U.S. asked to dock there and that extensive welcoming plans were laid by the community. He also clearly warned that he did not know what this meant for future cordialness between the two countries and future cooperative exercises in diplomacy and scientific affairs. In addition, he expressed confusion at how large ships would be made to pass South African ports, while smaller ships routinely used their services. He asked for some sort of clear-cut policy by which they could expect the U.S. to follow so that relations between the two countries would not be harmed any further. ${ }^{187}$ Furthermore, in a Johannesburg Star article published on February 16, it was stated that the future of the tracking stations shared by CSIR and

\footnotetext{
${ }^{187}$ National Archives, General Records of the Department of State, RG 59, “Cape Town 784,”Def 7 SAFRUS, 14 February 1967.
} 
NASA were in question due to the vague policy that was tending to lean towards the abolition of use of South African ports. ${ }^{188}$

On February 17, 1967, in the midst of the naval port controversy, Ambassador Goldberg, wrote a letter to Dean Rusk expressing his opinion of what should happen with South African policy. In the letter, he said, in contrast to the Embassy position, that the U.S. government had never really had much of an influence over the South African government and that decisions should be based on this premise. He opposed the idea that closer relations would bring forth more opportunities for the U.S. to influence or guide South African decisions. In his own words, "I estimate that it is her fear of isolation which provides us our best lever in dealing with South Africa and I believe it would be a false step to reassure her of our goodwill." Therefore, Goldberg suggested that the U.S. immediately "disentangle ourselves from remaining military and scientific ties." Specifically, missile and satellite tracking stations needed to be closed immediately and shifted to Madagascar and Spain. ${ }^{189}$

In chapter two, the Sword Knot's docking was looked at length. It is essential to revisit here because the Sword Knot was a carrying parts for the tracking station in Johannesburg. This is a moment where the two case studies of docking policy of naval ships and the use of satellite tracking stations meet. The Sword Knot had eleven U.S. black men on board, but they were not being denied access to the ports, such as the

\footnotetext{
${ }^{188}$ National Archives, General Records of the Department of State, RG 59, "Sword Knot,"Def 7 SAFR-US, 16 February 1967.

${ }^{189}$ National Archives, General Records of the Department of State, RG 59, Letter from Arthur Goldberg to Dean Rusk, 17 February 1967.
} 
Independence in 1965. They docked the Sword Knot in Kenya, and moved the goods over dry land to Johannesburg.

The South African newspaper Die Beeld carried a front-page article on the event shortly after the docking of the Sword Knot in Kenya with the headline proclaiming "Yanks Practice Deceit on our Airfield." The headline was below a picture of a U.S. Air Force plane stationed at the Jan Smuts airfield. The article talked about how the U.S. had no difficulty enforcing apartheid protocol at airfields, but drew a line in the sand around the use of naval ports, which may not have been true, as there are other accounts by the U.S. State Department, as reported by the Embassies in South Africa, that said black U.S. crews did frequent airfields after the Independence incident. The article discussed how the U.S. flights did frequent the airfields to bring in equipment and crew members to help with the satellite tracking stations. ${ }^{190}$ Seemingly separate issues collided head on because of the policy that could potentially be set in ruling that no ports in South Africa should be used by any U.S. vessels. ${ }^{191}$

In addition to dealing with the political repercussions of Roosevelt and the Sword Knot incidents, NASA also was contending with budget cuts required of them by the Legislative and Executive branches. On April 11, 1968, NASA was set to meet at the Inter-Regional Group (IRG) meeting to discuss this issue of budget cuts. NASA proposed to cut the DSN station in Spain and the STADAN station in Madagascar, as Johannesburg had both capabilities and was in a better situated place geographically. The

\footnotetext{
${ }^{190}$ National Archives, General Records of the Department of State, RG 59, "Sword Knot Aftermath," 20 February 1967.

${ }^{191}$ National Archives, General Records of the Department of State, RG 59, “Swordknot,"Def 7 SAFR-US, 17 February 1967.
} 
only problem with this was that the State Department had asked NASA to have alternatives so that there was room for negotiation with the South African government should a vis-à-vis situation arise. ${ }^{192}$

In April 1968, the State Department looked closely at the issue of the budget cuts versus the needs of NSAM-295, which stated that NASA and the Department of Defense needed to have alternate stand-by facilities available for use within six-months' notice should Johannesburg need to be shut down for politically motivated reasons. Johannesburg's station was run by CSIR and employed 237 foreign nationals, 131 of whom worked for STADAN and 106 for DSN. There were only three contracted U.S. citizens there to act as liaison for the DSN network. In contrast, the Tananarive STADAN had 233 employees just for its STADAN station, including 59 U.S. citizens, and Madrid's DSN program staffed 252 people, including five U.S. citizens. Because the Johannesburg station was locally operated by CSIR, NASA would be saving $\$ 520,000$ per year if they did not need to operate the Tananarive station. For budgetary and logistical reasons explained previously, Johannesburg was clearly the most viable option at the time. However, given the political climate, the solution became much more muddled. $^{193}$

There was a significant amount of political pressure to close Johannesburg. On February 17, 1967, Ambassador Goldberg urged that NASA become disentangled from South Africa so that a more stream-lined policy could be put into place towards port and airfield usage in South Africa. He wrote:

\footnotetext{
${ }^{192}$ National Archives, General Records of the Department of State, RG 59, "IRG- NASA Tracking Stations, April 11- 2:30 p.m. Action Memorandum,"Def 7 SAFR-US, 8 April 1968.

${ }^{193}$ Ibid, "IRG-NASA Tracking Stations."
} 
Make a firm and final decision to close our missile and space tracking stations in South Africa and to shift to facilities in Madagascar and elsewhere by this summer at the latest... I would like us at the earliest possible date to free ourselves of the restraints which the continuation of these facilities in South Africa impose upon us.

Goldberg was very uncomfortable with having a potential situation arise where the U.S. would be vulnerable politically to South Africa. In addition to the pressure put on by Goldberg, the UN also did not like the presence of U.S. tracking stations in South Africa and thought of it as "evidence of US-SA military cooperation." Essentially, the domestic and international community were breathing down NASA's and the U.S. government's necks to find a resolution to having a station in Johannesburg. ${ }^{194}$

Ultimately, Clark recommended that the Johannesburg NASA station be closed and that the STADAN and DSN stations in Tananarive and Spain be kept open. His rationale was built on the above considerations by the UN and Goldberg. In addition, he was not concerned about the Department of Defense's use of the facilities because Johannesburg had "reportedly become less than of critical importance since last spring." In addition, he felt the U.S. should retain positive relations with Madagascar and Spain and that closing the site there would reduce critical positions and aid that they relied upon from the U.S. government. ${ }^{195}$

Clark received a concerned phone call from Don Morris, the representative for NASA at the April $11^{\text {th }}$ IRG meeting. After reading Clark's recommendations, Morris called Clark and said that Johannesburg was considerably important to the DSN efforts. After NSAM-295, NASA built a third DSN dish (the first two were in South African and

\footnotetext{
${ }^{194}$ Ibid, "IRG-NASA Tracking Stations."

${ }^{195}$ Ibid, "IRG-NASA Tracking Stations."
} 
Spain, it is unclear where the third one was located) as they needed a secondary back-up dish and should stand-by stations be invoked by the U.S. government, the third dish would be necessary. However, in the light of budget cuts, it would make sense to reduce the operations of the other dishes and keep the South African dish, as it was more essential in DSN. It is important to note, that in a "very much off-the-record comment Don said that he would fight in NASA for a full withdrawal from South Africa, if this were part of a general US disengagement." This meant that if all U.S. interests in South Africa were asked to withdraw, including private businesses such as General Motors, that NASA would also withdraw, but without insurance from the U.S. government that this would happen, NASA would strongly resist any move to challenge Johannesburg. This, of course, prompted Clark to change his recommendations and suggest that NASA capabilities in Johannesburg be severely limited- to the point where only a skeletal reserve is left operational for STADAN, but not necessarily shut down. ${ }^{196}$ NASA kept the station open until 1975. The downfall of the South African station would ultimately be Congressional pressure in the form of a House bill that cut $\$ 3$ million for NASA funding for stations in South Africa. The bill was defeated, but the end had become clear. $^{197}$

NSSM-39:

The conflict with the strategically important bases for NASA was an issue that needed to be dealt with in a quick and efficient manner. This was an issue much bigger

\footnotetext{
${ }^{196}$ National Archives, General Records of the Department of State, RG 59, "Supplementary Briefing, NASA IRG, April 11, ACTION MEMORANDUM,’Def 7 SAFR-US, 10 April 1968.

${ }^{197}$ Tsiao, 211.
} 
than the State Department and its Ambassadors in South Africa and soon thereafter would see the direct involvement of the Executive branch, namely in the form of the National Security Council. The National Security Council (NSC) was a medium for making policy decisions, such as port usage. In order to understand the decision-making process, it is important to understand how the NSC functioned and what its intentions were.

Presidents Johnson and Nixon both saw the need for a strong NSC when they were in office, Nixon especially. On July 26, 1947, President Truman signed the National Security Act of 1947, which created the NSC. Section 101(a) of the act best describes the role of the NSC:

The function of the Council shall be to advise the President with respect to the integration of domestic, foreign, and military policies relating to the national security as to enable the military services and the other departments and agencies of the Government to cooperate more effectively in matters involving the national security.

The council largely consists of the President, Vice President, Secretary of State, Secretary of Defense, and the Secretaries and Under Secretaries of other executive departments, along with the military departments. ${ }^{198}$

The NSC is largely structured by the president in charge. Under President Johnson, influential names in the NSC were Bundy, Rusk, Rostow, and McNamara. Johnson’s NSC sought to deliver a united message from the various departments; essentially, NSC meetings saw the settling of White House infighting before policy was presented to the other departments. ${ }^{199}$ President Nixon's NSC was different. Henry Kissinger, Nixon's

\footnotetext{
${ }^{198}$ David J. Rothkopf, Running the World: The Inside Story of the National Security Council and the Architects of American Power(New York: Public Affairs, 2004), 5.

${ }^{199}$ Ibid, 99-100.
} 
NSC Advisor, was largely responsible for approving policy. In Kissinger's NSC, interagency committees would write National Security Study Memorandums (NSSM) and submit them to the NSC. The NSSMs were supposed to take into consideration potential problems and outcomes of policy decisions. If the policy was sound and agreed upon, they would become National Security Decision Memoranda (NSDM). The NSC was essentially an engine driving U.S. foreign and national security policy. ${ }^{200}$ During Nixon's first term, no fewer than 165 NSSMs were completed. ${ }^{201}$

Kissinger felt that the procedures they put into place were very important. He felt it was important to centralize the decision making and keep secret crucial foreign policy decisions until the time was right to reveal them, if at all. ${ }^{202}$ Kissinger would later comment on his role as National Security Advisor:

'The president sees the security advisor as being at his disposal, representing his interest, whereas the secretary of state is seen as representing the bureaucracy.... After all, the State Department has 180 clients. So they have a lot of things to get done each day which have a necessary priority for them. So the operation of the State Department, for example, is basically answering cables. It is very hard when you are secretary of state to say, the hell with this, now let's talk about long-range problems and work back from that.... It doesn't tell you where to go in the long term. That's what we tried to do. And the security advisor also ends up dealing with and knowing the problems that are of greatest interest to the president- which inevitably has to include all or many or most of the major policy issues. ${ }^{203}$

Kissinger did not deny the enormity of his role and his influence on policy making.

Thus, when looking at policy choices towards South Africa, which Nixon was forced to do immediately upon taking office in 1969 , it is important to keep in mind how the NSC worked and who was at its helm.

\footnotetext{
${ }^{200}$ Ibid, 117.

${ }^{201}$ Ibid, 120.

${ }^{202}$ The Kissinger Study on Southern Africa (Nottingham: Spokesman Books, 1975), 6.

${ }^{203}$ Rothkopf, 118-119.
} 
In April 1969, the NSC was instructed to prepare a comprehensive review of U.S. policy towards Africa. These efforts were headed by Roger P. Morris. What was produced was NSSM-39 in 1969. This was essentially the cornerstone to Nixon's policy in South Africa during the first term of his presidency. ${ }^{204}$ Morris personally believed that no U.S. president should jeopardize U.S. investments in southern Africa. He also felt that economic prosperity would translate into political liberalization, particularly in South Africa. ${ }^{205}$ In addition, he believed that economic sanctions against the South African government would never dismantle apartheid. ${ }^{206}$

Thus, when Morris presented NSSM-39 in December 1969, he had five options for the departments to mull over. (It is important to note that NSSM-39 is a policy toward southern Africa, not necessarily just South Africa). The first option, known as the "Acheson Option," saw the condemnation of white supremacy as excessive and that the U.S. should rather align themselves with the white regimes to help defend U.S. interests politically, militarily, and economically. ${ }^{207}$ The second option called for continued association with white regimes, but also with black governments as well in an effort to enlist cooperation from black states to reduce tension. This option saw to it that the U.S. would also be able to continue persuading white governments through a close relationship, rather than dismissing them as illegitimate and losing any sway over their policy already held. ${ }^{208}$ This option called for relaxing political isolation and economic

\footnotetext{
${ }^{204}$ The Kissinger Study on Southern Africa, 5-6.

${ }^{205}$ Robert Kinlock Massie, Loosing the Bonds: The United States and South Africa in Apartheid Years (New York: Doubleday, 1997), 233.

${ }^{206}$ Christopher Coker, The United States and South Africa, 1968-1985: Constructive Engagement and Its Critics (Durham: Duke University Press, 1986), 17.

${ }^{207}$ Massie, 233.

${ }^{208}$ The Kissinger Study on Southern Africa, 46.
} 
restriction on South Africa. ${ }^{209}$ The third option strictly limited cooperation with white states in an attempt to safeguard its interests in the rest of southern Africa and to help its posture in international politics. It also called for more aid to go to southern African states that were now led by black governments. The fourth option called for the dissociation of relations with white governments and closer relationships with black states. The fifth option saw the severance of ties to both sides in the racial conflict in South Africa because it was unmanageable and potentially dangerous and would eventually grow into a political nightmare on the international stage for the U.S. government. $^{210}$

The NSC and State Department clashed over which option was the best. The third option was favored by the State Department, as they felt that following the wishes of the black majority in South Africa would best suit U.S. interests. Morris favored option two over option three because he felt that the State Department in choosing option three did so in an attempt to save face internationally, rather than try to do anything that might help the situation. The State Department defended its position by saying that if they were forced to make more harsh decisions in the future, they would have less hurdles, such as domestic investment in South Africa, to contend with. ${ }^{211}$ Nixon and Kissinger probably best liked two because they felt that closer relations between the U.S. and South African governments might speed up the erosion of apartheid, thus they did

\footnotetext{
${ }^{209}$ Massie, 233.

${ }^{210}$ Coker, 19.

${ }^{211}$ Ibid, 20-21.
} 
not establish any new policies from their predecessors towards the most pressing problem of apartheid. $^{212}$

One of the major reasons for the NSC supporting option two was the investment in science and military that the U.S. already had there. NSSM-39 stated:

NASA has a space tracking facility of major importance in South Africa, and overflight and land rights for support aircraft are utilized in connection with various space shots. The NASA station is particularly oriented towards support of unmanned spacecraft and will be of key significance for planetary missions.

In addition to the "key significance" of the Johannesburg station for planetary exploration, NSSM-39 specifically addressed the importance of South Africa for the Department of Defense. NSSM-39 also noted the importance of South Africa's geographical position should there be another Suez Crisis and with the increasing concern of Soviet activity in the Indian Ocean. The importance of port and airfield access is noted, particularly in emergency situations where ships need to port. Also, the Department of Defense had a missile tracking station where some military aircraft traffic did require access to this space. However, it was noted that the station was no longer needed for research and development of missiles, as it may have once been. ${ }^{213}$

The reality was that Kissinger, Morris, and Nixon all felt that option two was best because it could help attain the objectives the U.S. set forth in NSSM-39 for South Africa. These goals included the improvement of U.S. standing in black Africa and internationally concerning race; to minimize the possible escalation of violence, which could potentially involve U.S. involvement; to minimize any opportunities the Soviets and Chinese might have to exploit the struggle between black and white in southern

\footnotetext{
${ }^{212}$ The Kissinger Study on Southern Africa, 14.

${ }^{213} \mathrm{Ibid}, 49-50$.
} 
Africa, particularly in relation to black nationalist movements that were gaining momentum with the crumbling of the colonialism; to encourage moderation of apartheid and similar policies in place in white government-led countries; and "to protect economic, scientific, and strategic interests and opportunities in the region...."214 The NSSM-39 applied each option to the list of goals and suggested pro's and con's for each. It is clear that option two was favored by its author.

The authors behind NSSM-39 were obviously big advocates of keeping NASA's access to Johannesburg's stations open, which may be why it was open until 1975. However, revelations involving the treatment of workers at the actual station would eventually come to light in 1970, thus influencing Congress to ultimately rebel against the idea of a NASA station in Johannesburg. It also probably did not hurt that the U.S. landed a man on the moon on July 20, 1969, thus successfully meeting the goal of the Apollo Missions.

\section{Diggs Commission:}

The Congressional role in policy making towards NASA in South Africa is noteworthy. In September 1970, the fatal blow was thrown at NASA by Congress. It surfaced, thanks to letters sent by a private citizen, that NASA was allowing hiring practices at the South African station to follow apartheid procedure. Lester G. Paldy, assistant professor of Physics at State University of New York, wrote to Representative Edward I. Koch of New York on July 30, 1970. In his letter, he wrote about how NASA was using federal funding to hire under the guise of apartheid policies. His letter inquired

\footnotetext{
${ }^{214} \mathrm{Ibid}, 62$.
} 
if NASA falls under the jurisdiction of the House Committee on Science and Astronautics and if it did if they would not mind looking into the matter to see if it were true.

Five days later on August 4, 1970, Koch wrote to Thomas Pain, Director of NASA, to inquire about the claim's validity. On August 19, 1970, Koch got a letter back from H. Dale Grubb, the Assistant Administrator for Legislative Affairs stating that he was looking into the issue. In that letter, Grubb stated, " NASA does not support scientific research in South Africa and the only funds expended there are for the operation and maintenance of NASA tracking stations."” In a later letter between Grubb and Koch, Grubb stated that NASA did not do any hiring at the South African stationCSIR was responsible for the hiring. By September 22, 1970, Koch was fed up with the situation and took it upon himself to write a letter to President Nixon stating that he felt that NASA was financially connected to the hiring practices of apartheid and that he wanted it stopped. On that same day, Koch wrote a letter to Grubb and said:

I believe the practices you describe in your letter of having hiring done by the 'national agency under contract to NASA for station operation' is racially discriminating and is NASA's way of evading its responsibilities. I find that an intolerable situation and urge that a change be made.

By September 28, 1970, Koch was reading these letters to Congress and demanding that something be done. ${ }^{215}$

Congressman Coles Diggs, a member of the Subcommittee on Africa of the Committee on Foreign Affairs, sought to research this issue by actually conducting a visit to the station in August 1971. Diggs was one of the first black members of Congress,

${ }^{215}$ Congressional Record, $91^{\text {st }}$ Cong., $2^{\text {nd }}$ sess., 1967, 116, pt. $25: 34021$. 
being elected to the House of Representatives in 1954 by Michigan residents. From very early on, Diggs expressed an interest in African politics, attending the independence ceremonies of Ghana in 1957. Five years into his career, he was placed on the subcommittee on Africa of the Committee on Foreign Relations. He slowly acquired legitimacy on this committee and successfully began to persuade its members to readjust their focus on southern Africa. ${ }^{216}$

Diggs would finally ascend to the chairmanship of the House subcommittee on Africa in 1969. As chairman, he was kept busy fighting U.S. policies that appeared tolerant of apartheid policies. For example, Diggs fought hard against allowing domestic flights to fly from South Africa to John F. Kennedy International Airport on South Africa Airways. He was particularly concerned with the advertisements they made in the U.S. encouraging tourists to visit its resorts, places where black U.S. citizems would not have been allowed. While the flights were never suspended, the Civil Aeronautics Board did finally pull the airline's rights to advertise in the U.S. ${ }^{217}$

Diggs also fought various other issues that symbolized implicit support of South Africa in various branches of the U.S. government. For example, he fought with the Justice Department to end the FBI's exchange of forensic information, such as fingerprints, with Vorster's police. He also openly opposed John Hurd, the Texas millionaire appointed ambassador to South Africa, because he threw a whites-only party to honor the ten-year anniversary of the founding of the Republic of South Africa.

\footnotetext{
${ }^{216}$ Massie, 264.

${ }^{217}$ Ibid, 265.
} 
Finally, he pushed to end the sale of sixty thousand tons of sugar by white farmers at twice the price of world sugar prices. ${ }^{218}$

Most notably, Diggs decided to research the claims against NASA. His findings were extensive and telling about the true nature of affairs between NASA and apartheid practices. While in South Africa, Diggs interviewed the CSIR Vice President, Dr.

Hewitt, who was the senior officer directly responsible for the NASA contract. He also interviewed the station manager D. Hogg. In the questioning, Diggs found out that the South African government purchased all of the land provided to NASA; however, operation costs were paid for by NASA. The tracking stations employed 224 whites because they had technical qualifications, whereas 61 blacks were employed in maintenance and general custodial work. Whereas the black employees were paid at most1,020 Rand per year, the lowest paid white employee earned 1,600 Rand per year. Salaries were determined by the South African Public Service Commission. ${ }^{219}$

Diggs was especially concerned about the treatment of black employees at the station, particularly because NASA did pay for operational fees. Predictably, he found that apartheid did not stop at the tracking station's gates. He found that all black employees and their families lived on site, fifteen of which lived in ten NASA-financed houses. Other black employees lived in farm labor houses that were already on the property prior to NASA and CSIR acquisition. The housing was rent free, but only the NASA housing had electricity, bathrooms, interior sewage and running water. If any of the black employees or their family members got sick, they could get a ride to the

\footnotetext{
${ }^{218}$ Ibid, 265.

${ }^{219}$ National Archives, General Records of the Department of State, RG 59, "Questions Re NASA Tracking Station: Codel Diggs Visit to Station,'Def 15 SAFR-US, 25 August 1971.
} 
hospital for fifty cents. Doctors could be called to the station, but the employees would have to pay for it. In addition, black employees were not allowed into the mess and lounge facilities in which the Diggs meetings were held. No mess or lounge was provided for them at all. Additional segregated facilities included toilets, which did not need to be marked "white" or "non-white" because "employees knew which facilities were for them."220 In September 1971, Diggs testified before Congress about his findings and said specifically about the eating conditions for black employees that, "Blacks eat outside under a tree, nibbling sandwiches." ${ }^{221}$ Hewitt defended their treatment saying that local customs could not be totally discounted just because NASA was affiliated with the station and that there should be some credit given in that appropriate housing and eating facilities were provided based on economic "rank" of the employee, regardless of race. $^{222}$ Diggs was pointing out the obvious, which was that apartheid was happening on a U.S. installation.

Hewitt and Hoggs had to do more research to answer the questions asked by Diggs. In September 1971, after Diggs visited, more truths about the station began to surface. Hewitt discovered that the 61 blacks employed represented $21 \%$ of the total staff. These employees were not allowed collective bargaining rights. The average wage for black employees was 674 Rand per year $(1$ Rand $=\$ 1.40)$. The 56 unskilled laborers earned anywhere from R. 408 to R. 780 per year. The two drivers and foreman earned R. 492 to R. 960. The three Lab Assistants earned R. 618 to R. 1020. This is clearly very

\footnotetext{
${ }^{220}$ Ibid, "Questions Re NASA Tracking Station”.

${ }^{221}$ National Archives, General Records of the Department of State, RG 59, "Diggs Committee: NASA Testimony," Def 15 SAFR-US, 30 September 1971.

${ }^{222}$ National Archives, General Records of the Department of State, RG 59, "NASA Testimony," Def 15 SAFR-US, 1 October 1971.
} 
different than what Hewitt had reported earlier in August to Diggs. White employees, in comparison, earned R. 1200 to R. 9300 . It should be noted that all of these employee costs were "directly reimbursable by NASA.",223

Higher employment opportunities for black employees, or lack thereof, were also an issue, as discovered by Hewitt. There were various training programs offered to tracking station employees. The Radio Space Research Station (RSRS) had two training programs- one for electronic technicians at the Witwatersrand Technical College and one for engineering at various local universities. No black employees were enrolled in these programs. The trainings were paid for by CSIR; however, "salaries of these trainees during 'practical experience' actual work at station during training are charged to NASA." When asked why there were no black employees enrolled in these programs, Hewitt said that no black employees had ever applied, possibly because there were no electrical engineering programs at black schools. Technically, they did not bar black employees from applying for the RSRS internships, but they did not qualify in the first place. In fact, if black employees had applied and, in theory, been accepted, CSIR would not have provided for all or even part of their tuition. This led the Pretorian Embassy to question whether or not any education was being provided to children of the black employees' family. Hewitt feigned ignorance about the educational fate of the 100 plus children on the grounds, but ultimately did admit that school was three to four miles away with no transportation provided. ${ }^{224}$

\footnotetext{
${ }^{223}$ National Archives, General Records of the Department of State, RG 59, "Diggs Subcommittee Questions Re NASA Tracking Station’Def 15 SAFR-US, September 1971.

${ }^{224}$ Ibid, "Diggs Subcommitte Questions RE NASA Tracking Station."
} 
The Diggs visit also inquired into the role of CSIR in the decision making processes. His findings stated:

Hewitt stressed that CSIR's contractual obligation was to follow sound administrative practices within context local situation and be as frugal with NASA funds as their own... Station run on reimbursement by NASA of actual cost and, as Hewitt pointed out to Diggs, SAG purchased site and provides it free of charge. There is levy for program administration overhead which totaled R. 156,580 in FY-71. This includes charge of R. 270 each for white staff and R. 70 each for African staff.

This clarification is significant for the main reason that NASA dollars, U.S. tax dollars, were paying for apartheid policy to be applied to the tracking station, thus directly tying the U.S. to South Africa in a very unattractive way. Granted, NASA tracking station personnel was not related to the military research installation that shared the site, but it was not unheard of that personnel from the tracking stations did work for military research because highly trained personnel were limited. ${ }^{225}$

A second site visit happened in October 1971 by Deputy Assistant Secretary of State for African Affairs Robert S. Smith. On November 19, 1971, Smith met with Dr. Willis Shapley, Associate Deputy Administrator of NASA Gerald Truszynski, Associate Administrator for Tracking and Data Acquisition for NASA, about the conditions of the tracking station. He recommended that ten houses built by NASA needed to be repaired and that more family houses needed to be built since most of the employees lived in 100year old farm houses that lacked water and electricity. A school bus needed to be provided to kids whose school was more than four miles away. A nurse and clinic needed to be located on site and that medical care provided off site should have

\footnotetext{
${ }^{225}$ National Archives, General Records of the Department of State, RG 59, "Diggs Subcommittee Questions RE NASA Tracking Station,’Def 15 SAFR-US, September 1971.
} 
transportation costs paid for. An indoor eating facility also needed to be built for the staff and that they should get fed lunch as well. The wage scale had "room for improvements." Also, the CSIR needed to make more serious efforts to recruit nonwhites for technical positions. If this could not be done in South Africa, then maybe NASA could offer training in the U.S. for non-whites so they could apply for and be accepted to more technical positions. At the meeting, Shapley said that he felt improvements could happen without the special request or additional funds from Congress. $^{226}$

Shapley and Truzynski traveled to South Africa themselves on December 1, 1971. The U.S. government was very wary of the South African government and CSIR seeing this visit as an attempt to get CSIR to change as quickly as possible, rather that they should move at a pace as they saw fit to make equitable changes that would fix the human rights violations concerns. ${ }^{227}$ NASA did face an uphill battle, as Hewitt very clearly stated to NASA in a previous conversation that while improving housing and eating facilities was one thing and possibly doable, improving opportunities for nonwhite employees was far less feasible. "He emphasized a strong belief that any precipitous effort in this area would impact present staff would severely jeopardize CSIR ability to maintain current high level of operating efficiency." 228 These thoughts would ultimately be repeated to Shapely and Truzynski when they visited on December 1.

\footnotetext{
${ }^{226}$ National Archives, General Records of the Department of State, RG 59, "Conversation with NASA Officials Concerning Deep Space Tracking Station in South Africa- November 19, 1971,'Def 15 SAFRUS, 22 November 1971.

${ }^{227}$ National Archives, General Records of the Department of State, RG 59, "Shapely Visit to South Africa," Def 15 SAFR-US, 24 November 1971.

${ }^{228}$ National Archives, General Records of the Department of State, RG 59, "NASA Discussions with Dr. Frank Hewitt of CSIR,” Def 15 SAFR-US, 24 November 1971.
} 
The issue inevitably made its way back to Congress in the form of NASA's budget approval. Using one of its tools to control foreign policy via its Constitutional rights, Congress debated extensively what to do about funding in relation to the Johannesburg's recent findings about their enforcement of apartheid on its employees as revealed in the Diggs visit. Representative Charles Rangel (D-NY) was a relatively new black Congressman from Harlem when he introduced a restrictive amendment to the bill about NASA's budget. Concerning the budget, NASA would not be permitted to use any of the budget "in the Republic of South Africa." Rangel's rationale for this was:

The continued operation of our NASA tracking station in Johannesburg, South Africa, however, compromises American integrity and completely undermines our stated goals of equal opportunity and equal justice.

For Rangel, funneling tax payer dollars to CSIR and its use of apartheid was unacceptable, particularly because of their separated facilities, such as restrooms and dining halls, and dual pay scales that were incomparable. In addition, he was very concerned that of the 243 visits made by U.S. personnel on behalf of NASA, there were no black Americans sent, possibly to honor the 1965 Independence decision set forth by the South African government. ${ }^{229}$

There were Representatives that agreed with him. Representative Ed Koch (DNY) pointed out the double standard employed by this situation:

What, for instance, would be the response of this country if the Northern Irish Government said to the United States, 'You have a facility here but you may not employ Catholics, or if you do, you will them at less than what you pay the Protestants.' We would say, 'This is an outrage, we cannot do that...' Or take the situation when not so long ago certain Arab states said, 'You may not have a Jewish soldier in this facility.' ... And so, today the black community rightfully

${ }^{229}$ Congressional Record, $92^{\text {nd }}$ Cong., $2^{\text {nd }}$ sess., 1972, 118, pt. 11: 13642. 
asks how we can sit here and permit Government moneys to be appropriated and used in a discriminatory way...?

Representative Ron Dellums (D-CA) agreed with Koch and Rangel saying that his frustration was with the fact that the U.S. had no problem keeping open the station to protect a handful of astronauts but did so at the risk of the dehumanization of the dozens of black employees at the station. Representatives who agreed with the amendment had no difficulty basing their decision on the clear human rights violations committed by CSIR and NASA (albeit indirectly). ${ }^{230}$

This amendment tipped off a Congressional debate. There were Congressmen that disagreed with the amendment for a variety of reasons. Texas Representative Olin Teague opposed the amendment because of the tactical concerns, saying that it was unreasonable to leave a gap in a major tracking zone for the space program and then ultimately revise the use of South Africa to help track ships and planes in the area as well. Another common argument from several Representatives was that if the U.S. were to only cooperate with countries that subscribed to U.S. ways of life that "we are going to become a mighty lonesome country." In addition, it was pointed out that not doing business with the South African government and CSIR would be more detrimental to U.S. programs than to South Africa's programs and that U.S. interests should be put first. Robert Leggett (D-CA) said:

...I do not believe we should use the space program as a vehicle to vindicate civil rights theories or to use civil rights as a basis to kill the space programs... We need this space station there to make the space program go. I do not believe anybody should be misled that this is a civil rights vote in any way, shape, or form. It is a clear effort to kill the space program. ${ }^{231}$

\footnotetext{
${ }^{230}$ Ibid, 13643.

${ }^{231}$ Ibid, 13643-13644.
} 
Many of the Representatives who spoke out against the amendment would preface their comments with the context that this was not a race issue, but a national security or scientific advancement issue. Ultimately, the nays would rule the day, as the amendment was rejected prior to be sent on for authorization.

In May 1973, a House bill that would have cut \$3 million of NASA funding for stations in South Africa was defeated, but the fate of this station was becoming clear. When the bill was up for debate, NASA tried to argue that it was helping improve local conditions for black employees by providing approximately $\$ 109,000$ a year on improvement for programs for the black community, including constructing an elementary school, better housing, and a small onsite medical facility onsite for black employees and family members to use. However, this could not overcome the fact that even though black employees consisted of $25 \%$ of the total employees at the station, they only earned $5 \%$ of the total wages paid to employees. In the official historical account of the tracking stations, NASA historian Sunny Tsiao said that "black and liberal politicians" were to blame for the demise of the station. There is a tinge of blame in Tsiao's account as he stated:

The Republic of South Africa, being on the very southern tip of the continent, was ideal. As unfavorable as the South African political climate was, it was actually the most democratic and most stable government accessible to the United States on the continent at the time. 
The question is immediately raised is "Democratic for who?" On July 10, 1973, NASA Administrator James C. Fletcher announced that NASA was pulling out of South Africa completely by $1975 .^{232}$

Throughout the various issues with NASA and access to their satellite tracking stations, the undertones of the space race segment of the global Cold War are clear. The space race in and of itself was endemic of the global Cold War; however, there was little concern to the retention of the satellite stations due to the threats by the Soviet expansionism in South Africa proper. The issue of the tracking stations uniquely crosses U.S. civil rights issues with those of South Africa's apartheid. The pressure of the global Cold War further aggravated the situation because policy employed in this situation could have potentially impacted decisions in other areas, such as the naval ports.

NASA and the Department of Defense satellite and missile tracking stations was another reason the U.S. wanted to maintain friendly relations with the South African government. Had they decided to relocate all their ships to Kenya, for example, they would risk losing access to the vital tracking stations in Johannesburg. For the U.S. it was far more beneficial to maintain the status quo with South Africa then risk losing access to their strategic location, particularly in light of the space race that had preoccupied the scientific community. However, this situation is unique in and of itself because it is a clear example of the U.S. allowing apartheid to be used to support its own efforts in the space race.

${ }^{232}$ Tsiao 208-211. 
The Diggs Commission's directly conveyed the connection of South Africa's importance to the U.S. despite the close connection of U.S. policy and apartheid. He proved that U.S. government dollars were supporting apartheid directly. The U.S. paid for a significant amount of the tab accrued by the NASA- CSIR satellite tracking station in Johannesburg. That money paid for property, maintenance, and staffing in Johannesburg. At the station, they heavily employed apartheid policy when hiring, paying, and housing the black African staff. Despite his findings, Congress was split. Some members found it abhorrent that the U.S. would knowingly support apartheid to this extent. However, other members felt it was irrelevant as the stations were helping to advance the U.S. in the space race. There was complete disregard for apartheid in exchange for benefitting the U.S. scientifically and militarily.

All branches of the U.S. government knew that supporting the satellite and missile tracking stations was controversial. In NSAM No. 295 of April 1964, it was declared that the stations should be kept secret as they did not want a negative backlash to come from the public. It also asked NASA and the Department of Defense to be prepared to move their tracking stations at a moment's notice for fear of the South African government pulling the plug on the project or the public finding out and needing to move so as to not be seen as being supportive of apartheid through disregard of South Africa's policies.

The controversy surrounding the tracking stations is a clear example of the U.S. government making decisions based on the global Cold War, more specifically the space race component of the global Cold War. They were involved in the space race, which saw a restructuring of NASA and the educational system. South Africa's stations were certainly involved in this. However, holding onto the stations was intertwined with 
access to naval and air fields. It was more complicated than just wanting to maintain the bases for the sake of beating the Soviets in the space race. The Johannesburg station was crucial in landing a man on the moon, and therefore policy decisions reflect the need to win the space race. 


\section{Chapter Four: Weapons Sales to South Africa}

South Africa has a significant amount of natural wealth that was exploited from

the 1860 s on. The result was to provide enough extra cash to build a strong military infrastructure. During the 1960s, the South African government wanted to buy weapons, artillery, and vehicles. Despite having the cash and the ability to carry, they did have a difficult time maneuvering around the various embargoes that were placed on them by the UN and the U.S. Executive branch. Regardless, they still obtained weapons even after the heavy international criticism that followed the Sharpeville Massacre. The sale of weapons on behalf of the U.S. and international community is an important indicator of the relationship South Africa had with the U.S., which was one of productivity. While weapons sales were not nearly as important to the U.S. to maintain as, say, port and air field usage, a positive relationship was important and the sale of weapons could smooth any ruffled political feathers fairly quickly.

Much of South Africa's productivity was built off the backs of those inflicted by apartheid. The non-white population was vital to the efforts of industrialization. To keep the non-white population in check, numerous laws involving Bantustans, pass laws, education prohibition, and censorship, among others, were passed to keep the population encased in what could be compared to indentured servitude. The South African Executive branch saw to it that they had the weapons necessary to keep this population in line with their rules and goals. In 1960-1961, the estimated military budget for the South African government was \$44 million Rand. In 1965-1966, it was \$230 million Rand. In 1970-1971 it was $\$ 257.1$ million Rand. By 1975-1976, when the economic boom would begin to fizzle, the South African government had a military budget of $\$ 948$ million 
Rand. ${ }^{233}$ While it can be argued that South Africa felt the need for security as its European colonized neighbors were gaining independence rapidly throughout the second half of the twentieth century, it is difficulty to not see the parallels between the passing of decrees and laws during this time and the need for enforcement on the home front. From 1967-1971, pass laws were being stringently enforced. A result was that three million people were arrested during this time period for pass violations. This is equivalent to $25 \%$ of the population of Africans in South Africa. On average, the police were arresting 1,649 people daily. ${ }^{234}$

This chapter will look at the embargoes set forth by the U.S. government and the UN and how they were broken repeatedly in the 1960s and 1970s. There was a connection between weapons sales and the desire to have good relations with the South African government. While some historians, such as Anna-mart van Wyk, claim that the weapons sales were to keep the South Africa government in the U.S.'s good graces because they were an important ally against the communist threat, they were actually used to keep access to ports and NASA space stations in an effort to stay ahead of the Soviets in the global Cold War. ${ }^{235}$ South Africa was too good an ally geographically and economically to throw away over the sale of weapons that could potentially be used in the war for apartheid.

\section{Historical Context to Economic Importance of South Africa:}

\footnotetext{
${ }^{233}$ Abdul S. Minty, "South Africa's Military Build-up: The Region at War," in Frontline Southern Africa: Destructive Engagement, ed. Phyllis Johnson and David Martin (New York: Four Walls Eight Windows, 1988), 238.

${ }^{234}$ Massie, 224.

${ }^{235}$ Anna-Mart van Wyk, "The USA and apartheid South Africa's nuclear aspirations, 1949-1980," in Cold War in Southern Africa: White power, black liberation, ed. Sue Onslow (New York: Routledge, 2009), 56.
} 
South Africa became economically important for Europeans as early as 1652 when the Dutch East India Company (VOC) established a base at the Cape of Good Hope. The ships traveling through the Cape of Good Hope were traveling to East Asia for the VOC. With the establishment of this base came a large influx of Europeans who sought to provide food, supplies, and soldiers to help support the VOC. Permanent establishments housed Europeans whose task was to grow wheat and vegetables and to breed cattle and sheep. ${ }^{236}$ Though the VOC did not have the intention to acquire a large colony to support the fort at Table Bay, it did provide a basis for later colonial conquest of South Africa. The farms that were to be temporary support for the VOC became permanent and more expansive. $^{237}$

Throughout the seventeenth and eighteenth centuries, the European population steadily grew. There were many causes for the influx of Europeans, including French Protestants fleeing persecution in 1685. Other Europeans fled confinement, regulation, taxes, and various types of persecution in Europe. Also Dutch and German sailors and soldiers working for the VOC began to move to South Africa permanently. ${ }^{238}$ By 1806 , when the British took control of the colony, there were 27,000 Europeans permanently residing in South Africa. ${ }^{239}$

During the nineteenth century, under British rule, farming grew exponentially in South Africa. As opposed to the Dutch, the British encouraged permanent settlement by Europeans because they wanted the colony to become self-sufficient in its costs to the

\footnotetext{
${ }^{236}$ Feinstein, 1.

${ }^{237}$ Nigel Worden, The Making of Modern South Africa: Conquest, Segregation and Apartheid (Cambridge: Blackwell, 1994), 9.

${ }^{238}$ Berger, 28.

${ }^{239}$ Charles H. Feinstein, An Economic History of South Africa: Conquest, Discrimination and Development (New York: Cambridge University Press, 2005), 2.
} 
British Empire. From wineries to wool, the British began to expand on the production of goods for export to Europe in South Africa. For example, merino wool was exported at a quantity of 20,000 lbs in 1822 to Europe. By 1862 , it had climbed to $26,000,000 \mathrm{lbs}^{240}$

British territorial expansion was slow and methodical during the nineteenth century. This was not without conflict from the African kingdoms that resided in the annexed areas and the Boers, descendants of the Dutch who moved inland to farm. While, in most cases, the various African kingdoms were easily defeated, the Boers proved to be more of a challenge. The Anglo-Boer War of 1899-1902 marked the completion of the process of annexing the whole of South Africa for the British. The war was very destructive to property and life, with 22,000 British troops, 26,000 Boer women and children, and 14,000 African internees being killed. Over 30,000 farmsteads were destroyed as well. ${ }^{241}$ While this war did result in British annexation of South Africa, it did not have a clear political outcome for the Boers. Boers were allowed to govern themselves under the British and they were allowed to keep much of their land, with encouragement from the British to continue farming and developing the South African countryside. $^{242}$

In the late nineteenth and early twentieth century, South Africa experienced a mineral revolution that would build up their economy for decades to come and encourage foreign investment. Diamonds were initially discovered in 1867 in the north-eastern Cape. By 1880, the De Beers Consolidation Mines, under the control of Cecil Rhodes, had monopolized the industry by buying up land with known and potential diamond

\footnotetext{
${ }^{240}$ Ibid, 28.

${ }^{241}$ Worden, 29.

${ }^{242}$ Ibid, 31-32.
} 
shafts in it. ${ }^{243}$ The mining of diamonds rapidly increased upon the discovery of diamond shafts. In 1872, output of diamonds surpassed 1,000,000 carats. By 1888, output of diamonds totaled over 3,500,000 carats. Also, in 1884, major deposits of gold were discovered in the Transvaal in unique reef-like formations. By 1910, exports of gold equaled $£ 27,000,000 .^{244}$

When the Depression hit, South Africa's exports dropped by $25 \%$. This included diamond sales, which nearly collapsed during the early 1930s. However, in 1933, the value of gold skyrocketed. ${ }^{245}$ In 1930 , gold was worth $£ 4$ per ounce and by 1970 it was worth $£ 13$ per ounce. ${ }^{246}$ By the late 1930 s, South Africa was exporting an annual average of $£ 80,000,000$ of gold per year. Although gold and diamond mining was not the sole cause, it did significantly contribute to the growth of South Africa's GDP by $67 \%$ between 1933-1939. ${ }^{247}$

The success of the gold market encouraged the South African government to industrialize. Industries producing machinery, electrical equipment, explosives, wire cable, cement, and footwear all began to experience major growth. It also stimulated coal mining and the generation of electricity to provide for the growing need of energy. Transportation, namely railroads, was also expanded. Because of this explosion, South Africa saw the need for doctors, lawyers, geologists, accountants, bankers, engineers, and educators grow. ${ }^{248}$

\footnotetext{
${ }^{243}$ Feinstein, 93.

${ }^{244}$ Ibid, 99-100.

${ }^{245}$ Richard W. Hull, American Enterprise in South Africa: Historical Dimensions of Engagement and Disengagement (New York: New York University Press, 1990), 177.

${ }^{246}$ Feinstein, 96.

${ }^{247}$ Hull, 180.

${ }^{248}$ Feinstein, 107-108.
} 
During WWII, the U.S. private sector began to invest in South Africa. By 1943, South Africa saw U.S.-owned assets reach \$86.6 million, including \$50.7 million in direct investments. Johnson and Johnson, Colgate-Palmolive, and Coca-Cola all found markets in South Africa. Also, South African became the seventh largest market for U.S. auto parts and accessories. ${ }^{249}$ In 1958, Charles Engelhard, a U.S. citizen who ran a network of companies with enormous holdings in chromium, coal, gold, and uranium, arranged for a $\$ 30$ million U.S. bank loan to the South African government, which helped keep South African government and industry afloat right after the Sharpeville Massacre in $1960 .^{250}$ Chromium and uranium were both significant to the U.S. in the context of the global Cold War because they could be used to make better weapons, weapons delivery systems, and vehicles, such as tanks. For example, chromium is used to harden steel and can be used in missiles and tanks alike to make a stronger machine. Between 1966-1970, the South African economy was still flourishing at a growth rate of $7 \% .^{251}$

\section{Weapons Sales under Kennedy:}

President Kennedy attempted to put pressure on the South African government, particularly after the Sharpeville Massacre, but he was up against domestic, international, and bureaucratic backlash should he do so. The Defense Department valued over flight rights, the use of South African ports, both naval and air, and information on Soviet ship movement in the Indian Ocean. The Commerce Department wanted to continue spending

\footnotetext{
${ }^{249}$ Hull, 182.

${ }^{250}$ Robert Kinlock Massie, Loosing the Bonds: The United States and South Africa in the Apartheid Years (New York: Doubleday, 1997), 214-215.

${ }^{251}$ Ibid, 221.
} 
and investing in the region as South Africa was a viable market. The Treasury

Department was worried about the potential destabilizing effect that the disruption of the gold flow could have on the international monetary system. And, finally, the CIA wanted to protect its close relationships to its South African contacts. ${ }^{252}$

Between 1958-1970, South Africa’s defense budget multiplied seven-fold to $\$ 350$ million in 1970s dollars. The army possessed 200 tanks, the navy had 30 warships and three submarines, and the air force had 44 British jets, 50 French Mirage fighter-bombers, 80 helicopters, and over 100 other types of military aircraft. They developed and built sophisticated underground radio communication centers, underground air defense radar stations, and five "anti-terrorist" training centers. ${ }^{253}$ Despite having a lucrative export business of minerals, South Africa could not build up the largest military in the region without some outside help. The United States, France, and England were all responsible for helping to build up their military, despite numerous embargoes and the risk of bad publicity should their aid be found out.

A subsequent question that follows the statistics presented on the growth of the South African military would naturally be "why." While South Africa found itself at war in the 1970s with Angola, it was largely concerned with upholding apartheid, particularly as their cushion of apartheid-friendly neighbors began to dissipate. South Africa felt that it was necessary to uphold a "total strategy" policy that involved the mobilization of all forces- diplomatic, economic, political, and military- in defense of apartheid. This not only included total control of its people internally, but striking absolute fear in its

\footnotetext{
${ }^{252}$ Massie, 213.

${ }^{253} \mathrm{Ibid}, 245$.
} 
neighbors should they consider aiding anti-apartheid groups. South Africa also liked being the heart of the transportation and communications systems and did not want neighboring countries to replace them; thus, South Africa aggressively pursued its total strategy in its neighboring countries in a series of undeclared wars, namely South West Africa. $^{254}$

The development of the NASA base in South Africa was not just for assistance to NASA flights, but it also housed a missile tracking station. In a letter to Under Secretary of State Chet Bowles from Deputy Secretary of Defense Roswell L. Gilpatric dated March 16, 1961, Gilpatric wanted to know how essential it was to have a station in South Africa. He stated:

Many months ago it became clear that the full development of our national missile and space vehicle capability would require the geographical extension of our Atlantic Missile Range facilities into the general area of southeastern Africa. Such facilities are required for the testing of missiles at ranges over 5000 miles....

Furthermore, he said that a ship-based station could not remotely satisfy the need for local airfield support to promote the long-range missile tests. With the State Department, NASA, and South African government already on board and okay to create the longrange missile testing site, it seemed futile to avoid using the NASA base also as a base to do long-range missile testing. ${ }^{255}$ In further correspondence, Bowles did mention concern for the racial policies, as Sharpeville was still fresh in the minds of the U.S. government when dealing with South Africa. Gilpatric addressed those concerns in a letter dated May

\footnotetext{
${ }^{254}$ Phyills Johnson and David Martin, Frontline Southern Africa: Destructive Engagement (New York: Four Walls Eight Windows, 1988), xxii.

${ }^{255}$ Letter from the Deputy Secretary of Defense (Gilpatric) to the Under Secretary of State (Bowles), 16 March 1961, FRUS 1961-1963, XXI: 588-589.
} 
17,1961 , saying that the support provided at this base for the long-range ballistic missile tests were of "recognized importance to national security."256

Upon hearing about the agreement made between the U.S. and South Africa,

Adlai Stevenson, then the Representative to the U.N., wrote a letter to Secretary of State

Dean Rusk on June 2, 1961 stating:

While I am not fully informed about the necessity for this transaction, I am sufficiently concerned to presume to send you this note of caution. At a time when the feeling about apartheid and the policy of the Union of South Africa is rising everywhere, including pressure for sanctions in the U.N., I would think that the necessity must be very compelling to risk the repercussions from a transaction of this kind if and when it becomes known, as it must be inevitably. I hardly need add that relations with the rest of Africa, and especially the new states, are important to our security too. ${ }^{257}$

Stevenson knew how bad public and foreign relations the U.S. could get by tying themselves so pivotally to South Africa. To Stevenson, it was an unnecessary and fairly risky new move in the light of relationships with the newly emerging African states.

It would not be long before the access to the missile and satellite tracking stations would become connected to the sale of weapons. On June 30, 1961, the State Department informed the Department of Defense that there was a deal on the table for large aircraft to be sold from Lockheed to the South African government. The U.S. State Department initially could not authorize the sale, but would delay giving Lockheed the final decision until the negotiations for a two-year contract allowing access to the missile and satellite tracking stations was complete. ${ }^{258}$

\footnotetext{
${ }^{256}$ Letter from the Deputy Secretary of Defense (Gilpatric) to the Under Secretary of State (Bowles), 17 May, 1961, FRUS 1961-1963, XXI: 591.

${ }^{257}$ Letter from the Representative to the United Nations (Stevenson) to Secretary of State Rusk, 2 June 1961. FRUS 1961-1963, XXI: 594.

${ }^{258}$ Letter from the Under Secretary of State (Bowles) to Deputy Secretary of Defense (Gilpatric), 30 June 1961, FRUS 1961-1963, XXI: 597-598.
} 
A few months later in September 1961, it became clear that there was a growing connection between weapons sales and access to the tracking stations. The South African Embassy sought formal approval from the U.S. to buy seven C-130s from Lockheed:

It is Ambassador Satterthwaite's view that refusal of the sale may foreclose any further South African cooperation in the field of mutual defense and make it impossible to negotiate arrangements for the continued use of the tracking facilities. $^{259}$

The U.S. found itself in a tight spot because they wanted to make good on an intended practice of quid pro quo where they got access to the tracking stations in exchange for weapons, but they were fearful of the potential backlash they would receive from the domestic and international community should they approve the $\$ 100$ million sale of airplanes. To bout, should the U.S. have denied them the sale, South Africa would have still gotten the planes from France, thus upsetting the potential access to the tracking sites and an American corporation. ${ }^{260}$ The sale would ultimately be approved on September $29,1961 .^{261}$

\section{French Interests in Africa:}

France had a vested interest in Africa and would prove to be a potential competitor for arms sales to South Africa with the U.S. government. Along with Britain, France also had an African empire, with the bulk of their colonies located in northern and western Africa. The nationalization of the Suez Canal in 1956 had implications for the

\footnotetext{
${ }^{259}$ Memorandum From the Deputy Assistant Secretary of Defense for International Security Affairs (Williams) to the Deputy Secretary of Defense (Gilpatric), 16 September 1961, FRUS 1961-1963, XXI: 602.

${ }^{260}$ Letter from the Under Secretary of State (Bowles) to the President's Special Assistant for National Security Affairs (Bundy), 21 September 1961, FRUS 1961-1963, XXI: 603-604.

${ }^{261}$ Telegram From the Department of State to the Embassy in South Africa, 29 September 1961, FRUS 1961-1963, XXI: 607.
} 
French government that moved past the Middle East and into northern and western Africa. In its failure to capture the Suez Canal and remove Nasser from power, the French government soon saw a renewed vigor in its African colonies to gain independence. The leadership of the independence movements in the colonies saw the Anglo-French fiasco of Suez as a sign of the collapse of the colonial system throughout the world, including Africa. ${ }^{262}$

As Charles de Gaulle assumed power as president of France in 1958, he faced an African constituency that demanded freedom from its colonizers. The French government had already granted Tunisia and Morocco independence in 1956. However, Algeria, home to over one million French, would be different. Between 1956-1958, a brutal war was waged between the Algerians and the French. This war would ultimately come to an end under de Gaulle. In September 1959, de Gaulle stated publicly that Algerians had a right to determine their own future. At the Evian Conference in France in May 1961, negotiations began between the two governments to usher in independence through a referendum to be held on July 1, 1962. Over 6 million Algerians voted for independence and thus earned it on July $3,1962 .{ }^{263}$

With independence in the other French West and Equatorial African colonies in the late 1950 s and early 1960 s, came the need to establish a continued French military presence to support newborn local security forces, to assure stability in the region, and to protect French citizens and their interests in the newly independent states. De Gaulle

\footnotetext{
${ }^{262}$ Jean Lacouture, De Gaulle: The Ruler, 1945-1970 (New York: WW Norton \&Company, 1991), 198199.

${ }^{263}$ David D. Newsom, The Imperial Mantle: The United States, Decolonization, and the Third World (Bloomington: Indiana University Press, 2001), 83.
} 
realized that having a full-blown French military in the former colonies would be politically undesirable and very expensive, thus he sought to provide local forces with the resources and training they would need to uphold the goals of having a military presence in the former French colonies. ${ }^{264}$ In essence, de Gaulle's military strategy was that of "out of sight, but not out of mind":

President de Gaulle saw clearly... that the large colonial army could best be used as the nucleus for the formation of national armies. Although a continued French military presence in the newly independent countries might be desirable from a French point of view, it should be discreetly limited in size and restricted to a few carefully chosen bases and logistics facilities. To combine effective deterrence with political sensitivity, the French sword must be out of sight, but not out of mind. $^{265}$

To sustain this policy, de Gaulle's government had to assure access to weapons and training to the former French colonies.

The French government expanded its military assistance through formal agreements to other former non-French colonies including the Congo, Burundi, Rwanda, the Ivory Coast, Gabon, Senegal, and Cameroon, among others. The rationale behind the expansion was to protect economic interests, often in the form of raw materials, and to protect French residents. ${ }^{266}$ Although the French did not have a formal agreement with South Africa, they justified the selling of weapons to South Africa as being a contribution to the safety of South Africa from external threats. ${ }^{267}$ Thus, the French became major sellers of weapons to the South African government throughout the 1960s and 1970s and

\footnotetext{
${ }^{264}$ Francis Terry McNamara, France in Black Africa (Washington DC: National Defense University Press, 1989), 146.

${ }^{265}$ Ibid, 156.

${ }^{266}$ Ibid, 149.

${ }^{267}$ Edward A. Kolodziej, “France and the Arms Trade,” International Affairs 56, no. 1 (Jan. 1980): 60.
} 
would become a constant competitor to the U.S. Executive branch, which sought to sell weapons to South Africa to help maintain positive relations with them.

Africa would not be the only location where de Gaulle, Kennedy, and Johnson would have conflicting interests. In addition to the challenge of weapons sales, de Gaulle also sought to improve relations with Latin America. After becoming President, de Gaulle traveled to Latin America in early 1961 to strengthen diplomatic ties. ${ }^{268}$ Relations between Kennedy (and later carrying over into Johnson's presidency) and de Gaulle became more complicate when de Gaulle opposed a joint plan for coordinated defense of the Atlantic. Why he rejected a joint plan for defense of the Atlantic is unclear, but it was most likely part of de Gaulle's goal to establish French policy in Latin America as he saw fit, rather than fitting his foreign policy goals into that of what the U.S. White House had already established. $^{269}$

\section{Kennedy's Embargo Challenged:}

In 1963, the South African government asked for submarines; however, this request was tangled up in the embargo the U.S. imposed on South Africa in August 1963. In a speech given by Stevenson to the UN on August 2, 1963, the U.S. announced its official position to stop selling weapons to South Africa:

...the United States has adopted and is enforcing the policy of forbidding the sale to the South African Government of arms and military equipment, whether from government or commercial sources, which could be used by that government to enforce apartheid....

\footnotetext{
268 "French-Latin Ties Seen as Aiding U.S.," New York Times, 23 February 1961, pg. 9.

269 James Reston, "Washington," New York Times, 10 January 1964, pg. 42.
} 
There was, of course, a stipulation to the embargo of weapons, namely that existing contracts would be honored and that weapons used for "defense against external threats, such as air-to-air missiles and torpedoes for submarines" must be honored. ${ }^{270}$ These segments of Stevenson's speech eventually gave the U.S. enough wiggle room to justify the sale of several different types of weapons, including small arms and planes.

The immediate aftermath of the speech created much speculation among the South African government and invigorated UN members. While various African countries cheered the action by the U.S., it was speculated that the South African government would seek retaliation. The New York Times stated that, "Much American investment could suffer and United States Government agencies in the country, such as missile-tracking stations, could find their facilities withdrawn."271 Regardless, the UN, possibly inspired by Stevenson's speech, followed suit and banned arms shipments, ammunition, and military vehicles to South Africa in a 9-0 vote on August 7, 1963. The original draft of the resolution called for a boycott of all South African goods to refrain from exporting materials of military value; however that was removed from the resolution. $^{272}$

The U.S. immediately had to deal with several situations challenging the embargo, the first of which was the sale of four 1700 ton attack submarines that the South African Naval Chief of Staff "urgently" requested on March 16, 1963, five months before the embargo was set into motion. Each submarine would have cost $\$ 40$ million. At the time, U.S. policy was to sell military equipment for external defense only, which made

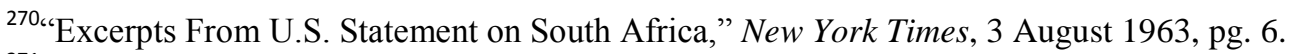

${ }^{271 ، " U . S . ~ S t a n d ~ o n ~ A r m s ~ S t i r s ~ S o u t h ~ A f r i c a, " ~ N e w ~ Y o r k ~ T i m e s, ~} 5$ August 1963, pg. 2.

272 "U.N. Adopts Curb on South Africa," New York Times, 8 August 1963, pg. 1.
} 
the U.S. Executive branch look at this request closely. Rusk told President Kennedy that a "yes" to the sale would be very beneficial for good military relations, help keep tracking stations open, and provide an alternative for the Suez should there be a crisis there again. He did not say why a "no" would be beneficial, as he feared that relations with the South African government were deteriorating and saying no to the sale might have been a serious casualty for them. He asked Kennedy for guidance, but it is clear that he was hoping for approval on the sales. ${ }^{273}$

Rusk elaborated further on why he thought the U.S. should sell the submarines to South Africa. He felt that by selling South Africa weapons, the U.S. would maintain a hand in helping to influence and promote human rights and democratic ideals. This would echo that later established NSSM-39. In addition, he said, "But I believe it is worth reminding ourselves that there are other states where obnoxious practices of one sort or another exist.” He listed countries such as Korea, Poland, Saudi Arabia, Spain, and Turkey to make his point. Furthermore, he said:

I will admit that apartheid presents a case of unusual difficulty but I would not put it ahead of the violations of human rights within the communist bloc or in the certain countries governed on authoritarian basis with which we have correct and sometimes even friendly relations. ${ }^{274}$

Rusk clearly felt it was a good idea to sell the submarines, and possibly other weapons, as the U.S. had in the past looked the other way when there were clear violations happening in the name of maintaining precious allies, particularly in regions of value, such as the Middle East, Southeast Asia, and Eastern Europe.

\footnotetext{
${ }^{273}$ Memorandum from Secretary of State Rusk to President Kennedy, 16 March 1963, FRUS 1961-1963, XXI: $627-628$.

${ }^{274}$ Memorandum From Secretary of State Rusk to the Under Secretary of State for Political Affairs (Harriman), 15 June 1963, FRUS 1961-1963, XXI: 634-635.
} 
Although he was not specifically commenting on the sale of submarines to South Africa, on July 11, 1963, McNamara weighed on the weapons sales debate in a letter to Rusk. He was a moderate in the debate, seeing both advantages and disadvantages on selling weapons. On the one hand, he knew the importance of maintaining good relationships with South Africa, particularly in light of U.S. military and NASA access to the Atlantic Missile Range tracking station, saying, "this station has contributed greatly to our missile development and other space programs and will continue to be important after 1963, although not vital." However, he felt it necessary to take into consideration upsetting the "African bloc." McNamara felt it was essential to maintain positive relationships with other sub-Saharan African nations should the U.S. lose access to South African ports and airfields. In short, McNamara stated, "Given these considerations, it should be our basic objective, to the extent that it is possible, to avoid prejudicing our relationship with either side in this dispute." He was hoping that there would not even be a vote in the UN to have serious economic sanctions and an arms embargo against South Africa. $^{275}$

Ultimately, McNamara would lean towards Rusk's side in advocating for the sale of the submarines to South Africa. Rusk and McNamara made a strong case to sell submarines to South Africa. Their first point referenced a statement South African Foreign Minister Louw said on September 10, in which the U.S. and Britain could not count on continued support against communism and that the Simonstown Agreement on use of naval facilities might be dissolved in the wake of statements the British and U.S.

\footnotetext{
275“'Secretary Robert McNamara, Letter to Secretary Dean Rusk, July 11, 1963," South Africa and the United States: The Declassified History, ed. Kenneth Mokoena (New York: The New Press, 1993),62-63.
} 
made at the UN and in other venues about apartheid. Their second point focused on how U.S. companies that produced ships stood to make \$75-90 million for the sale of the submarines, thus benefitting the U.S. balance of payments. The third and final point specifically stated how the U.S.

must remember that the South Africans agreed to establish the missile and satellite tracking facilities because of an exchange of Aide Memoires on June 15, 1962, which noted that the U.S. was willing give "prompt and sympathetic attention to reasonable requests for the purchase of military equipment required for the defense against external aggression., 276

This illustrates the connection between access to facilities to the sale of weapons to South Africa.

Kennedy responded more cautiously to the sale of submarines. By the time of his assassination, the South African navy had modified their request to smaller submarines totaling a value of $\$ 38$ million. They also wanted a $\$ 35-40$ million air defense system for the Simonstown Naval Base. ${ }^{277}$ On September 23, 1963 it was made clear that Kennedy wished to table the sale of the submarines:

The U.S. can make no decision before the end of this year regarding the sales and any eventual decision will be taken in the light of the circumstances at the time the questions considered, under our policy stated in the UN Security Council in August. $^{278}$

This issue would not be resolved until Johnson's administration due to Kennedy's assassination.

\footnotetext{
276،Secretary Dean Rusk and Secretary Robert McNamara, Memorandum for President John Kennedy, September 16, 1963," Ibid, 62-67.

${ }^{277}$ Memorandum From William H. Brubeck of the National Security Council Staff to President Kennedy, 19 November 1963, FRUS 1961-1963, XXI: 658.

${ }^{278}$ Memorandum From the President's Sepcial Assistant for National Security Affaris (Bundy) to Secretary of State Rusk, 23 September 1963, FRUS 1961-1963, XXI: 649.
} 
Even though the sale of the submarines was continually getting tabled, various personnel- diplomatic and military- weighed in on the issue. In November 1963, a team was sent to South Africa to discuss the sale of the submarines. The team ultimately recommended that they do sell the South African government three conventional submarines. ${ }^{279}$ It is unclear specifically who was on the team, but various members of the Defense Department were involved. On April 13, 1964 Chairman Joint Chiefs of Staff Maxwell D. Taylor highly recommended to Secretary of Defense McNamara that the sale of the submarines should be completed. He believed that not selling the weapons would compromise U.S. military interests in the country, of which there were many, namely the Atlantic Missile Range tracking station. He felt that there was a resentment growing among the South African government and military towards the U.S. and the quick, decisive sale of the submarines would help smooth this over. ${ }^{280}$ Ultimately, the sale of the submarines would be fatally postponed upon the release of NSAM No. 295 in April $1964 .^{281}$

A New York Times article from October 10, 1963 praised the U.S. government for following through on the arms embargo, regardless of debating the idea to sell submarines to the South African navy. Despite filling remaining contracts to sell them $\$ 3$ million of air-to-air missiles, submarine torpedoes, and spare parts for seven C-130 transport planes, the U.S. was seen as holding up the embargo. ${ }^{282}$ There is no mention of

\footnotetext{
${ }^{279}$ Letter From the Deputy Assistant Secretary of Defense for International Security Affairs (Sloan) to the Deputy Under Secretary of State for Political Affairs (Johnson), 25 January 1964, FRUS 1964-1968, XXIV: 968-968.

${ }^{280}$ Memorandum From the Joint Chiefs of Staff to Secretary of Defense McNamara, 13 April 1964, FRUS 1964-1968, XXIV: 979-980.

${ }^{281}$ National Security Memorandum No. 295, 24 April 1964, FRUS 1964-1968, XXIV: 985.

282،U.S. Halting Arms for South Africa," New York Times, 10 October 1963, pg. 8.
} 
submarine sales. Although, one has to wonder, given the context of Stevenson's speech, and the recommendations made by the Joint Chiefs of Staff, would selling submarines have violated the embargo? Stevenson specifically stated that if the weapons were for the general defense of South Africa, that they would not be blocked. This would become an issue under the Johnson administration.

\section{Weapons Sales Under Johnson:}

President Johnson's interaction with South African weapons sales was more or less much of the same as what Kennedy did. On one hand, he acknowledged the arms embargo, but at the same time was still selling them weapons that did not overtly violate the U.S. and UN arms embargo. Johnson's administration dealt with the Roosevelt incident and retained the satellite and missile tracking stations. However, they had a favorable situation in that South Africa was continually seeking U.S. approval and trying to stay in the U.S.'s good graces due to the negativity associated with its racial policies.

Johnson's administration lacked consistency in its policy choices towards South Africa. The reality was that the arms embargo had too many loop holes and the U.S. was fearful that they would lose access to invaluable ports and tracking facilities, despite the reality that South Africa was not going anywhere, barring any major embargoes. In addition, Johnson had an administration that was split on how to deal with South Africa. One side, represented by UN Ambassador Arthur Goldberg, was that of zero tolerance. He argued that the State Department should discourage any more investment in South Africa and to try and void any existing contracts already in place. He wanted a total arms embargo, despite the fact that France was becoming a major supplier of arms. On the 
other side, Undersecretary of State George Ball opposed all that Goldberg stood for. He vehemently opposed the 1962 arms embargo because he felt that South Africa's weapons' industry and economy were developed well enough that the sanctions would not work. ${ }^{283}$

In a telegram from the Department of State to the Embassy in South Africa on January 11, 1964, shortly after Johnson took office, Rusk clarified the U.S.'s position on weapons sales. This memo provided the justification needed to skirt around the provisions of the arms embargo, thus helping establish Johnson's policy on weapons sales to the South African government. The telegram clarified that there was certainly a need to uphold the December 4 and August 2, 1963 announcements made by Stevenson at the UN to embargo arms that might be used to uphold apartheid. However, if weapons were "for maintenance of international peace and security and for the common defense effort in the interest of the world community" then it would be highly considered. In addition, the telegram points out very clearly that the satellite and missile tracking station access was contingent on weapons sales and that should the U.S. chose to fully enforce the embargo that they would most likely need to vacate with six months' notice. ${ }^{284}$

On April 24, 1964, the National Security team put out NSAM No. 295. This memo made three pivotal decisions. First, it stated that, "Existing policy regarding military sales to South African will be continued." Essentially, weapons being sold for international defense would continue to be sold, except for the submarines, which were to be postponed and considered at a later date. Second, it suspended applications for U.S.

\footnotetext{
${ }^{283}$ Coker, $12-13$.

${ }^{284}$ Telegram From the Department of State to the Embassy in South Africa, 11 January 1964, FRUS 19641968, XXIV: 966-967.
} 
government loans and investment guarantees, thus protecting what investments were already there, but preventing further investment from happening. Finally, it also gave NASA and the Department of Defense a warning that they should be ready to close up their programs and move to an alternative placement at six-months' notice. ${ }^{285}$

Not surprisingly, the Joint Chiefs of Staff were visibly irritated by it, as they felt that their views and expertise were not represented in NSAM Mo. 295. They were very concerned that it would force the South African government into having upper hand, particularly in concern to the missile and satellite tracking stations, because the U.S. had now solidified their position in supporting the arms embargo. The Joint Chiefs of Staff felt that the NSAM No. 295 would force the U.S. to follow its previous mandates to a "T" and close loopholes that already existed to allow for some sales of weapons. ${ }^{286}$ In addition, Chairman of the Joint Chiefs of Staff Maxwell D. Taylor specifically said: As long as communist penetration and racial discord in African remain an active threat to Free World interests, stability in South Africa is desirable and the United States should do everything that its political and moral position permits to contribute to this. ${ }^{287}$

The Joint Chiefs of Staff's decisions were governed by Cold War experience. They wanted the Executive branch should head their advice and curb NSAM No. 295 as the South Africa government was a very important ally militarily for the U.S., particularly in relation to port and airfield access.

\footnotetext{
${ }^{285}$ National Archives, General Records of the Department of State, RG 59, "National Security Action Memorandum,’Def 7 SAFR-US, 26 April 1964.

${ }^{286}$ Memorandum From the Joint Chiefs of Staff to Secretary of Defense McNamara, 22 May 1964, FRUS 1964-1968, XXIV: 989-990.

${ }^{287}$ Ibid, 991.
} 
The NSAM No. 295 was immediately challenged when the South African government asked Lockheed to sell them 16 P3-A ASW aircraft. This sale would total about $\$ 100$ million for the U.S. company. On August 31, 1964, the South African government informed Lockheed that if they did not sell them the aircraft, that they would instead order French Breguet Atlantique planes. The Departments of Treasury, Commerce, and Defense were all supportive of the sale, but the Executive branch was hesitant to make a move on the sale. The reality was that South Africa provided a great market for weapons sales, as it was estimated that they would potentially buy $\$ 300-\$ 400$ million dollars over the next five years on weapons. However, the NSAM No. 295 stopped and shelved all sales. ${ }^{288}$

The Lockheed sale was ultimately not approved. William H. Brubeck of the National Security Staff informed MacGeorge Bundy, the President's Special Assistant for National Security Affairs, that:

You should realize that in the eyes of almost all the world this sale associates us with the British, French, and Portuguese as helping the South Africans- and the rest of the world includes, with varying degrees of intensity, everyone from NATO partners like Norway, through Latin America to the Afro-Asians. I don't want to overstate the practical significance of this, but its symbolic and emotional impact does count for something- the racism issue is, in the long run, a real one in coping with the Chicoms. ${ }^{289}$

Clearly, diplomatic rationale trumped Cold War rationale, as provided by Taylor in the previous memo. The U.S. government was clearly walking a thin line between keeping

\footnotetext{
${ }^{288}$ Memorandum From William H. Brubeck of the National Security Council Staff to the President's Special Assistant for National Security Affairs (Bundy), 22 September 1964, FRUS 1964-1968, XXIV: 999-1002.

${ }^{289}$ Memorandum From William H. Brubeck of the National Security Staff to the President's Special Assistant for National Security Affairs (Bundy), 23 September 1964, FRUS 1964-1968, XXIV: 1004.
} 
an important ally and not forsaking their other allies in the region or in similar developmental status, such as Kenya.

A National Intelligence Estimate (N.I.E.) was published on May 20, 1964 by the CIA analysts. This largely focused on South African relations with the West and their prospects for change. The first sentence of the N.I.E. is, "The Nationalist government is firmly entrenched in power..." The N.I.E. goes on to lay out why exerting change in South Africa would be difficult if not completely fruitless, stating, "We consider it unlikely that any outside pressures brought to bear on South Africa would cause the government to alter its basic domestic policies." ${ }^{290}$ Part of the reason that the Nationalist government would not change is because they did not need to- the opposition in South Africa, such as the United Party, was divided and had such a small percentage of the vote in past elections (this is among white voters, as blacks were disenfranchised). In addition, South Africa was moving quickly towards self-sufficiency, largely driven by the gold industry and successful foreign investments. ${ }^{291}$ White South Africans did not want to change- the majority of white South Africans wanted to maintain apartheid as they benefitted greatly from it. ${ }^{292}$

The May $20^{\text {th }}$ N.I.E. discussed at length the probability of success in outside forces bringing change to South African racial policies. The CIA argued, "We consider it unlikely that any outside pressures brought to bear on South Africa would cause the government to alter its basic domestic policies." One of the reasons for the likelihood of

\footnotetext{
${ }^{290}$ Central Intelligence Agency, "Special National Intelligence Estimate: Short Term Prospects for South Africa," 20 May 1964, 1.

${ }^{291}$ Ibid, 2.

${ }^{292}$ Ibid, 4.
} 
change being slim was because the CIA was concerned that economic sanctions on South Africa would be nearly impossible to carry out. The reality was that the countries that would need to enforce the embargo were economically intertwined with South Africa, such as the U.K. The 1963 arms embargo exemplified the potential failure of a more drastic embargo. The CIA pointed out the enormous holes within the embargo that countries could literally fit a submarine through, saying:

South Africa still has little difficulty in obtaining adequate supplies of arms of all sorts. For example, arrangements have recently been made to produce small arms under license from various Western European firms.

The French, British, and Americans were able to get away with continuing to send arms so long as they were not for upholding apartheid, but rather in defense of the country. ${ }^{293}$

More specifically, the CIA felt it highly unlikely that the U.S. would want to establish and uphold a more stringent embargo. They had many reasons to put off establishing a loftier embargo. At the top of that list was the missile and satellite tracking station. Also, the U.S. had over $\$ 600$ million of private investment, which was seen as a source for considerable leverage by the South Africans. ${ }^{294}$ In addition, the U.S. liked having access to naval ports in the post-Suez crisis world. Like the British and the French, the U.S. was too entwined economically to effectively enforce an embargo.

In 1965, a National Policy Paper on South Africa clearly laid out the economic and military prowess the South African government had in the region and with its trading partners. Their military had emerged to be fully modernized and efficient on the ground, air, and sea. Ultimately, their goal was to be completely self-sufficient economically and

\footnotetext{
${ }^{293}$ Ibid, 5-6.
}

${ }^{294}$ Ibid, 6-7. 
militarily. Their shortages in basics were in petroleum products, some automotive and airplane parts, wheat, cotton, and rubber. However, they did produce over $50 \%$ of the world's gold and sold large amounts of its uranium to the U.S. and U.K., thus creating a situation in which they could trade for the materials they needed. And trade they did, not only in gold and uranium, but also livestock, sugar, wool, and fruit. In addition to trade, the South African government encouraged foreign investment to help obtain their goal of self-sufficiency. The British exceeded over \$3 billion in investment, while the U.S. had over $\$ 600$ million. Businessmen found it agreeable to invest there, as they had very high returns on their investments. ${ }^{295}$

The National Policy Paper contemplated what appropriate steps the U.S. should take in South Africa in order to retain the international community's good graces but also to maintain investments and maximize from a supple market:

Difficulties of enforcement, adverse effects on the people of South Africa as well as the race relations situation, and the consequences for other countries, such as the UK, all need more searching analysis that is currently being undertaken in the Department of State.

Ultimately, the National Policy Paper laid out a series of questions for which there was no easier answer:

Should the US avoid intervention in South Africa because the short-term situation is relatively stable and might be worsened by interference? Should the US join in treatment of South Africa as a pariah nation and back up this condemnation with pressures going beyond the arms embargo? Is apartheid so dangerous to international order in Africa and so susceptible to Communist exploitation that the US must seek ways to resolve the issue? ...Are there constructive ways in which the US and its allies can show South Africa a path toward racial harmony? ...Failing these, should we progressively dissociate the US from South Africa with respect to arms, space, investment, trade and cultural relations? ${ }^{296}$

\footnotetext{
${ }^{295}$ National Policy Paper, 18 January 1965, FRUS 1964-1968, XXIV, Web.

${ }^{296}$ Ibid.
} 
These questions ultimately shaped the issues that Kennedy, Johnson, and Nixon's administrations dealt with when discussing weapons sales, the satellite and tracking stations, and the use of naval ports. The South African government had so much to offer as an ally during the Cold War that apartheid almost became forgivable, even during the height of the Civil Rights Movement.

Regardless of NSAM No. 295 and the National Policy Paper, the sale of weapons continued. Despite the Joint Chiefs of Staff being concerned that NSAM No. 295 and the embargo would ultimately close any loopholes to allow for weapons sales, the loopholes still existed. It is essential to remember that the original arms embargo, as stated by Stevenson in front of the UN, allowed for the sale of weapons so long as it was for the national defense of South Africa. NSAM No. 295 did not change this. The arms embargo and NSAM No. 295 would be tested in 1966-1967 with the approval of sales for Cessnas to South Africa.

On February 21, 1966, the sale of eight Cessna Aircraft (Model 411), worth $\$ 1.5$ million, was discussed at length by the State Department and National Security Affairs. It is questionable as to why these eight Cessnas were a cause for concern, as 50 Cessnas had already been approved for sale, totaling \$39 million in sales. The State Department made two very solid arguments as to why the Cessnas should not be sold. First, the intent for the use of the aircraft was to survey and locate smugglers, as they were equipped with a special type of radar. They were not for an external threat. This would very clearly violate the UN arms embargo of 1963 . Second, it would have been be very easy to use these weapons in an unintentional way, such as to enforce apartheid among its 
population. ${ }^{297}$ It is clear that the U.S. State Department was fearful not only of violating the arms embargo, but that their weapons would be directly used to enforce apartheid, which could have been a political nightmare for the U.S.

Even though the Cessna sale was denied, presumably because of the embargo, it did provoke a conversation about the extent to which other countries were following the UN arms embargo, such as the U.K., France, and Italy. On December 20, 1967 Under Secretary of State for Political Affairs Rostow informed Under Secretary of State Katzenbach, Rostow that, "The basic problem is that we adhere to a more restrictive interpretation of the Security Resolution that most other countries, while France openly ignores it." What prompted this concern were the sales of the French Mystere aircraft, the Italian Piaggio aircraft, and the British Beagle 206 civilian aircraft. The Mystere jet and Piaggio aircraft had U.S. engines and/or components in them, so the U.S. was concerned, should they be following the arms embargo as it were stated, that they were violating it. More importantly, it was unclear what the intent of the need for the weapons were for South Africa. This created a difficult situation for the U.S.:

The net result is that the U.S. balance of payments suffers, the British balance of payments suffers, we create friction with our European allies and give de Gaulle another chance to say that you cannot do business with the United States without ending up having the United States dominating your foreign policies.

Thus, it was recommended by Rostow to move towards a "more realistic application of the arms embargo," in particular that was more in line with the British who were at least attempting to justify the sales by saying they were for the defense of South Africa. ${ }^{298}$

\footnotetext{
${ }^{297}$ Memorandum From the Under Secretary of State for Economic Affairs (Mann) to the President's Deputy Special Assistant for National Security Affairs (Komer), 24 February 1966, FRUS 1964-1968, XXIV, Web.
} 
On February 17, 1967, UN Ambassador Goldberg wrote a letter to Secretary of State Rusk stating his views on how to handle South Africa. He strongly felt that the U.S. would be hurting not only themselves diplomatically if they continued to have any sort of relations with the South African government, but the South Africans themselves. He felt that is was far more important to protect their interests on the continent of Africa over retaining relations with the South African government. Moving away from their government was the U.S.'s only viable choice because Goldberg felt that U.S. persuasion of the South African government was minimal at best. Pertaining specifically to weapons sales, he said that the U.S. should:

Continue strictly to enforce the arms embargo including, as we have in the past year, embargo of all dual purpose equipment for South African military, such as trucks and executive-type aircraft for VIP transport, whether others do so or not. At the same time, we should take whatever steps we can to assure that the arms embargo is similarly observed by South Africa's other trading partners and that orders not filled United States suppliers are not thereby lost to competitors. ${ }^{299}$

It is unclear how Rusk took the advice from his UN ambassador, but based on events that followed, it seems as if the advice fell on deaf ears. Whereas Goldberg was more concerned about U.S. relations with the rest of the continent, other various government officials were more concerned with the lack of adherence the other countries gave to the UN embargo and its impact on U.S. private investment and access to ports and airfields, as discussed previously. In addition, particularly under Nixon, it was felt that the U.S. must retain connections to the South African government because they could influence

\footnotetext{
${ }^{298}$ Memorandum From the Under Secretary of State for Political Affairs (Rostow) to the Under Secretary of State (Katzenbach), 20 December 1967, FRUS 1964-1968, XXIV, Web.

${ }^{299}$ National Archives, General Records of the Department of State, RG 59, "Letter to Dean Rusk from Arthur Goldberg,'Def 12-5 SAFR, 17 February 1967.
} 
their race relations positively, as expressed in NSSM 39, which will be discussed in the next section.

On May 4, 1967, CIA analysts produced a second N.I.E. on South Africa. While the N.I.E. largely focused on the issues South Africa was having with its sub-Saharan neighbors, it did broach the subject of weapons sales. The N.I.E. stated:

South Africa especially wants to improve relations with the US and, if possible, to obtain some expression of US approval for its attempts to appear more flexible. It will probably permit the US to use present space and tracking installations at least during the period of this estimate, provided that the US does not participate in significant sanctions against South Africa. We believe, however, that the whites will hold steadfastly to their policy of white dominance and that significant changes in South Africa's policies either in response to domestic developments or external pressures are highly unlikely in the next five years. ${ }^{300}$

This statement generalized a steadfast belief that would structure much of the policy choices around U.S.-South African relations.

In the N.I.E., the CIA addressed their relations with the west, more specifically, the U.S., U.K., and France. The N.I.E. stated that, "South Africa values its affiliation with the West and never fails to stress its strong anticommunism and its present and potential importance to the West in military and strategic terms."301 There are repeated examples to confirm this in the chapters on the Roosevelt incident and the use of the tracking stations. In fact, the CIA felt that Vorster's government was trying campaign specifically to the U.S. government to get greater sympathy for their plight and their attempts at reform. They did not need to campaign so heavily to the U.K. and France for several reasons. The U.K. had self-interest in deterring UN measures for sanctions against South Africa because it would have seriously damaged the balance of payments

\footnotetext{
${ }^{300}$ Central Intelligence Agency, "National Intelligence Estimate: South Africa," 4 May 1964, 2.

${ }^{301}$ Ibid, 15.
} 
owed to the U.K. France benefitted greatly from the embargo because they had begun to make significant amounts of money off of South Africa's military needs. They stood to make an estimated $\$ 90$ million annually in sales from the South Africans, selling them such things as armored cars, electronic equipment, Mirage II jet aircraft, helicopters, and submarines. Regardless of the close ties to the British and French, the South African government still sought out the best relations with the U.S. because they regarded the U.S. as "the leader of the West and the first line of defense against communism." They wanted to encourage U.S. trade and investment and were willing to provide the U.S. with access to the space and tracking stations so long as there were no major sanctions placed against them by the U.S. ${ }^{302}$

France was making serious economic gains on weapons sales to South Africa. The French Consul General Romain Vuillaume met with the U.S. Consulate in Athens to discuss weapons sales. Even though he said he would deny it publicly, Vuillaume confirmed that the French government traded a significant amount of weapons- 100 aircraft, over 100 AMX tanks, two destroyers, and large quantities of other war materialsfor gold, as the gold market was doing very well. When he was asked how France would manage such a large order, Vuillaume commented that they would "renege on other commitments if necessary which were either already made or were reportedly in process...." Vuillaume offered a similar argument that was echoed in the halls of the U.S. State and Defense departments, which was that continued relations with the South

\footnotetext{
${ }^{302}$ Ibid, 15-16.
} 
African government might enable them to have some sway over their domestic and international policies. $^{303}$

A few months after the N.I.E. was published, it was found that a significant amount of napalm and other dangerous chemicals were being produced at a plant in Umbogintwini, Natal using U.S. machinery and parts. Even though U.S. citizens were not necessarily employed at the M.W. Kellogg Company’s (Kellogg's international branch) sites in South Africa, they were there supervising the construction and operation of an ammonia processing plant when they discovered, using "infra-red analyzers," that there had been some testing of bombs using nitrogen, methane, and ammonia. Much of the reporting on the explosives development and testing was reported by Ray Browne, an “instrumentation superintendent” working with M.W. Kellogg Company to help construct and operate ammonia processing plants in South Africa. He reported, " "There are 2,500 pounds of liquid ammonia,' and various other low flash point chemicals and fuels that "could do a lot of damage if they got loose..." In addition, even though they had not observed any blasts, suspicious materials shipments to and from the plant had workers on high alert. ${ }^{304}$

Not only was the U.S. State Department worried about the weapons production, but they were worried about the extent that private U.S. companies were involved with the production of materials such as napalm. In addition to Kellogg designing and implementing usage of the plants, Motorola, Pacific Pumps, Mercoid Corporation, The

\footnotetext{
${ }^{303}$ National Archives, General Records of the Department of State, RG 59, "France and the Gold Markey,’Def 12-5 SAFR, 18 March 1968.

${ }^{304}$ National Archives, General Records of the Department of State, RG 59, “AE \& CI at Umbogintwini Making Munitions- Napalm and Possibly Up to Twenty Ton 'Blockbusters','Def 12-5 SAFR, 21 July 1967.
} 
Foxboro Company, Belco, and other various companies all helped contribute elements that went into the processing plant. The high pressure tanks, centrifuges, the motors, the pumps, the governor valves, all control equipment, walkie-talkies, and round storage tanks were all provided by U.S. companies. It is unclear how much help South Africa got from these companies, other than purchasing it, but it is fair to assume that some help in assembly may have transpired, by Kellogg or the companies themselves. ${ }^{305}$ This is a minor, but informative, blip on the weapons sales screen because it points to a weakness in the arms embargoes and policies passed by various presidents- that of private corporations looking to sell their products, despite what might be built with it.

On February 10, 1968, Goldberg received a note from Joseph J. Sisco, the Assistant Secretary of State for International Organization Affairs. It was revealed that U.S. policy reaffirmed the decision, and recommendation by Goldberg, that U.S.manufactured aircraft and aircraft components would still not be sold to the South African government. This was in reference to the sale of Mystere 20 aircraft that was sought by the South Africans. While this decision seems very clear, it was followed immediately with the decision that U.S.-made components would still be exported to "third countries" for re-exportation to South Africa in finished products, so long as the finished products were not of a "weapons nature"”. In addition, there was a "Grey Areas Committee" that met to decide on whether or not the "third country" weapons components would visibly violate the embargo, because if they did the, sale would be

\footnotetext{
${ }^{305}$ Ibid.
} 
denied. $^{306}$ This letter is extremely significant because it very strongly alludes to the fact that the U.S. government under Johnson still wanted to sell weapons to the South African government so long as they did not get caught for violating the embargo. It also mentioned a "Gray Areas Committee," which was never mentioned previously, whose job was seemingly to erase "Made in U.S.A" labels from components used on potential weapons sold to the South African government.

The letter from Sisco to Goldberg barely preceded Senate Congress Resolution 60, produced February 28, 1968, which further opened the door to weapons sales to South Africa, much to Goldberg's demise. The resolution offered eight reasons to loosen the arms embargo on South Africa. Among these eight reasons included recognizing South Africa as an important ally in the Cold War diplomatically, that the U.S. may need to rely on their ports and trade routes should another Suez crisis occur, and their allowance for use of naval ports and airfields, particularly for the satellite and missile tracking stations. Ultimately, they proposed:

That it is the sense of the Congress of the United States that the United States Government immediate cease its unfair, harmful, arbitrary, and costly policy of prohibiting the sale of military goods to the armed forces of the Republic of South Africa in keeping with the needs of the Republic of South Africa in maintaining her defenses against aggression and to allow the Republic of South Africa to be military prepared to defend sea routes, coastline, and other areas vital to maintaining peace in the world, and to allow the Republic of South Africa to continue effective support as an ally to the United States. ${ }^{307}$

Congress essentially gave the U.S. State Department the okay to go ahead and sell weapons directly, or indirectly through "third countries" to South Africa, as they saw it

\footnotetext{
${ }^{306}$ National Archives, General Records of the Department of State, RG 59, "Letter to Arthur J. Goldberg from Joseph J. Sisco,’Def 12-5 SAFR, 10 February 1968.

${ }^{307}$ National Archives, General Records of the Department of State, RG 59, "Letter from J.W. Fulbright to Dean Rusk,"Def 12-5 SAFR, 4 March 1968.
} 
vital to positive relations with the South African government diplomatically and militarily.

Under Johnson's leadership, hundreds of millions of dollars' worth of weapons were sold to the South African government by the U.K., France, Italy, and U.S. The British made ten-year contracts worth $£ 200$ million. This included 16 Buccaneer strike aircraft, eight Nimron maritime reconnaissance machines, four missile frigates, six HS125 light jet transports, as well as ship-to-air missiles, radar, and other equipment. ${ }^{308}$ The French flagrantly sold $\$ 100$ million worth of weapons, including Mirage jets, Alonette helicopters, AMX tanks, Panhard armored cars, and Daphne-class coastal submarines. ${ }^{309}$ The U.S. also sold their share of weapons, including 22 Cessna Model185 light planes, Lockheed C-130 Hercules transports, and AL-60 single-engine transports. In addition to directly selling their own models, the U.S. supplied major components, such as engines, to Italian aircraft that were sold to South Africa, including the Piaggio P-166, the AerMacchi Am-3C, and the Atlas C-4M. ${ }^{310}$ Despite weapons being sold, it could be argued that the U.S. had some sort of political conscience to at least discuss the fact that weapons were being sold despite a U.S. government imposed embargo in 1963, a UN embargo in 1964, and a restatement of embargo by the U.S. State Department in NSAM No. 295. Regardless, the U.S. Executive branch skirted around the embargo because they feared political reparations from the South African government concerning their access to ports and the satellite and missile tracking stations.

\footnotetext{
${ }^{308}$ Cynthia C. Kahn, “Arms Embargo on South Africa Still and Issue,” Africa Today 15, no. 3 (1968): 5-6.

${ }^{309}$ Lloyd Garrison, "France Increases South Africa Ties," New York Times, 27 March 1968, p. 7.

${ }^{310}$ Michael Klare and Eric Prokosch, "Evading the Embargo: How the U.S. Arms South Africa and Rhodesia," Issue: A Journal of Opinion 19, No 1/2 (1979):42-44.
} 


\section{Weapons Sales Under Nixon:}

With Nixon's swearing in as president in 1969, he too found himself struggling with U.S. foreign policy in weapons sales and base usage in South Africa. The Department of Defense, namely the Chiefs of Staff, highly praised the South African government's aid in the global war against communism. They wanted to keep open the avenues of communication created by weapons sales in exchange for base access. On the other side, there was a softer voice that argued the U.S. government should not be selling the South African government weapons, nor should they be utilizing their bases, as the argument for change via monetary influence was a bad myth. Nixon's response was to unleash Kissinger and the National Security Council on the problem, thus producing NSSM-39.

Upon discussing NSSM-39, there were five proposals set forth in December 1969, prior to the publication of NSSM-39. Option one called for closer association with the white regime in order to better protect the U.S.'s economic and strategic interests. Option two sought closer relations with Pretoria in an effort to persuade it to move its political system towards reform. Option three wanted highly limited cooperation with the South African government in an attempt to safeguard its economic investments while saving face in front of the international community. Option four suggested total disassociation with Pretoria and closer relations with black nationalists. And, finally, 
option five wanted disassociation from both sides in order to become disentangled from a problem that only was projected to get worse despite the west's best efforts. ${ }^{311}$

Through time, it became evident that the first, fourth, and fifth options were not agreeable by any department's standards. While the State Department preferred option three because they believed constructive engagement would not work, Roger Morris, the architect of NSSM-39, Nixon and Kissinger all highly recommended option two because they believed that change to apartheid would ultimately only come through them. ${ }^{312}$ One historian, Joan Hoff, felt that option two was racially motivated, saying that it was "the racist 'tar baby' policy adopted for all of Africa in 1970 favoring cooperation with white minorities against black nationalist movements...."313 Whether or not it was racism or some other driving factor, option two became the option of choice because white minorities were seen as being permanent, whereas black nationalists could only find success through violence or extreme political measures, such as communism, thus making white minorities the only viable choice to support. ${ }^{314}$

Given the economic implications of doing anything but working with the South African government, it was no surprise that the root of NSSM-39 became option two. At the time that Nixon came into office, South Africa was the U.S.'s $15^{\text {th }}$ largest capital market, even though it only accounted for $2 \%$ of its total overseas earnings. The thirteen largest companies in the U.S. owned $25 \%$ of all U.S. investment in South Africa. Also, South Africa was responsible for providing the U.S. with six of its 35 most important

\footnotetext{
${ }^{311}$ Coker, 19.

${ }^{312}$ Massie, 236.

${ }^{313}$ Joan Hoff, “A Revisionist View of Nixon's Foreign Policy,” Presidential Studies Quarterly 26, no. 1 (1996), 116.

${ }^{314}$ Paul Rich, "United States Containment Policy, South Africa, and the Apartheid Dilemma," Review of International Studies 14, no. 3 (July 1988), 184.
} 
commodity imports, including ferrochrome metals, manganese, chromium, and vanadium, (all of which are used to make stainless steel) and nonferrous metal fluorspar (helps purify steel), and platinum (used to modify and strengthen various types of metals). ${ }^{315}$ In addition, over 300 U.S. companies had invested there, thus helping the United States to have a healthy trade balance with imports totaling over $\$ 600$ million and exports equaling $\$ 1,160$ million by $1974 .{ }^{316}$

Nixon did face an elevation of tactics used in apartheid by Pretoria, which may have made discussions around how to handle the relations more complicated. By Nixon's inauguration, South Africa had over 6,000 laws and 4,000 regulations, 60 public statutes, and a full-fledged system of legal detention that was used to keep blacks disenfranchised and disempowered. ${ }^{317}$ After 1968, Prime Minister John Vorster was seemingly determined to separate development with an increased vigor; he wanted the black majority to live on homelands separate from whites. Even though black South Africans constituted $85 \%$ of the population, Vorster wanted them moved onto $13 \%$ of the land. ${ }^{318}$ Vorster justified the moving of blacks onto the nine different Bantustans as a return for them to their "homeland." In reality, black South Africans faced being uprooted from their homes in urban areas to a "homeland" many of them had never seen. Also, there were not enough jobs in the Bantustan locations. ${ }^{319}$ Unfortunately for Vorster, jobs that relied on lower waged workers, black Africans, were located in

\footnotetext{
${ }^{315}$ Coker, 25.

${ }^{316}$ Donald B. Easum, "United States Policy Toward South Africa," Issue: A Journal of Opinion 5, No. 3 (1975), 67.

${ }^{317}$ Coker, 65 .

${ }^{318}$ Ibid, 71-72.

319،'South Africa Will Give Blacks 'Homeland' Citizen Papers,” New York Times, 10 April 1969, pg. 3.
} 
industrial centers away from the Bantustans. The act of total segregation was impossible for Vorster as it would have unintended consequences of removing the cheap labor that wealthy white South Africans so heavily relied on. ${ }^{320}$

By July 1970, African states had enough of the continued sales of weapons to the South African government and pushed the UN to tighten its embargo on weapons to South Africa. In a vote 12-0 on July 23, 1970, the UN approved Resolution 282, the prohibition the sale of equipment or vehicles that could be used by the military. The rationale for the bills was that the resolve of the arms embargoes from Resolutions 181, 182, and 191 dissolved at a rapid pace resulting in a heavily armed South African Defense force. Resolution 282 reiterated the previous resolutions and broadened its conditions. $^{321}$ It included the ban of sales of spare parts, patents, and licenses for arms, aircraft, and naval vessels. It also called for a ban against training South African forces by UN member nations. ${ }^{322}$ The resolution also very specifically stated, "Calls upon all States to strengthen the arms embargo by implementing fully the arms embargo against South Africa unconditionally and without reservations whatsoever..." The U.S., U.K., and France all abstained from the vote. ${ }^{323}$

Regardless of increasing apartheid laws and the passing of Resolution 282, Nixon still believed that option two of NSSM-39 was the best policy to implement regarding South Africa. He, and Kissinger, made it clear that economic sanctions were not going to work and that they should be avoided. However, an arms embargo was a different matter

\footnotetext{
${ }^{320}$ Tertius Myburgh, “South Africa's Ruling Party, in Power 21 Years, Is Shaken By Feuds and Pressure to Widen Apartheid," New York Times, 27 May 1969, pg. 13.

${ }^{321}$ “U.N. Security Council Resolution on Arms Embargo Against South Africa," International Legal Materials 9, no. 5 (Sept. 1970), 1091-1092.

${ }^{322}$ Kathleen Teltsch, "Embargo on Arms Tightened By U.N.” New York Times 24 July 1970, pg. 7.

323،U.N. Security Council Resolution on Arms Embargo Against South Africa," 1092.
} 
and was thus handled separately despite NSSM-39. ${ }^{324}$ In 1970, Nixon set out to resolve the "gray area" issue of the 1963 arms embargo. The result was National Security Decision Memorandum 81 (NSDM 81). In the August 17, 1970 memo, Nixon made it clear that the U.S. was going to stick to the original 1963 arms embargo, but that some clarification was needed. In NSDM 81, it specifically stated that nonmilitary dual-use items which were "preponderantly employed for civilian use" would be manufactured without military specifications. Also:

Non-lethal dual-use items which are preponderantly used by military forces, but which do not have a clear and direct application to combat or to internal security operations, will be licensed for sale to civilian purchases for civilian use, and may be licensed to military buyers... Such items will be built to military specifications.

However, dual-use items that had a "clear and direct application to combat or internal security operations (including aircraft suitable for troop transport), will not be licensed to military buyers." Under such guidelines, Nixon allowed the sale of Lear jets and Cessna dual-engine 401s and 402s to the South African Defense Forces. However, Cessna single-engine 180/ 185s, Lockheed Orion P-3Cs, and L-100 aircraft were not to be sold to SADF. $^{325}$

While NSDM 81 did try to clarify the so-called "gray area" sale of weapons, it still allowed for the sale of some very serious weapons. During the 1970s, under Nixon, Ford, and Carter, the U.S. sold South Africa M-47 tanks, Commodore V-150 and M-113 AI armored personnel carriers, M-109 155mm self-propelled guns, 205A Iroqouis helicopters, Lockhead F-104FGA/ Interceptor, Lockhead L-100 transport, Augusta Bell

\footnotetext{
${ }^{324}$ Coker, 33.

${ }^{325}$ "National Security Decision Memorandum 81" Federation of American Scientists, Web, March 22, 2011.
} 
205 A helicopter, M-47 Patton I Tank, M-113 AI armored personnel carrier, V-150/200

Commando personnel carrier, and M-109 $155 \mathrm{~mm}$ self-propelled guns. ${ }^{326}$ With the sale of such weapons, it is unclear what NSDM 81 had planned to accomplish, other than allowing civilians to buy and use planes that had military capabilities so long as they were not manufactured to military specifications.

In addition to continuing to sell weapons to the South African government, the U.S. State and Defense departments also continued to train South African Defense Forces. In October 1970, the question of how to deal with continued training of the SADF via training films and direct contact was discussed at length. In the memo it was suggested, and eventually accepted, that the U.S. would continue to sell unclassified defense training films to the SADF. In addition, SADF military personnel could participate in military correspondence classes so long as they were unclassified, could not be applied to internal security of South Africa, and were not related to combat training. They could take classes in the areas of economics, management, law, and safety and health. Finally, visits of SADF military personnel was to be kept at a minimal and with the guidelines that it was not for training that could help with their military capacity and/ or if it significantly helped U.S. objectives. ${ }^{327}$ Although visits appeared to be curbed by the U.S., it is still in direct violation of U.N. Resolution 282, which stated, “... by ceasing provision of military training for members of the South African armed forces and all other forms of military co-operation with South Africa." ${ }^{328}$ It is unclear how many

\footnotetext{
${ }^{326}$ Coker 105-107.

${ }^{327}$ National Archives, General Records of the Department of State, RG 59, "Relations with South African Military Establishment,’Def 1 SAFR-US, 19 October 1970.

328،U.N. Security Council Resolution on Arms Embargo Against South Africa,” 1092.
} 
members of the SADF visited the U.S. during this time and for what purposes and how many unclassified Department of Defense training videos were purchased.

The arms embargoes over Kennedy, Johnson, and Nixon's presidencies were influenced for an implicit concern about apartheid. While the Joint Chiefs of Staff were very concerned about the implications of the embargo on the global Cold War, the Executive branch seemed more concerned with their continued access to the South African ports and satellite and missile tracking stations and protecting investment within South Africa. Even CIA analysts recognized that there was a minimal risk of the Cold War rearing its head in the South African government in the form of black nationalists. Regardless of the increasing restrictions of apartheid, the U.S. government continued to sell weapons to South Africa in a vain attempt to influence the government, but more likely to retain its economic, scientific, and military interests in the region, as they were far more valuable in the context of the global Cold War than the ill-perceived threat of communism or Soviet threats spreading in to South Africa via black nationalists.

Ironically, it was the U.S. under Kennedy that began to scrutinize the South African policy of apartheid after Sharpeville and ultimately propose an arms embargo. However, the U.S. allowed for loopholes to exist within its embargo so that the sale of conventional weapons, such as planes, tanks, and spare parts, could be sold, thus giving the South African government the illusion that the U.S. was at least temporarily okay with the enforcement of apartheid. The stipulation was that the weapons had to be for international security and not to be used for domestic implementation of apartheid, however this was never seriously upheld, except in times when weapons sales were 
leaked to the press. This clearly was violated as Nixon addressed it within the Grey Areas Committee and produced NSDM-81, which allowed weapons to continue to be sold to civilians so long as intention for weapons were not to wind up with the government and used for domestic enforcement of apartheid. There was also concern that the British, French, and Italians were so flagrantly violating the UN arms embargo that why shouldn't the U.S. do the same? The U.S. Executive branch saw the advantages to selling weapons but feared public reprisal for violating the arms embargo, so they continued to be subversive in their weapons sales, selling weapons to civilians and third parties and selling components to be used in British, French, and Italian planes, arms, and tanks.

The loopholes within the embargo are due to the global Cold War context. South African leaders when requesting weapons would reference themselves as being on the front line of keeping the communists at bay. In addition the loophole specifically called for weapons to be sold for international conflict. It could be argued that the loophole existed to allow for weapons sales should, for example, the Soviets actually made headway into the newly formed African nations and became a major threat on the continent. However, this was unrealistic and was not the probably rationale behind loopholes existing in the UN and U.S. embargoes. Rather, weapons served as a means to maintain access to ports and satellite tracking stations. 


\section{Conclusion}

The three case studies examined in this thesis reveal a complex and dynamic relationship between the U.S. and South African governments, between the different branches of the U.S. government, and within the U.S. Executive branch itself within the context of the global Cold War. Previous notions of the U.S. foreign policy decisions being based solely on the tradition Cold War structure must be reexamined for accuracy. The United States sought to maintain normal relations with South Africa by making and breaking arms embargoes to keep its access to ports, tracking stations, and economic investments despite the enormous human rights violations that were occurring in South Africa. South Africa was an ally for the U.S. during a global war, despite the political implications being a regional ally with an overtly racist country could bring, particularly during the Civil Rights era. However, the reasons for South African remaining an ally in the face of apartheid were not as simple as promoting democracy in the face of an aggressive Soviet charge in Africa or South Africa representing a proxy war in Africa. Rather, South Africa was a vital ally in the global Cold War and maintaining friendly relations with them resonated past the borders of South Africa.

Prior historical work on U.S.-South African government relations suggest a multitude of conclusions, depending on the historian consulted. Whereas Thomas Borstelmann and Robert Kinlock Massie contextualized the U.S. Executive branch decisions in the context of fear towards Soviet-backed communist expansionism, other historians, namely Sue Onslow and John Daniel, found that this contextualization oversimplified relations between the two countries during the Cold War. To address the practicality of a communist threat, Christopher Andrew and Vasili Mitrokhin argued that 
the ANC and SACP only received modest support from the Soviet Union and where therefore never a threat to the South African government. Although in agreement that a communist revolution was impractical in South Africa Vladimir Shubin saw the Soviet influence as a threat that was thwarted by logistics, such as getting the soldiers trained in guerilla combat in Odessa back into South Africa undetected.

This thesis set out to understand the depth of the significance of South AfricanU.S. governmental relations in the context of the Cold War. While it aligns itself with the conclusions of Onslow and Daniel, it adds to the historiography by contributing to our understanding of why the Executive branch chose to support apartheid despite growing domestic and international concern for doing so in the U.S. The case studies selected for this paper from the National Archives clearly highlights the importance of having good relations with the South African government to maintain a vital ally in sub-Saharan Africa in the context of the global Cold War.

South Africa as part of the global Cold War was not a simple U.S. versus the U.S.S.R. conflict. This research revealed how many ambiguous layers made decision making difficult for the U.S. government in all of its branches. In many ways, the South African government was a perfect ally for the U.S., particularly in the face of the threat of the domino theory in Southeast Asia and Africa. They were a modern country situated in a region traversed by U.S. naval ships. They had ports that could be highly beneficial to them should the Suez be closed to U.S. access again. They were a crucial location for monitoring space flights and satellites. However, they employed apartheid, a ruthless manner of ruling the black majority. How could any of the branches of the U.S. 
government support apartheid South Africa, particularly given the domestic framework of the Civil Rights Movement that was reaching its peak during this time period?

The answer is not simple, nor is it clear. The U.S. Executive branch often framed their policies based on prior decisions. If the U.S. chose not to dock ships in South Africa, what would this mean for the use of other ports, in particular the ones used for satellite and missile tracking? If the U.S. stopped collaborating with South Africa scientifically, what did this mean for advancements in the ambitious goal of landing a man on the moon by 1970? If the U.S. stopped selling weapons to South Africa, what did this mean for maintaining access to shipping yards that could handle the high-level needs of U.S. naval ships that needed clean access to the Indian Ocean? In reviewing diplomatic papers during this time period, it is clear that policy choices involving South Africa were slow and hypocritical.

Decisions about ports usage, support for NASA, policy papers such as NSSM-39, and the continued sale of weapons despite the arms embargo reveal the disregard the U.S. had towards apartheid in making its decisions. Ethics played little, if any, part in decision-making. Public image, on the other hand, was of a high concern for the U.S. State Department, Department of Defense, Executive branch, and Congress, particularly with the domestic issues of the Civil Rights Movement and Vietnam War hampering many of the decisions they made towards the region.

Access to the naval and outer space stations was tied to the sale of weapons to the South African government. While there is no solid document that states as much, it is eluded to in several policy memos in the State Department. The sale of weapons is the glue that held access to the South African government together for the U.S. The U.S. did 
not sell weapons to South Africa to keep the Soviets from penetrating; rather, weapons were sold to the South African government to maintain amicable status to ensure access to bases and tracking stations, which was more vital to U.S. efforts in the global Cold War. This notion goes above and beyond previous scholarship that regards U.S. foreign policy choices based largely (or solely) on concerns related to the Soviets in the Cold War.

Further research on U.S.-South African relations during the global Cold War is necessary. Whereas this thesis looks closely at the State Department, Congress, and the Department of Defense based on Record Group (RG) 59 of the National Archives (Department of State papers) and the Congressional Record, future research pertaining to U.S. foreign policy decisions should look at papers concerning the Department of Defense (RG 330), U.S. Senate (RG 46), House of Representatives (RG 233), Joint Committees of Congress (RG 128), National Security Council (RG 273), the CIA (RG 263), Joint Chiefs of Staff (RG 218), the Department of the Navy (RG 340, 341), and the Department of the Navy (RG 38, 80, 340, 428). These were all selected because of the prominence their departments were afforded in State Department documents regarding South African relations. Looking into these archives may help illuminate further complexities among the branches and wings of government involved with determining foreign policy towards South Africa. Further research in the Archives will hopefully reveal further case study history that illustrates U.S. policy choices and the conflict, or agreement, various segments of the U.S. government had in producing policy towards the South African government. 
In addition, to create a clearer South African perspective, it is imperative to access South African archives to view Presidential, Presidential Cabinet, and Parliamentary papers to discern the complexity of the global Cold War from the South African government's perspective. Papers of the ANC would also help create a more substantial and holistic picture of South Africa's domestic conflict in relation to the global Cold War. Finally, to look more in-depth at port availability and the impact of weapons sales to the South African government on southern Africa, access to other African state's archives, such as Kenya, would be necessary.

This thesis expands on current scholarship that has only begun to suggest that U.S.-South African relations is not merely structured on traditional definitions of the Cold War, those often being heavily influenced by the role of Soviet expansionism or the fear of communism spreading throughout South Africa. Rather, it is important to look at specific examples of the two governments interacting to illuminate the complex relationship between them. Through these examples, it becomes much clearer that the U.S. sought to maintain a positive relationship with the South African government so that they could keep an important ally in the global Cold War. Further research conducted on the premise of this thesis will hopefully reveal more examples of South Africa's importance to the U.S. as a global Cold War ally and clarify the exact intentions, goals, and perceptions the U.S. government had with the South African government. 


\section{Bibliography}

Archives and Primary Documents

Central Intelligence Agency. "National Intelligence Estimate: Probable Developments in the Union of South Africa." 20 October 1952.

---. "National Intelligence Estimate: South Africa." 4 May 1967.

---. "The Political Situation in the Union of South Africa.” 31 January 1949.

---. "South African Politics and US Security.” 17 November 1950.

---. "Special National Intelligence Estimate: Short-Term Prospects for South Africa.” 20 May 1964.

Congressional Record. $90^{\text {th }}$ Cong. $1^{\text {st }}$ sess., 1967. Vol. 113, pt. 2: 1423-2878.

---. $90^{\text {th }}$ Cong. $1^{\text {st }}$ sess., 1967. Vol. 113, pt. 14: 17891-19342.

---. $90^{\text {th }}$ Cong. $1^{\text {st }}$ sess., 1967. Vol. 113, pt. 18: 23451-24928.

---. $90^{\text {th }}$ Cong., $1^{\text {st }}$ sess., 1967. Vol. 113, pt. 24: 32117-33596.

---. $91^{\text {st }}$ Cong., $2^{\text {nd }}$ sess., 1970. Vol. 116, pt. 25: 33259-34492.

---. $92^{\text {nd }}$ Cong., $2^{\text {nd }}$ sess., 1972. Vol. 118, pt. 11: 13301-14556.

National Archives. General Records of the Department of State. RG 59.CSM 11SAFR.

---. General Records of the Department of State. RG 59. Def 7- SAFR-US, 1967-1969.

---. General Records of the Department of State. RG 59. Def 12-5 SAFR, 1967-1969.

---. General Records of the Department of State. RG 59. Def 12-5 SAFR, 1970-1973.

---. General Records of the Department of State. RG 59. Pol 23-8 SAFR, 1970-1973.

“Operation Mayibuye.” The Rivonia Trial. 3 May 2011. http://law2.umkc.edu/faculty/projects/ftrials/mandela/mandelahome.html.

U.S. Department of State. Foreign Relations of the United States, 1958-1906. Vol. XIV: Africa. Washington, D.C.: U.S. Government Printing Office, 1992.

---. Foreign Relations of the United States, 1961-1963. Vol. XXI:Africa. Washington, 
D.C.: U.S. Government Printing Office, 1995.

---. Foreign Relations of the United States, 1964-1968. Vol. XXIV: Africa. Washington, D.C.: U.S. Government Printing Office, 1999.

Books

Andrew, Christopher and VasiliMitrokhin. The World Was Going Our Way: The KGB and the Battle for the Third World. New York: Basic Books, 2005.

Berger, Iris. South Africa in World History. New York: Oxford University Press, 2009.

Borstelmann, Thomas. Apartheid's Reluctant Uncle: The United States and Southern African in the Early Cold War. New York: Oxford University Press, 1993.

--- The Cold War and the Color Line: American Race relations in the Global Arena. Cambridge: Harvard University Press, 2001.

Caldicott, Helen and Craig Eisendrath, War in Heaven: The Arms Race in Outer Space. New York: The New Press, 2007.

Coker, Christopher. The United States and South Africa, 1968-1985: Constructive Engagement and Its Critics. Durham: Duke University Press, 1986.

Feinstein, Charles H. An Economic History of South Africa: Conquest, Discrimination and Development. New York: Cambridge University Press, 2005.

Frankel, Glenn. Rivonia's Children: Three Families and the Cost of Conscience in White South Africa. New York: Farrar, Straus, and Giroux, 1999.

Gleijeses, Piero. Conflicting Missions: Havana, Washington, and Africa, 1959-1976. Chapel Hill: University of North Carolina Press, 2002.

Helmreich, Jonathan E. United States relations with Belgium and the Congo, 1940-1960. Cranbury: Associated University Presses, 1998.

Hull, Richard W. American Enterprise in South Africa: Historical Dimensions of Engagement and Disengagement. New York: New York University Press, 1990.

Johnson, Phyllis and David Martin, eds. Frontline Southern Africa: Destructive Engagement. New York: Four Walls Eight Windows, 1988.

Keylor, William R. The Twentieth Century World and Beyond, $5^{\text {th }}$ ed. New York: Oxford University Press, 2006. 
King Leopold's Ghost. Linden Productions, Inc. 2006.

The Kissinger Study on Southern Africa. Nottingham: Spokesman Books, 1975.

Kranz, Gene. Failure Is Not An Option. New York: Berkley Books, 2000.

Lacouture, Jean. De Gaulle: The Ruler, 1945-1970. New York: WW Norton \&Company, 1991.

Massie, Robert Kinlock. Loosing the Bonds: The United States and South Africa in the Apartheid Years. New York: Doubleday, 1997.

Matusevich, Maxim, ed. Africa in Russia, Russia in Africa: Three Centuries of Encounters. Trenton: Africa World Press, Inc., 2007.

McNamara, Francis Terry. France in Black Africa. Washington DC: National Defense University Press, 1989.

Mokoena, Kenneth, ed. South Africa and the United States: The Declassified History. New York: The New Press, 1993.

Neufeld, Michael J. The Rocket and the Reich: Peenemünde and the Coming of the Ballistic Missile Era. New York: The Free Press, 1995.

Newsom, David D. The Imperial Mantle: The United States, Decolonization, and the Third World. Bloomington: Indiana University Press, 2001.

Onslow, Sue, ed. Cold War in Southern Africa: White power, black liberation. New York: Routledge, 2009.

Payne, Richard J. The Nonsuperpowers and South Africa: Implications for U.S. Policy. Bloomington: Indiana University Press, 1990.

Polakow- Suranksy, Sasha. The Unspoken Alliance: Israel's Secret Relationship with Apartheid South Africa. New York: Pantheon Books, 2010.

Rothkopf, David J. Running the World: The Inside Story of the National Security Council and the Architects of American Power. New York: Public Affairs, 2004.

Seegers, Annette. The Military in the Making of Modern South Africa. New York: Tauris Academic Studies, 1996.

Shubin, Vladimir. The Hot "Cold War”: The USSR in Southern Africa. London: Pluto Press, 2008. 
Smith, Charles D. Palestine and the Arab-Israeli Conflict, 5th ed. Boston: Bedford/ St. Martins, 2004.

Stares, Paul B. Space and National Security. Washington, D.C.: The Brookings Institute, 1987.

Thompson, Leonard. A History of South Africa, Revised Edition. New Haven: Yale University Press, 1995.

Tsiao, Sunn. "Read You Loud and Clear!": The Story of NASA's Spaceflight Tracking and Data Network. Washington, DC: NASA History Division, 2008.

Worden, Nigel. The Making of Modern South Africa: Conquest, Segregation and Apartheid, Cambridge: Blackwell, 1994.

\section{Articles}

Copson, Raymond W. "East Africa and the Indian Ocean- A Zone of Peace?" African Affairs 76, no. 304 (Jul. 1977): 339-358.

DeVos, Christian M. "Balancing Acts: John Kennedy, The Cold War and the African National Congress.” Politikon 32, no. 1 (May 2005): 103-122.

Dickson, David A. "U.S. Foreign Policy toward Southern and Central Africa: The Kennedy and Johnson Years." Presidential Studies Quarterly 23, no. 2 (spring 1993): 301-315.

Easum, Donald B. "United States Policy toward South Africa." A Journal of Opinion 5, no. 3 (autumn 1975): 66-72.

Herbst, Jefrey. "Analyzing Apartheid: How Accurate Were US Intelligence Estimates of South Africa, 1948-1949?” African Affairs 102 (2003): 81-107.

Hoff, John. “A Revisionist View of Nixon's Foreign Policy.” Presidential Studies Quarterly 26, no. 1 (1996): 107-129.

Irwin, Ryan M. "A Wind of Change? White Redoubt and the Postcolonial Movement, 1960-1963.” Diplomatic History 33, no. 5 (Nov 2009): 897-925.

Kahn, Cynthia C. “Arms Embargo on South Africa Still An Issue.” Africa Today 15, no. 3 (Jun-Jul 1968): 5-6.

Kolodziej, Edward A. "France and the Arms Trade," International Affairs 56, no. 1 (Jan. 1980): 54-72. 
Klare, Michael and Eric Prokosch. "Evading the Embargo: How the U.S. Arms South Africa and Rhodesia." Issue: A Journal of Opinion 9, no. 1/2 (spring-summer 1979): 42-46.

Koman, Rita G. "Man on the Moon: The U.S. Space Program as a Cold War Maneuver." OAH Magazine of History 8, no. 2 (Winter 1994): 42-50.

Lockwood, Edgar. "National Security Study Memorandum 39 and the Future of United States Policy toward Southern Africa." A Journal of Opinion 4, no. 3 (autumn 1974): 63-72.

Mastny, Vojtech. “The Soviet Union's Partnership with India.” MIT Press Journals. 13 June 2011. mitpressjournals.org.

"National Security Decision Memorandum 81." Federation of American Scientists. Web. 22 March 2011.

Ogunbadejo, Oye. "Diego Garcia and Africa's Security." Third World Quarterly 4, no. 1 (Jan 1982): 104-120.

Parker, Jason. "Cold War II: The Eisenhower Administration, the Bandung Conference, and the Periodization of the Postwar Era." Diplomatic History 30, no. 7 (November 2006): 867-892.

Rich, Paul. "United States Containment Policy, South Africa, and the Apartheid Dilemma." Review of International Studies 14, no. 3 (Jul 1988): 179-194.

“The Rivonia Trial and Lilliesleaf Farm.” South Africa History Online. 3 May 2011. www.sahistory.org.za.

Spence, J.E. "Southern Africa in the Cold War." History Today 49, no. 2 (Feb 1999): 4349.

"U.N. Security Council Resolution on Arms Embargo Against South Africa." International Legal Materials 9, no. 5 (Sept 1970): 1091-1092.

Newspapers

“Excerpts From U.S. Statement on South Africa.” New York Times. 3 August 1963, pg. 6. “French-Latin Ties Seen as Aiding U.S.” New York Times. 23 February 1961, pg. 9.

“Fumbling at Cape Town.” The Times. 6 February 1967, pg. 11. 
Garrison, Lloyd. “France Increases South Africa Ties.” New York Times. 27 March 1968, pg. 7.

Johnson, Thomas A. "Call At Capetown By Ship Opposed.” New York Times. 2 February 1967, pg. 12.

Lelyveld, Joseph. "Verwoerd Race Bar Challenges U.S. at Space Tracking Stations." New York Times. 28 June 1965, pgs. 1, 8.

Martin, Douglas. "Arthur Goldreich, a Leader of the Armed Fight to End Apartheid, Dies at 82." New York Times. 27 May 2011. www.nytimes.com.

Myburgh, Tertius. "South Africa's Ruling Party, in Power 21 Years, Is Shaken By Feuds and Pressure to Widen Apartheid.” New York Times. 27 May 1969, pg. 13.

"Navy Ship Awaits U.S. Assent for Visit to Durban.” New York Times. 14 February 1967, pg. 5.

Reston, James. “Washington.” New York Times. 10 January 1964, pg. 42.

“S. Africa M.P.s Boycott U.S. Carrier.” The Times. 7 February 1967, pg. 8.

“Ship Crew Deplores Incident at Durban.” New York Times. 20 February 1967, pg. 21.

“South Africa Profile.” BBC News. 28 Oct 2011. Web. 16 Nov 2011.

“South Africa Will Give Blacks 'Homeland' Citizen Papers.” New York Times. 10 April 1968, pg. 3.

Teltsch, Kathleen. "Embargo on Arms Tightened By U.N.” New York Times. 24 July 1970, pg. 7.

“U.N. Adopts Curb on South Africa.” New York Times. 8 August 1963, pg. 1.

“U.S. Carrier Cuts Visit to Capetown.” New York Times. 6 February 1967, pg. 10.

“U.S. Carrier Expected to Leave S. Africa Today: Bitter Quarrel over Colour Bar." The Times. 6 February 1967, pgs. 1, 11.

“U.S. Halting Arms for South Africa.” New York Times. 10 October 1963, pg. 8.

“U.S. Stand on Arms Stirs South Africa.” New York Times. 5 August 1963, pg. 2.

“Was This Call Necessary?” New York Times. 5 February 1967, pg. E8. 
Welles, Benjamin. "Navy Stands Firm on Capetwon Visit: Javits and Percy Are Among Congressional Critics." New York Times. 3 February 1967, pg. 10. 


\section{Appendix A: Timeline of South African History:}

Below is a timeline of major South African events beginning with the founding of the Cape Colony at Table Bay by the Dutch East India Company to the April 1994 elections in South Africa. The timeline contains selections from the chronology as printed in The Making of Modern South Africa by Nigel Worden.

1652- Dutch East India Company establishes settlement at Cape Town

1806- British establish permanent control over Cape Colony

1828- Ordinance 49 imposes pass controls on African workers in Cape Colony

1836- Settlers leave eastern Cape ('Great Trek')

1867- Discovery of diamonds in Kimberley

1886- Gold discovered in Witwatersrand (Johannesburg)

1894- Glen Grey Act establishes a separate land and tax system for Africans (eastern cape)

1899-1902- South African ('Boer’) War: British conquest of Transvaal and Orange Free State

1903-1905- South African Native Affairs Commission recommends blueprint for segregation

1910- Union of South Africa established

1912- $\quad$ Foundation of SANNC (predecessor to ANC)

1913- $\quad$ Native Land Act segregates land ownership and restricts African land ownership to the 'native reserves' 
1923- Native (Urban Areas) Act provides for urban segregation and African influx control

1934- South African Party (under Smuts) and National Party (under Hertzog) form coalition government

1936- $\quad$ Native Trust and Land Act consolidates reserves

1950- $\quad$ Population Registration Act; Immortality Act; Group Areas Act;

Suppression of Communism Act

1951- Bantu Authorities Act

1952- Abolition of Passes and Coordination of Documents Act extends pass laws; ANC launches 'Defiance Campaign'

1953- $\quad$ Separate Amenities Act; Bantu Education Act; Criminal Law Amendment Act

1955- $\quad$ Native (Urban Areas) Amendment Act extends urban influx control

1959- $\quad$ Foundation of Pan African Congress (PAC)

1960- Sharpeville shootings and State of Emergency; Banning of ANC, Communist Party and PAC

1961- Umkhonto we Sizwe guerilla movement founded; South Africa leaves Commonwealth and becomes a republic

1964- Rivonia trials sentence ANC leaders to life imprisonment

1969- Foundation of South African Students' Organization (SASO) under Biko

1976- $\quad$ Revolt in Soweto and other townships

1977- Detention and murder of Biko; banning of Black Consciousness organizations 
1978- P.W. Botha introduces 'total strategy' policy

1984-1986- Widespread resistance; State of Emergency and troops moved into townships

1986- $\quad$ Repeal of pass laws

1989- $\quad$ Botha replaced by F.W. de Klerk

1990- De Klerk unbans ANC, PAC, and Communist Party; Nelson Mandela released from jail

1991- $\quad$ Repeal of Group Areas, Land, and Population Registration Acts; Convention for a Democratic South Africa (CODESA) formed to negotiate democratic constitution

1994- $\quad$ ANC wins first non-racial election; Mandela becomes president ${ }^{329}$

${ }^{329}$ Worden, ix-Xv. 


\section{Appendix B: Operation Mayibuye}

Operation Mayibuye- "The Return”- was a sabotage campaign designed by Umkhonto We Sizwe, the armed wing of the ANC. The idea behind this sabotage campaign was to force the white South African government to negotiate with the ANC. The six-page proposal found during a raid on the leadership of the ANC at Lilliesleaf was a complex plan that outlined a detailed process to conduct a sabotage campaign against the South African government. The plan caused a split in the ANC leadership because some members felt it was unrealistic, whereas others argued not only was it realistic, but it was already underway. ${ }^{330}$ Below is the text of Operation Mayibuye in its entirety.

\section{PART I.}

The white state has thrown overboard every pretence of rule by democratic process. Armed to the teeth it has presented the people with only one choice and that is its overthrow by force and violence. It can now truly be said that very little, if any, scope exists for the smashing of white supremacy other than by means of mass revolutionary action, the main content of which is armed resistance leading to victory by military means.

The political events which have occurred in the last few years have convinced the overwhelming majority of the people that no mass struggle which is not backed up by armed resistance and military offensive operations, can hope to make a real impact. This can be seen from the general mood of the people and their readiness to undertake even desperate and suicidal violent campaigns of the Leballo type. It can also be gauged by

\footnotetext{
${ }^{330}$ Frankel, 107-109.
} 
their reluctance to participate in orthodox political struggles in which they expose themselves to massive retaliation without a prospect of hitting back. We are confident that the masses will respond in overwhelming numbers to a lead which holds out a real possibility of successful armed struggle .

Thus two important ingredients of a revolutionary situation are present: -

a. A disillusionment with constitutional or semi-constitutional forms of struggle and a conviction that the road to victory is through force;

b. A militancy and a readiness to respond to a lead which holds out a real possibility of successful struggle.

In the light of the existence of these ingredients the prosecution of military struggle depends for its success on two further factors: -

A. The strength of the enemy. This must not be looked at statically but in the light of objective factors, which in a period of military struggle may well expose its brittleness and

B. The existence of a clear leadership with material resources at its disposal to spark off and sustain military operations.

The objective military conditions in which the movement finds itself makes the possibility of a general uprising leading to direct military struggle an unlikely one. Rather, as in Cuba, the general uprising must be sparked off by organised and well prepared guerrilla operations during the course of which the masses of the people will be drawn in and armed.

We have no illusions about the difficulties which face us in launching and successfully prosecuting guerrilla operations leading to military victory. Nor do we assume that such a 
struggle will be over swiftly. We have taken into account and carefully weighed numerous factors and we mention some of them:

a. We are faced with a powerfully armed modern state with tremendous industrial resources, which can, at least in the initial period, count on the support of three million whites. At the same time the State is isolated practically from the rest of the world, and if effective work is done, will have to rely in the main on its own resources. The very concentration of industry and power and the interdependence of the various localities operates as both an advantage and a disadvantage for the enemy. It operates as a disadvantage because effective guerrilla operations can within a relatively short period create far greater economic havoc and confusion than in a backward, decentralised country.

b. The people are unarmed and lack personnel who have been trained in all aspects of military operations. A proper organisation of the almost unlimited assistance which we can obtain from friendly Governments will counter-balance its disadvantage. In the long run a guerrilla struggle relies on the enemy for its source of supply. But in order to make this possible an initial effective arming of the first group of guerrilla bands is essential. It is also vital to place in the field persons trained in the art of war who will act as a nucleus of organisers and commanders of guerrilla operations.

c. The absence of friendly borders and long scale impregnable natural bases from which to operate are both disadvantages. But more important than these factors is the support of the people who in certain situations are better protection than mountains and forests. In the rural areas which become the main theatre of 
guerrilla operations in the initial phase, the overwhelming majority of the people will protect and safeguard the guerrillas and this fact will to some measure negative the disadvantages. In any event we must not underestimate the fact that there is terrain in many parts of South Africa, which although not classically impregnable is suitable for guerrilla type operations. Boer guerrillas with the support of their people operated in the plains of the Transvaal. Although conditions have changed there is still a lesson to be learnt from this.

Although we must prepare for a protracted war we must not lose sight of the fact that the political isolation of South Africa from the world community of nations and particularly the active hostility towards it from almost the whole of the African Continent and the Socialist world may result in such massive assistance in various forms, that the state structure will collapse far sooner than we can at the moment envisage. Direct military intervention in South West Africa, an effective economic and military boycott, even armed international action at some more advanced stage of the struggle are real possibilities which will play an important role. In no other territory where guerrilla operations have been undertaken has the international situation been such a vital factor operating against the enemy. We are not unaware that there are powerful external monopoly interests who will attempt to bolster up the white state. With effective work they can be isolated and neutralised. The events of the last few years have shown that the issue of racial discrimination cuts across world ideological conflict albeit that the West proceeds from opportunistic premises.

The following plan envisages a process which will place in the field, at a date fixed now, simultaneously in pre-selected areas armed and trained guerrilla bands who will find 
ready to join the local guerrilla bands with arms and equipment at their disposal. It will further coincide with a massive propaganda campaign both inside and outside South Africa and a general call for unprecedented mass struggle throughout the land, both violent and non-violent. In the initial period when for a short while the military adv. [sic] will be ours the plan envisages a massive onslaught on pre-selected targets which will create maximum havoc and confusion in the enemy camp and which will inject into the masses of the people and other friendly forces a feeling of confidence that here at least is an army of liberation equipped and capable of leading them to victory. In this period the cornerstone of guerrilla operations is "shamelessly attack the weak and shamelessly flee from the strong".

We are convinced that this plan is capable of fulfillment. But only if the whole apparatus of the movement both here and abroad is mobilised for its implementation and if every member now prepares to make unlimited sacrifice for the achievement of our goal. The time for small thinking is over because history leaves us no choice.

\section{PART II.}

AREAS.

1. Port Elizabeth - Mzimkulu.

2. Port Shepstone - Swaziland.

3. North Western Transvaal, bordering respectively Bechuanaland \& Limpopo.

4. North Western Cape - South West.

\section{PART III.}


PLAN.

1. Simultaneous landing of 4 groups of 30 based on our present resources whether by ship or air - armed and properly equipped in such a way as to be self sufficient in every respect for at least a month.

2. At the initial stages it is proposed that the 30 are split up into platoons of 10 each to operate more or less within a contiguous area and linking their activities with pre-arranged local groups.

3. Simultaneously with the landing of the groups of 30 and thereafter, there should be a supply of arms and other war material to arm the local populations which become integrated with the guerrilla units.

4. On landing, a detailed plan of attack on pre-selected targets with a view to taking the enemy by surprise, creating the maximum impact on the populace, creating as much chaos and confusion for the enemy as possible.

5. Choice of suitable areas will be based on the nature of the terrain, with a view to establishing base areas from which our units can attack and to which they can retreat.

6. Before these operations take place political authority will have been set up in secrecy in a friendly territory with a view to supervising the struggle both in its internal and external aspects. It is visualised that this authority will in due course of time develop into a Provisional Revolutionary Government . 7. This Political Authority should trim its machinery so that simultaneously with the commencement of operations it will throw out massive propaganda to win world support for our struggle, more particularly: - 
a. A complete enforcement of boycott,

b. Enlisting the support of the international trade union movement to refuse handling war materials and other goods intended for the South African Government,

c. Raising a storm at the United Nations which should be urged to intervene militarily in South West Africa.

d. Raising of large scale credits for the prosecution of the struggle

e. Arranging for radio facilities for daily transmission to the world and to the people of South Africa.

f. If possible the Political Authority should arrange for the initial onslaught to bombard the country or certain areas with a flood of leaflets by plane announcing the commencement of our armed struggle as well as our aims, and calling upon the population to rise against the Government.

g. Stepping up transport plans, e.g. a weekly or bi weekly airlift of trainees outside the country in order to maintain a regular, if small flow of trained personnel.

h. In order to facilitate the implementation of the military aspect of the plan it is proposed the National High Command appoint personnel to be quartered at Dar under the auspices of the office there.

\section{PART IV.}

INTERNAL ORGANISATION. 
In preparation for the commencement of operations when our external team lands, intensive as well as extensive work will have been done. For instance, guerrilla units will have been set up in the main areas mapped out in Part I above as well as in the other areas away from the immediate scene of operation.

Progressively sabotage activity throughout the country will be stepped up before these operations. Political pressure too, in the meanwhile will be stepped up in conjunction with the sabotage activity.

In furtherance of the general ideas set out above the plan for internal organisation is along the following pattern: -

1. Our target is that on arrival the external force should find at least 7,000 men in the four main areas ready to join the guerrilla army in the initial onslaught. Those will be allocated as follows: -
a. Eastern Cape - Transkei 2,000
b. Natal - Zululand 2,000
c. North Western Transvaal 2,000
d. North-Western Cape 1,000

2. To realise our target in each of the main areas it is proposed that each of the four areas should have an overall command whose task it will be to divide its area into regions, which in turn will be allocated a figure in proportion to their relative importance.

3. The preparation for equipping the initial force envisaged in I above will take place in three stages, thus:

a. By importation of Military supply at two levels: 
i. Build up of firearms, ammunition and explosives by maintaining a regular flow over a period of time.

ii. By landing additional [supplies] simultaneously with the arrival of our external force.

b. Acquisition and accumulation internally of firearms, ammunition and explosives at all levels of our organisation.

c. Collection and accumulation of other military such as food, medicines, communication equipment etc.

4. It is proposed that auxiliary guerrilla/sabotage units in the four main areas be set up before and after the commencement of operations. They may engage in activities that may serve to disperse the enemy forces, assist to maintain the fighting ability of the guerrillas as well as draw in the masses in support of the guerrillas.

5. It is proposed that in areas falling outside the four main guerrilla areas MK units should be set up to act in support of the activities in the guerrilla areas, and to harass the enemy.

6. In order to draw in the masses of the population the political wing should arouse the people to participate in the struggles that are designed to create an upheaval throughout the country.

\section{PART V.}

\section{DETAILED PLAN OF IMPLEMENTATION.}


In order to implement the plans set out above in Parts I to 111 we establish Departments which are to be charged with duties to study and submit detailed reports and plans in respect of each of their Departments with the following terms of reference: -

\section{Intelligence Department}

This Committee will be required to study and report on the following: -

a. The exact extent of each area

b. The portions of the country that are naturally suited for our operations and their location within each area.

c. Points along the coast which would be suitable for landing of men and supplies and how these are going to be transferred from the point of landing to the area of operations.

d. The situation of enemy forces in each area, thus: -

i. the military and the police as well as their strength

ii. military and police camps, and towns, and the distances between them,

iii. system of all forms of communication in the area,

iv. the location of trading stations and chiefs and headmen's kraals.

v. air fields and air strips in the areas.

e. Selection of targets to be tackled in initial phase of guerrilla operations with a view to causing maximum damage to the enemy as well as preventing the quick deployment of reinforcements.

In its study the Committee should bear in mind the following main targets: -

i. strategic road, railways and other communications

ii. power stations 
iii. police, stations, camps and military forces

iv. irredeemable Government stooges.

f. A study of climatic conditions in relation to seasons, as well as diseases common to the area.

g. The population distribution in the areas as well as the main crops.

h. Rivers and dams.

i. And generally all other relevant matters

2. External Planning Committee which shall be charged with the following tasks: -

a. Obtaining of arms, ammunition and explosives and other equipment

b. In co-operation with our internal machinery, making arrangements for the despatch of items in I above into the country

c. Obtaining of transport by land, sea and air for the landing of our task force and for the continued supply of military equipment.

\section{Political Authority}

We make a strong recommendation that the joint sponsoring organisations should immediately set about creating a political machinery for the direction of the revolutionary struggle as set out in Nos. 6,7 and 8 of Part 11 and to set up a special committee to direct guerrilla political education.

\section{Transport Committee.}

This Committee is assigned the following duties: -

a. The organisation of transport facilities for our trainees

b. To organise transport for the re entry of our trainees

c. To undertake any transport duties assigned to them from time to time . 


\section{Logistics Department - Technical and Supply Committee}

Its Functions are: -

a. To manufacture and build up a stock of arms, ammunition from internal sources.

b. To organise reception, distribution and storage of supplies from external sources.

c. To organise the training of personnel in the use of equipment referred to in (a) and (b) above.

d. Obtaining of all other relevant supplies necessary to prosecute an armed struggle, to wit, inter alia, medical supplies, clothing, food, etc., and the storage of these at strategic points.

e. Acquiring equipment to facilitate communications.

f. To undertake all duties and functions that fall under the Department of Logistics.

\section{PART VI}

\section{MISCELLANEOUS}

1. Immediate Duties of the National High Command in Relation to the Guerilla Areas:

a. To map out regions in each area with a view to organising Regional and District Commands and NK [sic] units.

b. To achieve this we strongly recommend the employment of 10 full time organisers in each area.

c. The organisers shall be directly responsible to the National High Command .

d. The NHC is directed to recruit and arrange for the external training of at least 300 men in the next two months.

\section{Personal}


a. Intelligence Alex Secundus Otto

b. External Planning Committee Johnson, Thabo and Joseph together with a senior ANC rep. as well as co-opted personnel, seconded to us by friendly Govts.

c. Transport Committee Percy secundus Nbata.

d. Logistics Dept. Bri-bri secundus Frank

\section{Special Directives to Heads of Departments.}

The Heads of Departments are required to submit not later than the 30th May, 1963, plans detailing: -

a. The structural organisation of their Department

b. The type and number of personnel they require to be allocated to them and their duties and functions.

c. The funds required for their work both for immediate and long term purposes.

d. Schedule of time required to enable them to fulfill given targets and what these are.

e. Other matters relating to the efficient execution of the Departments Plans. 4. Organisation of Areas. Organisers and Setting up of proper Machinery Rethau and James for this task ${ }^{331}$

331 “Operation Mayibuye,” The Rivonia Trial, 3 May 2011. http://law2.umkc.edu/faculty/projects/ftrials/mandela/mandelahome.html. 